JULIANA BARBOSA GOULARDINS

\title{
Perfil psicomotor de crianças com transtorno de déficit de atenção / hiperatividade do tipo combinado
}

Dissertação apresentada à Faculdade de Medicina da Universidade de São Paulo para obtenção do título de Mestre em Ciências

Programa de: Pediatria

Orientador: Erasmo Barbante Casella

SÃO PAULO

2010 
Dados Internacionais de Catalogação na Publicação (CIP)

Preparada pela Biblioteca da

Faculdade de Medicina da Universidade de São Paulo

Creprodução autorizada pelo autor

\section{Goulardins, Juliana Barbosa}

Perfil psicomotor de crianças com transtorno de déficit de atenção / hiperatividade do tipo combinado / Juliana Barbosa Goulardins. -- São Paulo, 2010.

Dissertação (mestrado)--Faculdade de Medicina da Universidade de São Paulo.

Programa de Pediatria.

Orientador: Erasmo Barbante Casella .

Descritores: 1.Transtorno do déficit de atenção com hiperatividade 2.Desenvolvimento infantil 3.Destreza motora 4.Criança 
Aos meus pais Eduardo Goulardins Neto e Maria de Fátima Barbosa Goulardins. 


\section{AGRADECIMENTOS}

Agradeço, primeiramente, a Deus que me guia em todos os passos e transforma minha vida com seu amor.

Aos meus pais, que sempre me dedicam seus esforços e seu amor.

Ao meu orientador Prof. Dr. Erasmo Barbante Casella, que colaborou para a realização deste $e$ de outros trabalhos, transmitindo-me conhecimentos e suas vivências.

Às crianças e seus pais, que participaram deste estudo, pela colaboração, contribuindo para meu crescimento e amadurecimento profissional, sem as quais não seria possível a realização deste trabalho.

À Juliana Bilhar e sua mãe Janete Bilhar que acompanharam minha trajetória e participaram direta ou indiretamente desta pesquisa. Vocês me ajudaram muito, não só na formação profissional, mas principalmente pessoal e agora agradeço com todo o carinho.

Enfim, a todas as pessoas que de alguma maneira me ajudaram no decorrer desse caminho... Maria Cecília Periotto, Sandra Pasquale Pacheco, às professoras e às escolas estaduais Keizo Ishihara e Eduardo Carlos Pereira.

Talvez um muito obrigada seja pouco, mas que esta forma de homenagem sirva para demonstrar meus eternos agradecimentos. 
"Sê todo em cada coisa.

Põe quanto és

No mínimo que fazes."

(Fernando Pessoa) 
Lista de abreviaturas e siglas

Lista de gráficos

Lista de tabelas

Resumo

Summary

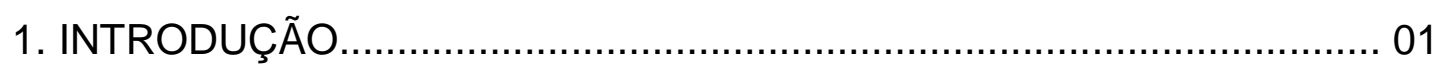

1.1 Transtorno de déficit de atenção e hiperatividade ............................. 01

1.2 Quadro clínico ............................................................................ 02

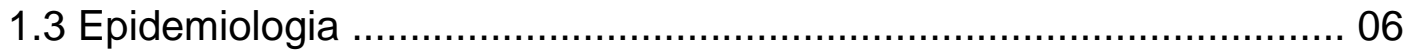

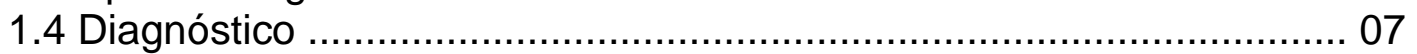

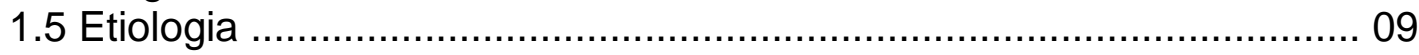

1.6 Neurobiologia ..................................................................... 12

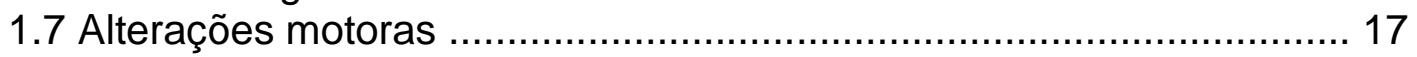

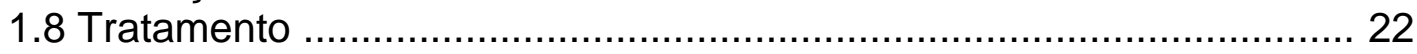

1.9 Avaliação do desenvolvimento infantil........................................ 26

1.10 Habilidades psicomotoras........................................................ 32

2. OBJETIVOS

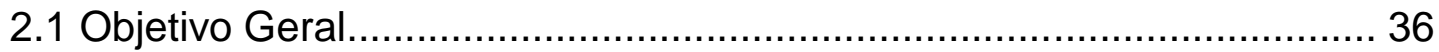

2.2 Objetivos Específicos............................................................. 36

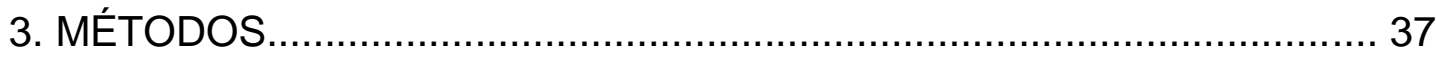

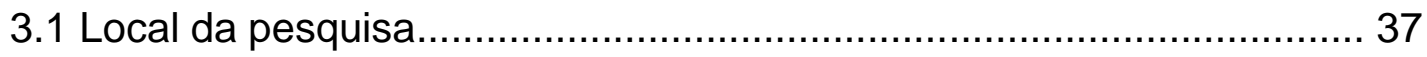

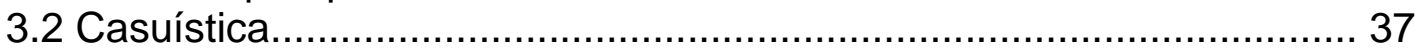

3.2.2 Cálculo da Amostra............................................................ 37

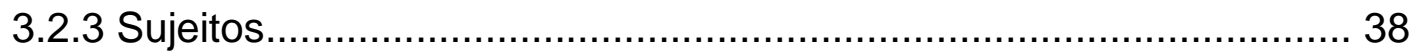

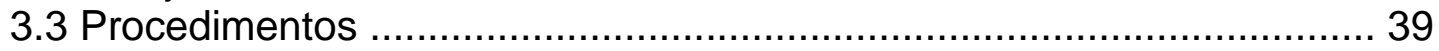

3.4 Análise Estatística...................................................................... 41

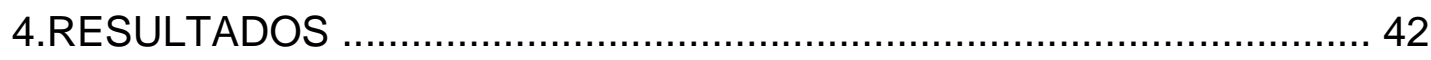

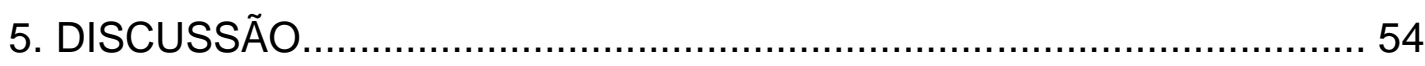

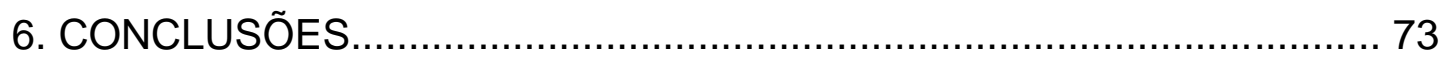

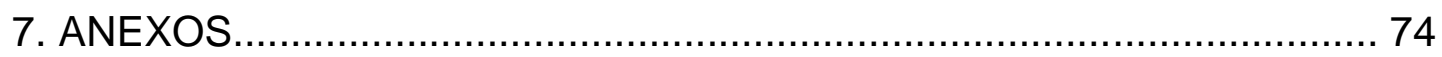

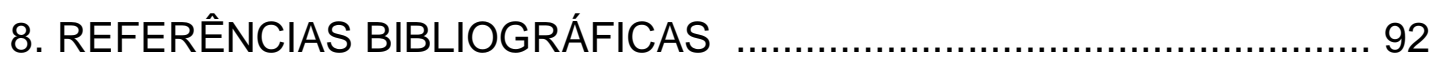




\title{
LISTAS DE ABREVIATURAS E SIGLAS
}

\author{
APA - American Psychiatric Association
}

CREFSP - Conselho Regional de Educação Física de São Paulo

CREFITO - Conselho Regional de Fisioterapia e Terapia Ocupacional

DSM-IV-TR - Diagnostic and Statistical Manual of Mental Disorders, Fourth

edition, Text Revision

EDM - Escala de Desenvolvimento Motor

FEs - Funções Executivas

C1- Classificação do desenvolvimento da motricidade fina

C2 - Classificação do desenvolvimento da motricidade global

C3 - Classificação do desenvolvimento do equilíbrio

C4 - Classificação do desenvolvimento do esquema corporal

C5 - Classificação do desenvolvimento da organização espacial

C6 - Classificação do desenvolvimento da organização temporal

IC - Idade cronológica

IM1 - Idade motora da motricidade fina

IM2 - Idade motora da motricidade global

IM3 - Idade motora do equilíbrio

IM4 - Idade motora do esquema corporal

IM5 - Idade motora da organização espacial

IM6 - Idade motora da organização temporal

IMG - Idade motora geral

OMS - Organização Mundial de Saúde

OPAS - Organização Pan Americana de Saúde

QMG - Quociente motor geral

SNAP - Swanson, Nolan and Pelham (SNAP) Questionnaire

TC - Transtorno de conduta

TDAH - Transtorno de déficit de atenção / hiperatividade

TDO - Transtorno desafiador opositivo 


\section{LISTA DE GRÁFICOS}

Gráfico 1 - Distribuição da classificação do desenvolvimento do grupo caso

Gráfico 2 - Distribuição da classificação do desenvolvimento. 43 do grupo controle

Gráfico 3 - Diferença entre a idade motora geral e a 49 idade cronológica de cada indivíduo

Gráfico 4 - Desempenho da motricidade fina 50

Gráfico 5 - Desempenho da motricidade global....................................... 51

Gráfico 6 - Desempenho do equilíbrio ................................................. 51

Gráfico 7 - Desempenho do esquema corporal .....................................52

Gráfico 8 - Desempenho da organização espacial ................................... 52

Gráfico 9 - Desempenho da organização temporal ................................... 53

Gráfico 10 - Desempenho da idade motora geral ..................................... 53 


\section{LISTA DE TABELAS}

Tabela 1 - Classificação dos resultados da EDM ............................... 31

Tabela 2 - Classificação do Desenvolvimento Motor e Pontuação ............. 45

Tabela 3 - Distribuição das habilidades psicomotoras ...........................46

Tabela 4 - Comparação entre os grupos ........................................... 48 


\section{RESUMO}

Goulardins JB. Perfil psicomotor de crianças com transtorno de déficit de atenção / hiperatividade do tipo combinado. [dissertação]. São Paulo: Faculdade de Medicina, Universidade de São Paulo; 2010.

O transtorno de déficit de atenção/ hiperatividade (TDAH) é o distúrbio neurocomportamental mais comum na população pediátrica e, a habilidade psicomotora dessas crianças pode ser significativamente mais baixa do que se espera em cerca de $30 \%$ a $50 \%$ dos casos. O objetivo desse estudo foi traçar o perfil psicomotor de crianças com TDAH do tipo combinado. O grupo caso foi formado por 34 pacientes acompanhados nos ambulatórios de Neurologia Infantil do Instituto Central e de Distúrbios do Aprendizado do Instituto da Criança do Hospital das Clínicas da Faculdade de Medicina da Universidade de São Paulo, que apresentavam idade entre sete e 11 anos, sexo masculino, diagnóstico de TDAH tipo combinado, sem comorbidades (exceto o transtorno desafiador opositivo) e sem terem iniciado tratamento. O grupo controle foi composto de 32 escolares da rede pública do município de São Paulo e seguiu os mesmos critérios de inclusão em relação à idade e sexo. A avaliação foi feita por meio da Escala de Desenvolvimento Motor, descrita por Rosa Neto, na qual foram utilizados todos os testes propostos: motricidade fina, motricidade global, equilíbrio, esquema corporal, organização espacial e temporal. Todos os testes foram aplicados em uma única sessão, com tempo médio de 40 minutos. Para a análise estatística foi utilizado o pacote estatístico Stata versão 11.0 (Stata Corporation, College 
Station, TX, E.U.A.) e empregados os testes Shapiro-Wilks, teste $t$ de Student, teste $U$ de Mann-Whitnney. Os resultados demonstraram que os quocientes motores de todas as áreas estudadas foram mais baixos no grupo caso que no grupo controle, apesar de em sua maioria representarem valores normais segundo a escala (53\% apresentaram desenvolvimento normal médio, $29 \%$ normal baixo, $9 \%$ muito inferior, $6 \%$ normal alto e $3 \%$ inferior). A maioria das crianças com TDAH (88,3\%) atingiu idades negativas (média -12,8 meses), através da diferença da idade motora geral e a idade cronológica. Nos indivíduos saudáveis, a idade negativa média foi igual a $-3,9$ meses e ocorreu em $53,1 \%$ da amostra. Houve diferenças estatisticamente significantes entre os grupos quanto à idade motora geral $(p=0,004)$, quociente motor geral $(p<0,001)$, equilíbrio $(p=0,008)$, organização espacial $(p<0,001)$, motricidade fina $(p=0,009)$ e global $(p=0,008)$. Assim, foi possível verificar dificuldades no desempenho psicomotor de crianças com TDAH do tipo combinado. O conhecimento sobre o perfil psicomotor dessas crianças pode auxiliar na definição das propostas terapêuticas, a fim de minimizar os prejuízos em sua qualidade de vida.

Descritores: 1.Transtorno do déficit de atenção com hiperatividade 2.Desenvolvimento infantil 3.Destreza motora 4.Criança 


\section{SUMMARY}

Goulardins JB. Psychomotor Profile of Children with attention deficit hyperactivity disorder combined type. [dissertation]. Faculty of Medicine, University of Sao Paulo, SP (Brazil); 2010.

The attention deficit hyperactivity disorder (ADHD) is the most common neurobehavioral disorder in children and the psychomotor skill of these children may be significantly lower than expected by about $30 \%$ to $50 \%$ of cases. The aim of this study was to determine the psychomotor profile of children with ADHD combined type. The case group consisted of 34 patients followed in outpatient clinics of the Child Neurology of Central Institute and Learning Disorders of Children's Institute of Clinic's Hospital of the Faculty of Medicine of University of São Paulo, who were aged between seven and 11 years, sex male, diagnosis for ADHD combined type, without comorbidity (except oppositional defiant disorder) and had not begun treatment. The control group was composed of 32 scholars from public schools in São Paulo and followed the same inclusion criteria regarding age and sex. The evaluation was made through the Motor Development Scale, described by Rosa Neto, which were used in all tests available: fine motricity, gross motricity, balance, body scheme, spatial and temporal organization. All tests were applied in one session, wtith medium time of 40 minutes. For the statistical analysis used Stata software version 11.0 (Stata Corporation, College Station, TX, USA) and used the Shapiro-Wilks tests, Student t test, Mann-U Whitnney test. The results showed that the ratios engines all areas 
studied were lower in case group than the control group, although in most cases represent normal values according to scale (53\% were classified as "normal medium" motor development, 29\% "normal low", 9\% "very low", $6 \%$ "normal high" and 3\% "lower"). Most children with ADHD (88.3\%) achieved negative ages (average -12.8 months) by age difference genreal motor age and chronological age. In healthy subjects, the average of negative age was equal to -3.9 months and occurred in $53.1 \%$ of the sample. Statistically significant differences between groups in general motor age $(p=0.004)$, general motor quotient $(p<0.001)$, balance $(p=0.008)$, spatial organization $(p<0.001)$, fine motricity $(p=0.009)$ and gross motricity $(p=0.008)$. Thus, it was possible observed problems in psychomotor performance of children with ADHD combined type. Knowledge about the psychomotor profile of these children may assist in determining treatment proposals in order to minimize losses in their quality of life.

Key word: 1. Attention deficit disorder with hyperactivity. 2. Child development. 3. Motor Dexterity 4. Child 


\section{INTRODUÇÃO}

\subsection{Transtorno de déficit de atenção e hiperatividade}

O transtorno de déficit de atenção e hiperatividade (TDAH) é uma desordem neurobiológica, cuja característica principal é um padrão persistente de desatenção e/ou hiperatividade, mais frequente e grave do que o tipicamente observado em indivíduos no mesmo nível de desenvolvimento (APA, 2000; Barkley, 2002).

As primeiras referências à hiperatividade e desatenção na literatura não médica datam da metade do século XIX, quando ocorreu a publicação do livro de Henrich Hoffman com histórias mostrando um comportamento infantil inadequado (Hoffman, 1854). A hiperatividade em crianças foi clinicamente descrita pela primeira vez em um jornal médico (Lancet) em 1902 por George Still (Still, 1902).

Esse transtorno comportamental aparece com diferentes nomenclaturas no decorrer da história, incluindo algumas denominações como "Lesão Cerebral Mínima", "Reação Hipercinética da Infância", "Distúrbio do Déficit de Atenção", "Distúrbio de Hiperatividade com Déficit de Atenção", "Transtornos Hipercinéticos", e "Transtorno do Déficit de Atenção/Hiperatividade" (Rohde e Halpern, 2004; Cormier, 2008).

Atualmente, os sistemas classificatórios de doenças, a Classificação Estatística Internacional de Doenças e Problemas Relacionados à Saúde décima edição (CID-10) e o Manual de Diagnóstico e Estatística das 
Perturbações Mentais - quarta edição revisada (DSM IV TR), utilizam nomenclaturas diferentes, transtornos hipercinéticos e TDAH respectivamente, mas apresentam muitas similaridades diagnósticas para 0 transtorno (OMS, 1993; APA, 2000).

Embora ainda existam alguns embates sobre o diagnóstico de TDAH em certos meios, as evidências na literatura científica demonstram sua validade como um transtorno genuíno, definido por sintomas de desatenção, hiperatividade e impulsividade, que são inapropriados para idade, excessivos, causando prejuízos, não ocorrendo em um único contexto e não podendo ser atribuídos a outro diagnóstico (APA, 2000; Barkley, 2003).

\subsection{Quadro clínico}

O TDAH consiste em um distúrbio neurocomportamental caracterizado por desatenção e hiperatividade/ impulsividade que, frequentemente resulta em prejuízo funcional substancial (Visser e Lesesne, 2003; Louzã Neto, 2010).

Dessa forma, o DSM-IV TR subdivide o TDAH em três tipos: TDAH com predomínio de sintomas de desatenção, TDAH com predomínio de sintomas de hiperatividade/ impulsividade e TDAH combinado (APA, 2000; Rohde et al, 2000; Rohde e Halpern, 2004).

A atenção é a capacidade de manter o foco em um estímulo ou atividade particular e assim, corresponde a um conjunto de processos que 
leva à seleção ou priorização no processamento de certas categorias de informação (Helene e Xavier, 2003; Lundy-Ekman, 2008).

A capacidade de processar a informação pode ser medida através do tempo de reação, que é o período de tempo entre o surgimento do estímulo alvo e da resposta motora correta do sujeito. Menores tempos de reação são interpretados como decorrentes de maior grau de atenção do indivíduo para o local ou a natureza do estímulo-alvo (Lent, 2010; Bolfer et al, 2010).

Nesse sentido, a desatenção é a capacidade limitada de permanecer atento por um tempo necessário para realizar ou compreender determinada tarefa (Barkley, 2003). Os indivíduos com TDAH têm problemas no sistema atencional e apresentam maior tempo de reação para respostas corretas do que indivíduos sem o transtorno, o que sugere maior lentidão, menor atenção para a tarefa com a perda progressiva de atenção sustentada e prontidão de resposta, ou seja, capacidade reduzida de processamento da informação (Bolfer et al, 2010).

O TDAH com predomínio dos sintomas de desatenção pode ser identificado pelas seguintes manifestações: dificuldade de prestar atenção a detalhes; errar por descuido em atividades escolares; dificuldade de manter atenção em atividades lúdicas; a criança parece não escutar quando falam com ela; não seguir instruções; não terminar tarefas escolares e/ou domésticas; dificuldade de organização; evitar envolver-se em atividades que exijam esforço mental constante; distrair-se facilmente por estímulos alheios ao que está executando; apresentar esquecimentos em suas atividades diárias; entre outras (APA, 2000; Barkley, 2002). A desatenção 
pode manifestar-se em situações escolares, profissionais ou sociais no TDAH e é comum a mudança de foco com muita facilidade, pois há uma sensibilidade excessiva aos estímulos (Louzã Neto, 2010).

O grau de atividade de um indivíduo caracteriza-se por seu comportamento motor e mental, que pode ser adequado para a idade e a circunstância ambiental, ou não. Quando a atividade motora e mental é inadequada e excessiva, denomina-se de hiperatividade (Araújo, 2002).

A hiperatividade caracteriza-se pelo excesso de atividade motora (Barkley, 2003). Como característica marcante distingue a criança por estar em constante movimentação corporal, parece não ter domínio sobre seu corpo, suas ações sugerem um desencontro entre o pensar e o agir (Antony e Ribeiro, 2004). A criança com TDAH, mesmo em ambientes estruturados, tem capacidade de redução de atividade inferior à criança saudável (Louzã Neto, 2010).

A impulsividade foi definida como tomada de decisão sem a consideração de todas as implicações de cada aspecto da situação e as possíveis consequências do comportamento (Araújo, Malloy-Diniz e Rocha, 2009). Esse sintoma manifesta-se por reações impensadas e repentinas, indivíduos impulsivos tendem a mostrar falta de antevisão das consequências de suas ações (Renner e Anderle, 2000; Barkley, 2003).

Algumas características do conjunto hiperatividade/ impulsividade, que no caso do TDAH devem ser frequentes, ocorrer em mais de um local e prejudicar a vida do portador: levantar-se com frequência da cadeira da sala de aula; agir antes de pensar, dificuldade de esperar a vez, responder a 
perguntas antes que estas estejam concluídas, correr exageradamente ou subir em móveis em situações inadequadas, fazer movimentos com as mãos ou pernas quando sentado, falar excessivamente, entre outras (APA, 2000; Barkley, 2002).

O tipo combinado pode apresentar sintomas associados de desatenção e hiperatividade / impulsividade, apresentando um maior prejuízo no funcionamento global, quando comparados aos outros grupos (Rohde et al., 2000; Rohde e Halpern, 2004).

As crianças com TDAH podem apresentar algumas características associadas ao transtorno, que variam dependendo da idade e do estágio evolutivo e podem incluir: baixa tolerância à frustração, acessos de raiva, teimosia, insistência excessiva e frequente para que suas solicitações sejam atendidas, instabilidade do humor, desmoralização, disforia, rejeição por seus pares e baixa auto-estima (APA, 2000).

Qualquer que seja o tipo desenvolvido, os indivíduos que apresentam este conjunto de sintomas têm maior comprometimento nas esferas acadêmica, social, familiar, profissional e também têm maior incidência de comorbidades. Hoje é bem estabelecido que o TDAH esteja geralmente associado à presença de um ou mais transtornos psiquiátricos e que estes problemas são pelo menos tão importantes quanto o próprio TDAH no prognóstico de cada criança (Gillberg et al, 2004, Cormier, 2008). Cerca de $60 \%$ das crianças em idade escolar encaminhadas para tratamento apresentam distúrbios psiquiátricos comórbidos (Pastura, Mattos e Araújo, 2007). 
Entre as comorbidades mais comuns estão os transtornos disruptivos do comportamento: transtorno de conduta (TC) e transtorno desafiador opositivo (TDO) (Rohde e Halpern, 2004). Outros diagnósticos frequentes são a depressão, os transtornos de ansiedade e os transtornos do aprendizado.

\subsection{Epidemiologia}

O TDAH é o transtorno neurocomportamental mais comum na população pediátrica. Estima-se, em estudos nacionais e internacionais, que $3 \%$ a $6 \%$ das crianças em idade escolar apresentem TDAH, porém a prevalência se modifica de acordo com os critérios diagnósticos utilizados e o tipo de amostra estudada (Rohde et al, 2000; Faraone et al, 2003; Pastura, Mattos e Araújo, 2007).

A estimativa global da prevalência mundial de $5,29 \%$ foi verificada em metanálise recente (Polanczyk, 2007). Estudos nacionais nos municípios de Porto Alegre e Rio de Janeiro encontraram valores estimados em 5,8\% e 8,6\% respectivamente (Rohde et al, 1999; Pastura, Mattos e Araújo, 2007).

Esse transtorno parece ser mais frequente no sexo masculino, com razões que variam de 9:1 em estudos clínicos e até 2:1 em estudos populacionais, fato que provavelmente é explicado pelo predomínio de sintomas de desatenção no sexo feminino, determinando uma diminuição dos encaminhamentos por não incomodar a família ou a escola (Amaral e Guerreiro, 2001; Rohde e Halpern, 2004). 
O tipo combinado parece ser o mais prevalente. Rohde et al (1999) observaram uma prevalência de 52,2\% para o tipo combinado, 34,8\% para o tipo desatento e $13 \%$ para o tipo hiperativo em uma amostra de adolescentes portadores de TDAH em escolas de Porto Alegre.

Cerca de $60 \%$ das crianças acometidas seguirão com o diagnóstico na idade adulta, determinando uma prevalência nessa faixa etária ao redor de 3-4 \% (Faraone, 2000; Faraone, Biederman e Mick, 2006; Fayyad et al, 2007).

Estima-se que aproximadamente duas em cada três crianças com TDAH apresentem sintomas correspondentes aos critérios do DSM-IV TR para um ou mais diagnósticos (Cormier, 2008). Há alta prevalência de comorbidades no TDAH, os TC e TDO aparecem em $30 \%$ a $50 \%$ dos casos, a depressão em $15 \%$ a $20 \%$, os transtornos de ansiedade em torno de $25 \%$ e os transtornos da aprendizagem de $10 \%$ a $25 \%$ (Rohde e Halpern, 2004).

\subsection{Diagnóstico}

A tríade sintomatológica (desatenção, hiperatividade, impulsividade) muitas vezes é verificada apenas após o ingresso escolar, pois neste período as dificuldades são percebidas pelos professores por meio da comparação com outras crianças da mesma idade e ambiente (Poeta e Rosa Neto, 2004). Dessa forma, o diagnóstico é geralmente feito na faixa etária escolar, pois nesta época os sintomas impedem que a criança se mantenha em condições favoráveis ao aprendizado, gerando problemas 
secundários antes não perceptíveis ou pouco valorizados (Pereira, Araújo e Mattos, 2005).

Os pais começam a preocupar-se com o déficit de atenção, hiperatividade/ impulsividade entre os três e quatro anos de idade (Campbell e Ewing, 1990; Grillo e Silva, 2004), porém é difícil estabelecer o diagnóstico em crianças pequenas, pois fronteiras entre os padrões normais e anormais de comportamento nessa faixa etária são muito próximas e podem ser influenciadas por fatores ambientais (Grillo e Silva, 2004).

Trata-se de um diagnóstico dimensional, no qual o número e a intensidade dos sintomas apresentados devem ser maiores do que o encontrado na população geral (Mattos et al, 2006). O prejuízo devido aos sintomas deve estar presente em pelo menos dois contextos, deve haver claras evidências de interferência no funcionamento social, acadêmico ou ocupacional apropriado em termos evolutivos (APA, 2000).

O diagnóstico do TDAH é clínico, baseado nos sinais e sintomas, por isso sua busca deve ser efetuada em várias fontes de informação incluindo o paciente, a família e a escola. Como ainda não há marcadores biológicos para o transtorno, deve-se envolver uma avaliação cuidadosa e rigor na utilização dos critérios (Remschimidt, Global ADHD Working Group, 2005).

A contextualização dos sintomas na história de vida da criança é necessária para a conclusão do diagnóstico. A duração dos sintomas de desatenção, hiperatividade / impulsividade, sua frequência e intensidade, sua persistência em vários locais e ao longo do tempo, seu prejuízo 
clinicamente significativo e o entendimento de cada um dos sintomas devem ser considerados (Rohde e Halpern, 2004).

Nesse sentido, o instrumento SNAP-IV foi desenvolvido para avaliação de manifestações do TDAH em crianças e adolescentes. É um questionário de domínio público, validado no Brasil por Mattos e colaboradores em 2006 e emprega os sintomas listados no DSM-IV TR para o TDAH e o TDO. Foi precedido pelos questionários SNAP-III e SNAP-IIIR, estes dois últimos formulados a partir da terceira versão do DSM e de sua revisão, respectivamente, todos utilizando uma escala de quatro níveis de gravidade (Swanson, 1992; DuPaul et al, 1998; Mattos et al, 2006).

O SNAP-IV possui opções de resposta para cada item avaliado, com sua respectiva pontuação: nem um pouco = zero, um pouco $=$ um, bastante $=$ dois, demais $=3$. Os escores das subescalas (desatenção, hiperatividade/ impulsividade e TDO) são calculados pela soma da pontuação de cada item divida pelo total de itens na subescala.

\subsection{Etiologia}

A etiologia do TDAH parece ser condicionada por uma vulnerabilidade genética e adversidades ambientais, assim a apresentação fenotípica depende da interação gene-ambiente. Estudos familiares, de adoção e de gêmeos têm sugerido de forma consistente uma alta participação da genética na causa do transtorno (Faraone, 2000). 
O TDAH é melhor compreendido como um transtorno poligênico, ou seja, vários genes de pequeno efeito determinam a suscetibilidade genética do transtorno. Na busca de genes de suscetibilidade e/ou modificadores do TDAH, as estratégias utilizadas são a investigação de genes candidatos baseada nas hipóteses neurobiológicas e varreduras genômicas (Roman, Rohde e Hutz, 2009).

O gene do receptor D4 de dopamina (DRD4), que é um neurotransmissor presente em regiões pré-frontais, é intensamente investigado no TDAH por sua associação ao controle inibitório e funções executivas (FEs) (Biederman e Faraone, 2005). Fatores genéticos certamente desempenham um papel na alteração da sequencia do desenvolvimento de ativação e desativação de genes que esculpem a arquitetura cortical, levando a um atraso na maturação dessas estruturas no TDAH. Neste contexto, as neurotrofinas, essenciais para a proliferação, diferenciação e sobrevivência de células neuronais e não-neuronais, surgem como candidatas promissoras (Shaw et al, 2007).

As variações clínicas do TDAH estão associadas aos processos biológicos implicados na origem de seus sintomas. Os mediadores bioquímicos mais implicados neste processo, em seus diferentes níveis sinápticos, são a dopamina e a noradrenalina, e em muito menor proporção a serotonina (Bush, Valera e Seidman, 2005; Makris et al, 2007). Genes catecolaminérgicos, do sistema noradrenérgico e serotoninérgicos também são investigados (Faraone e Khan, 2006; Mick e Faraone, 2008). Vários genes de pequeno efeito podem ser responsáveis por uma suscetibilidade 
genética ao transtorno, à qual se somam diferentes agentes ambientais (Rohde e Halpern, 2004). Mas, nenhum polimorfismo isolado em um gene ou combinações de genes têm valor preditivo positivo suficiente para o diagnóstico de TDAH atualmente.

Entre os fatores ambientais encontramos a exposição materna ao tabaco, álcool, estresse e cafeína durante a gravidez (Rohde e Halpern, 2004). O fumo na gestação classicamente tem sido considerado como o fator não genético mais relacionado ao TDAH, sendo apontada uma razão de chance cerca de quatro vezes maior do aparecimento de TDAH em filhos de mães fumantes, quando comparadas às não fumantes (Schmitz et al, 2006).

No entanto, em um estudo prospectivo recente, Ball e colaboradores (2010) acompanharam 1625 indivíduos desde a gestação até o início da fase adulta e não encontraram associação entre 0 uso de cigarros durante a gravidez e o desenvolvimento de TDAH. Além disso, não houve diferenças na idade de início, número de sintomas ou probabilidade de remissão nos indivíduos com TDAH de mães que fumaram na gestação ou não.

As associações de TDAH com complicações pré e peri natais como prematuridade e baixo peso ao nascer, deficiência de ácidos graxos, zinco, ferro e a presença de aditivos alimentares estão sendo cada vez mais pesquisadas; entretanto, os resultados ainda não podem ser considerados conclusivos para todas essas possibilidades (St Sauver et al, 2004). 


\subsection{Neurobiologia}

Estudos morfométricos e de neuroimagem têm sido realizados a fim de identificar as regiões encefálicas com anormalidades em indivíduos com TDAH. As principais alterações encontradas em crianças e adolescentes foram reduções dos volumes: cerebral total, do córtex pré-frontal, do núcleo caudado, do globo pálido, do cíngulo anterior e do cerebelo, principalmente no vérmis e lóbulo inferior posterior (Berquin et al, 1998; Castellanos et al, 2002; Seidman et al, 2006; Louzã-Neto, 2010).

Valera e colaboradores (2007) realizaram uma meta-análise dos achados de imagem estrutural de crianças com TDAH e concluíram que as regiões mais frequentemente investigadas e que mostram as maiores diferenças incluem a regiões cerebelares, o esplênio do corpo caloso, o volume cerebral total e direito e o núcleo caudado direito.

Os déficits neuropsicológicos estão presumivelmente ligados a anormalidades estruturais e funcionais de regiões encefálicas. Dessa forma, o mapeamento das funções de atenção em diferentes regiões do cérebro pode ajudar a elucidar a neurofisiologia por trás do TDAH, a fim de se determinar como se relacionam com os diferentes fenótipos as alterações específicas na estrutura e na função cerebral (Kieling et al, 2008).

O desenvolvimento cerebral é caracterizado por uma série de etapas críticas, e cada uma delas deve ser corretamente cumprida para que, no final, o cérebro configure sua estrutura normal. No período de alta plasticidade, o cérebro se torna mais susceptível a estímulos. Assim, 
eventos que ocorrem durante as fases iniciais do desenvolvimento podem resultar em mudanças positivas ou negativas para o cérebro ao longo da vida (Andersen, 2003; Trojan et al, 2004).

Os períodos críticos durante o desenvolvimento são cruciais para a evolução normal, pois constituem as ocasiões em que as projeções neuronais competem por locais sinápticos, ou seja, quando o sistema nervoso otimiza as conexões neurais. Um dano ao sistema nervoso em desenvolvimento pode causar déficits que não são reconhecidos até idades mais tardias, quando a estrutura prejudicada se tornaria funcional (LundyEkman, 2008).

Castellanos et al (2002) acompanharam ao longo do tempo crianças e adolescentes com TDAH utilizando imagens de ressonância magnética, nos quais as anormalidades volumétricas no cérebro e cerebelo persistem com o aumento da idade. O transtorno associa-se a uma redução de cerca de 3\% no volume cerebral total e este decréscimo foi mais expressivo no cerebelo, não havendo relação com o uso ou não de medicação. Com exceção do núcleo caudado, as curvas longitudinais de crescimento das estruturas cerebrais se mantiveram praticamente paralelas às das crianças sem 0 transtorno, porém com valores menores, o que sugere que os sintomas neuropsiquiátricos parecem refletir insultos ou anormalidades neurobiológicas fixas e precoces.

Cada fase do desenvolvimento e do crescimento cerebral tem seu tempo e não ocorre individualmente. Tal maturação decorre de eventos aditivos/ progressivos (proliferação e migração neuronal, organização e 
mielinização) e substrativos/ regressivos (morte neuronal/apoptose, retração axonal e degeneração sináptica). O desenvolvimento de uma determinada função irá depender do amadurecimento de seu substrato neural anatômico correspondente (Zomignani, Zambell e Antonio, 2009).

Pesquisas recentes têm verificado um atraso na maturação cerebral (Shaw et al, 2007; Dopheide e Pliska, 2009; McLaughlin et al, 2010). Shaw et al (2007) compararam 223 crianças e adolescentes com TDAH, com 223 controles em estudos de neuroimagem para determinar a espessura cortical. Os resultados mostraram que em ambos os grupos o amadurecimento progride de forma similar. No entanto, nas crianças com TDAH houve um atraso na obtenção do pico de espessura cortical na metade dos pontos corticais estudados. $\mathrm{O}$ atraso foi mais proeminente nas regiões pré-frontais, sobretudo no córtex pré-frontal lateral. Nessas regiões encontram-se a maior parte das anormalidades estruturais e da hipoativação detectadas no TDAH, que estão ligadas às funções cognitivas, tais como: habilidade para inibir pensamentos e respostas indesejadas, controle executivo da atenção, avaliação das recompensas da ação, controle motor preciso e adequado àquela ação e memória operacional.

Outros estudos relacionam as regiões do cérebro afetadas no TDAH aos seus sintomas: o acometimento do córtex pré-frontal e parietal, do cerebelo, dos gânglios da base e dos circuitos associados determina alterações do controle inibitório, memória operacional, tempo de reação, além de outras FEs (Bush,Valera e Seidman, 2005; Valera et al, 2006; Seidman et al, 2006; Makris et al, 2007; Shaw et al, 2007). 
As FEs incluem a decisão de um objetivo, como chegar a esse objetivo, a execução de um plano e o monitoramento do resultado de uma ação (Lundy-Ekman, 2008). Esse conjunto de mecanismos, pelos quais o desempenho é otimizado nas situações que necessitam de processos cognitivos diferentes e simultâneos, envolve a habilidade de planejamento estratégico e busca organizada, com flexibilidade de pensamento e ação. Além de habilidades de selecionar o essencial de uma situação, resistir à distração e interferência, inibir respostas inadequadas, atender a múltiplas fontes de informação simultaneamente e sustentar comportamentos por períodos prolongados (Sergeant, Guerts e Oosterlaan, 2002; Willcut et al, 2005).

Os substratos neurais das FEs correspondem aos circuitos frontais, que compreendem a região frontal (pré-frontal) e suas conexões com o córtex posterior e com as áreas subcorticais (Klimkeit et al, 2005; Arnsten, 2005).

Uma metanálise de 16 estudos de neuroimagem, que compararam indivíduos com e sem TDAH, mostrou que durante tarefas que avaliam inibição de respostas, houve uma maior ativação do córtex pré-frontal, do cíngulo anterior, lobo parietal esquerdo e caudado direito nos controles do que naqueles com o transtorno (Dickstein et al, 2006; Dopheide e Pliszka, 2009).

Seidman et al (2006) observaram uma diminuição de cerca de 14\% no volume do cíngulo anterior de adultos com TDAH, quando comparados aos controles. Esta estrutura está localizada na região medial frontal e relaciona- 
se com o córtex pré-frontal dorsolateral, córtex parietal e estriado, o que a vincula aos processos cognitivos complexos como seleção e inibição de respostas, detecção de erro e motivação (Bush et al, 1999, Louzã Neto, 2010)

Além dessas regiões encefálicas já reconhecidas como determinantes no controle das FEs, a atuação cerebelar também tem sido investigada. $O$ cerebelo é uma região encefálica tradicionalmente associada ao controle motor, coordenação física e equilíbrio, porém estudos recentes sugerem que distintas regiões cerebelares também têm papel importante na cognição e no aprendizado (Bugalho, Correa e Viana-Baptista, 2006).

Sua função é coordenar o movimento e o controle postural ao comparar a estimulação motora efetiva ao movimento pretendido e ajustar o movimento quando necessário (Lundy-Ekman, 2008). O cerebelo influencia os sistemas motores através da avaliação de disparidades entre a intenção e a ação por meio do ajuste da atividade dos centros motores no córtex e no tronco encefálico, enquanto o movimento está acontecendo, bem como durante sua repetição. A experiência dos movimentos é capaz de promover alterações nos circuitos cerebelares, formando a base do aprendizado (Kandel, Schwartz e Jessel, 2003).

As conexões entre regiões específicas do cerebelo e áreas associativas dos hemisférios cerebrais verificadas em estudos anatômicos e funcionais, mostrando sua ativação em tarefas não motoras, permitem pensar que o cerebelo atua no controle de funções cognitivas específicas, tais como visuo-espaciais e comportamento. Foram encontradas ligações 
com diversas regiões do córtex pré-frontal, responsáveis pelas FEs, memória verbal e linguagem (Bugalho, Correa e Viana-Baptista, 2006).

Pesquisas têm mostrado um volume cerebelar menor nos pacientes com TDAH quando comparados a indivíduos sem o transtorno (Berquin et al, 1998; Giedd et al, 2001), outras demonstraram redução da atividade do cerebelo e do vérmis (Mackie et al, 2007). Essa redução do volume cerebelar pode ainda estar relacionada ao comprometimento das habilidades psicomotoras no TDAH, especialmente a coordenação motora global ou fina (Berquin et al, 1998; Castellanos et al, 2002; Seidman et al, 2006).

A prática clínica mostra que o TDAH e as dificuldades motoras têm uma relação muito estreita, cujo vínculo parece ser neuroevolutivo (Vidarte, Ezquerro e Giráldez, 2009). A criança hiperativa tem resposta aos variados estímulos ambientais com uma prontidão imediata. Parece não ser capaz de selecionar conscientemente a tarefa ou o objeto prioritário de sua ação e de não ter controle do próprio corpo, indicando uma desarmonia entre o sentir, o pensar e o agir (Antony e Ribeiro, 2004).

\subsection{Alterações motoras}

A habilidade psicomotora da criança com TDAH é significativamente mais baixa do que se espera. Por mais de um século, crianças com problemas motores têm sido associadas às dificuldades comportamentais de desatenção, hiperatividade e impulsividade. Houve uma aceitação geral de 
que aproximadamente até metade das crianças com TDAH possa ter dificuldades motoras (Pitcher, Piek e Hay, 2003).

Estudos clínicos e epidemiológicos referem que entre $30 \%$ e 50\% das crianças com TDAH sofrem de problemas na coordenação motora, essas porcentagens dependem do tipo de avaliação motora, referências e pontos de corte utilizados (Kadesjo e Gillberg, 2001; Visser, 2003; Polatajko e Cantin, 2005; Magalhaes, Missiuna e Wong, 2006; Fliers et al, 2009).

Pietcher, Pick e Hay (2003) avaliaram as habilidades motoras globais e finas de crianças com TDAH utilizando os testes Movement Assessment Battery for Children e Purdue Pegboard test. Os achados demonstraram que meninos com TDAH têm habilidade de movimento de qualidade inferior àqueles sem o transtorno.

As crianças com TDAH, quando comparadas com controles, foram reconhecidas como tendo maior quantidade e diferente qualidade de movimento. As flutuações na atividade motora sugeriram que houvesse falha na sua regulação para atender às demandas específicas de cada situação (Pereira, Araújo e Mattos, 2005).

Tseng et al (2004) investigaram a relação entre o desempenho motor, déficit de atenção, impulsividade e hiperatividade em 42 crianças com TDAH pareadas com 42 controles. Foram averiguadas relações entre atenção e controle de impulsos como preditores importantes de habilidades motoras finais e globais em crianças com TDAH. Contudo, o fato de o nível de atividade ser um preditor de proficiência motora grossa e não de testes motores finos sugere que diferentes processos comportamentais estão 
envolvidos na performance motora global e fina em diferentes graus.

Kroes et al (2002) realizaram um estudo prospectivo com o intuito de examinar se os aspectos quantitativos e/ou qualitativos do desempenho motor de crianças de cinco e seis anos de idade podem predizer o TDAH. O Maastricht Motor Test foi aplicado em 401 crianças, 18 meses depois 35 delas foram diagnosticadas com TDAH e o comprometimento dos domínios de equilíbrio dinâmico, diadococinesia, destreza manual e o escore quantitativo total mostraram relações significativas com o desenvolvimento do TDAH.

Rommelse et al (2007) avaliaram 350 crianças com TDAH, 195 irmãos não afetados e 271 crianças com idades entre cinco e 19 anos através de dois testes de controle motor computadorizados. As crianças com TDAH foram menos precisas e estáveis que as do grupo controle.

Pitcher, Pick e Hay (2003) identificaram dificuldades nas habilidades motoras finas em crianças com TDAH. Miyahara, Piek e Barrett (2006) realizaram exames neurológicos em meninos hiperativos que revelaram imaturidade no desenvolvimento da coordenação. Quanto à aptidão motora, foram notados atrasos na aquisição de marcos do desenvolvimento, como a habilidade de pedalar e o início da linguagem falada (Raynor, 2001; Pereira, Araújo e Mattos, 2005).

As crianças com TDAH não apenas têm problemas na motricidade fina, como também no equilíbrio (Raberger e Wimmer, 2003; Stray et al, 2009). Os exames dos déficits sensório-motores nas crianças com TDAH tendem a mostrar comprometimento da acuidade cinestésica e das 
habilidades motoras finas, porém com resultados inconsistentes (Piek e Dyck, 2004).

As consequências do TDAH são multifacetadas e incluem limitações nas atividades de vida diária, mudanças acadêmicas, problemas com habilidades sociais e dificuldades motoras. A pobre performance na escrita é um exemplo de uma habilidade afetada pelo transtorno que é comumente observada por educadores e clínicos nessa população e que podem influenciar negativamente o desempenho acadêmico e a auto-estima (Racine et al, 2008).

A psicomotricidade aponta a ação recíproca entre movimento, emoção, indivíduo e meio ambiente. Refere o movimento humano como instrumento essencial à construção do psiquismo e sustenta que a atividade motora constrói a imagem corporal, resultando da ação dinâmica de suas experiências. Essa imagem corporal leva a criança a agir no mundo de forma organizada e adaptada ao espaço envolvente. Portanto, o sujeito fala através do seu corpo e este é o desafio que nos lança a criança hiperativa com o seu corpo em contínuo movimento (Antony e Ribeiro, 2004).

A agitação marcada pela troca contínua de atividades leva a problemas na organização acadêmica e dificuldade de estabelecer relações de amizade. Um excessivo nível de atividade com movimentos corporais desnecessários, impulsividade, antecipação de respostas e inabilidade para esperar um acontecimento provocam dificuldade de aprendizagem e perturbações motoras, que podem resultar em fracasso escolar (Poeta e Rosa Neto, 2004). 
Vidarte, Ezquerro e Giráldez (2009) caracterizaram o perfil psicomotor de 422 meninos diagnosticados clinicamente com TDAH e compararam com 424 controles, por meio da bateria de observação psicomotora (BPM), sendo que os indivíduos do grupo caso demonstraram uma pontuação menor que o grupo controle (15,88 pontos contra 18,43), mas que como um todo correspondem a um desempenho "normal", uma execução "controlada" e um perfil "eupráxico". Mesmo com equivalência a valores normais, os meninos com TDAH alcançaram níveis de execução significativamente menores do que as crianças sem o transtorno em quase todos os fatores: tonicidade, equilíbrio, noção de corpo, estruturação espaço-temporal, praxia global e fina.

Poeta e Rosa Neto (2007) também avaliaram o perfil psicomotor, através da Escala de Desenvolvimento Motor (EDM), de 31 crianças com indicadores de TDAH baseados nos critérios da DSM-IV TR e da escala para avaliação do TDAH (EDAH) respondidos por pais e professores. Seus resultados foram similares aos desse estudo com a média do quociente motor correspondente a um desenvolvimento normal baixo. Os quocientes de todas as áreas avaliadas também apresentaram déficits, mas os maiores prejuízos observaram-se na organização temporal, organização espacial e equilíbrio.

Outros estudos nacionais sugerem que as crianças com TDAH têm dificuldades nas habilidades psicomotoras (Mello, Poeta e Rosa Neto, 2003; Silveira et al, 2006; Suzuki, Gugelmim e Soares, 2005; Di Nucci, 2007; Toniolo et al, 2009) e alguns relatos de caso descreveram a intervenção 
psicomotora nessas crianças (Valeski, Coelho e Rodrigues, 2004; Rosa Neto e Poeta, 2007). Porém, além de essas amostras ainda serem muito pequenas, algumas delas foram constituídas por crianças sem diagnóstico clínico confirmado pelo médico, outras sem a identificação dos subtipos e/ou a presença de comorbidades, fatores que poderiam influir em sua performance motora.

Estudos sobre intervenção motora são igualmente escassos na literatura internacional. Fliers et al (2009) confirmaram a hipótese de que os problemas motores no TDAH são uma área de atenção clínica negligenciada e que apenas metade dessas crianças recebem tratamento fisioterápico. Possivelmente, esses achados se devem a atuação do fisioterapeuta constituir uma intervenção nova no TDAH. Além disso, as comorbidades, como a ansiedade e o TC, tendem a direcionar as terapias à contenção desses sintomas, restringindo-se a abordagens comportamentais. Embora a fisioterapia seja eficiente na melhora da função motora de crianças com alterações da coordenação, os dados sobre o impacto desta intervenção em crianças com TDAH são insuficientes (Watemberg et al, 2007).

\subsection{Tratamento}

O tratamento do TDAH inclui orientação da família e da escola um suporte com terapia especializada e uso de medicamentos (APA, 2001). Rode e Halpern (2004) sugerem uma abordagem múltipla, englobando 
intervenções psicossociais e psicofarmacológicas de acordo com as necessidades de cada paciente.

O tratamento medicamentoso é importante e utilizado na maioria dos casos, pois determina acentuada redução dos sintomas cardinais e melhora significativamente as dificuldades sociais, familiares e escolares ou laborativas dos pacientes (Spencer, Biederman e Wilens, 2000).

Os efeitos benéficos da medicação incluem melhora da concentração, diminuição da impulsividade, de comportamentos agressivos e/ou antissociais, da hiperexcitabilidade e diminuição da agitação motora (Louzã Neto, 2010), além de melhora na motivação, coordenação motora, habilidade visomotora e da interação pessoal (Steer, 2005; The MTA Cooperative Group, 1999).

As medicações estimulantes como metilfenidato, um derivado anfetamínico, são os agentes farmacológicos mais utilizados no TDAH e podem propiciar alívio sintomático significativo, com melhora do comportamento e do rendimento escolar (Spencer, Biederman e Wilens, 2000; Swanson et al 2003).

Os benefícios do uso do metilfenidato aparecem em $70 \%-80 \%$ dos artigos científicos. Todas as publicações científicas analisadas, que abordam o TDAH, confirmam, em seus resultados, a eficácia do uso do medicamento como terapêutica para o transtorno e concluem que o medicamento é imprescindível no tratamento do transtorno (Ortega et al, 2010).

Outros medicamentos também são utilizados para o tratamento do TDAH embora não tenham a mesma eficácia do metilfenidato. Os 
medicamentos mais frequentemente utilizados no TDAH são os estimulantes, os antidepressivos (tricíclicos e bupropiona), os agonistasadrenérgicos (clonidina/guanfacina), a atomoxetina e o modafinil (Demetrio e Teng, 2007).

O tratamento medicamentoso quando associado ao acompanhamento multidisciplinar converge para um melhor desempenho das crianças com TDAH (Araújo, 2002). A abordagem terapêutica deve ser multimodal, pois a criança com TDAH requer atenção especial em diversos contextos, como em casa, na escola e no convívio social (Desidério e Miyasaki, 2007).

Assim, as terapias de suporte são indicadas de forma individualizada. Algumas crianças precisam de acompanhamento fonoaudiológico, outras de pedagogos, mas a maioria das famílias necessitará em algum momento do suporte psicoterápico (Araújo, 2002). A integração dos serviços com um psiquiatra infantil, psicólogo e/ou profissionais da saúde mental pode ser indicada, especialmente se a criança com TDAH é afetada pela coexistência de comorbidades e continua a experimentar dificuldades, apesar do tratamento medicamentoso (Magyary e Brandt, 2002; Cormier, 2008).

A modalidade psicoterápica mais estudada e com maior evidência científica de eficácia para redução dos sintomas do TDAH, bem como para o manejo de sintomas comportamentais comumente associados é a terapia cognitivo-comportamental (Knapp et al, 2003). Dentre os tratamentos comportamentais, o treinamento parental parece ser a modalidade mais eficaz (Rohde e Halpern, 2004). 
Embora nem toda criança necessite psicoterapia, todo caso de TDAH requer orientação. Esta intervenção se faz necessária quando existe comorbidade e/ou problemas secundários considerados graves e de difícil solução na escola, em casa ou socialmente (Desidério e Miyasaki, 2007).

O estudo mais importante a respeito da terapêutica do TDAH foi o Multimodal Treatment Study (MTA Study), que analisou, por 14 meses de modo randomizado e cego, 579 pacientes com TDAH, de 7 a 9 anos, divididas em quatro grupos: tratamento apenas medicamentoso, apenas psicoterápico comportamental com as crianças e orientação para os pais e professores, abordagem combinada e tratamento comunitário demonstraram uma eficácia superior da medicação nos sintomas centrais do TDAH quando comparada à abordagem psicoterápica e ao tratamento comunitário. A abordagem combinada (medicação + abordagem psicoterápica comportamental com as crianças e orientação para os pais e professores) não resultou em eficácia maior nos sintomas centrais do transtorno quando comparada à abordagem apenas medicamentosa (The MTA Cooperative Group, 1999).

No entanto, pesquisas subsequentes, utilizando diferentes abordagens para análise dos dados, encontraram que os resultados da combinação dos tratamentos medicamentoso e psicossocial são superiores a qualquer dessas intervenções isoladas (Connors, Eptstein e Marsh, 2001; Swanson, Kraemer e Hinshaw, 2001). Além disso, a melhora nos sintomas cardinais do TDAH foi alcançada utilizando medicação em doses significativamente menores no grupo de tratamento combinado do que a 
administrada no grupo de tratamento exclusivamente medicamentoso (Cormier, 2008).

A associação da família, da escola, dos terapeutas e dos médicos é fundamental para que as medidas tomadas tenham melhor efeito (Araújo, 2002). Também a comunicação entre os pais, professores e demais profissionais da escola são essenciais para a monitoração do progresso e efetividade das intervenções (Cormier, 2008).

\subsection{Avaliação do desenvolvimento infantil}

O desenvolvimento humano pode ser entendido como o conjunto de variações que ocorrem no indivíduo por força de disposições interiores e pela influência de fatores ambientais (Santos e Cruz, 2001).

A definição de desenvolvimento infantil é uma tarefa complexa, pois varia de acordo com o referencial teórico adotado e com os aspectos que se quer abordar. Pode ser entendido como um processo contínuo, que se inicia na concepção, envolve vários aspectos, indo desde o crescimento físico, passando pela maturação neurológica, motora, comportamental, cognitiva, social e afetiva da criança. Tem como produto tornar a criança competente para responder as suas necessidades e às do seu meio, considerando seu contexto de vida (OPAS, 2005).

Os termos crescimento e desenvolvimento podem ser associados, porém cada um apresenta um enfoque diferenciado. O crescimento físico refere-se a um aumento da estrutura ou tamanho corporal, em função da 
multiplicação ou aumento de células, do indivíduo em maturação. O desenvolvimento é definido como sendo modificações no nível do funcionamento de um indivíduo ao longo do tempo e, portanto é um processo em que todas as mudanças adaptativas (interações entre indivíduo e ambiente) direcionam - se a adquirir ou manter a habilidade. Assim, a criança se caracteriza por uma variação da taxa de crescimento, pelo desenvolvimento das aptidões motrizes e do refinamento da discriminação perceptiva (Gallahue e Ozmun, 2003).

Sendo o desenvolvimento da criança decorrente de uma interação entre as características biológicas e as experiências oferecidas pelo meio ambiente, fatores adversos nestas duas áreas podem alterar o seu ritmo normal. A probabilidade de que isto ocorra é chamado de risco para o desenvolvimento (OPAS, 2005). Para entender as possíveis ameaças ao desenvolvimento típico e pleno deve-se considerar o enfoque de risco como uma forma de reconhecer e acompanhar precocemente alguns grupos mais vulneráveis (Maria-Mengel, 2007).

$\mathrm{Na}$ infância os momentos críticos no processo de evolução tornam-se mais facilmente detectáveis, por isso a avaliação do desenvolvimento nessa fase da vida é fundamental, uma vez que, pode monitorar alterações desenvolvimentistas, identificar atrasos, obter esclarecimento sobre estratégias instrutivas e intervencionistas e traçar o perfil psicomotor, proporcionando uma programação física adequada para a realidade de cada um (Rosa Neto et al, 2009). 
No Brasil, os programas de acompanhamento do crescimento e desenvolvimento têm se direcionado ao bebê de risco, nos quais a criança e a família são acompanhadas por equipes multi e interdisciplinares, com o objetivo de avaliar e acompanhar diversos aspectos da saúde infantil, desde condições físicas até alterações cognitivas e comportamentais (Vieira, Ribeiro e Formiga, 2009). No entanto, são escassos os estudos publicados que relatam o acompanhamento do desenvolvimento da criança após os dois anos de idade.

Por outro lado, as práticas em saúde pública já têm apontado a preocupação com o monitoramento do desenvolvimento infantil até a adolescência, verificados através de screenings, vigilância, avaliação e acompanhamento do desenvolvimento na atenção básica. Screenings de desenvolvimento são processos de checagem metodológica do desenvolvimento das crianças aparentemente normais, com o objetivo de se identificar crianças de alto risco para problemas de desenvolvimento, utilizando-se a aplicação de testes ou escalas, exames e outros procedimentos. A vigilância do desenvolvimento compreende todas as atividades relacionadas à promoção do desenvolvimento normal e à detecção de problemas de desenvolvimento, na atenção primária à saúde da criança, sendo um processo contínuo, flexível, envolvendo informações dos profissionais de saúde, pais, professores e outros. A avaliação do desenvolvimento constitui uma investigação mais detalhada de crianças com suspeita de serem portadoras de problemas no desenvolvimento, sendo geralmente multidisciplinar e diagnóstica. $\mathrm{O}$ acompanhamento do 
desenvolvimento é o procedimento de assistir de forma próxima o desenvolvimento da criança, sem implicar na aplicação de técnica ou processo específico, podendo ser periódico ou contínuo, sistemático ou informal e envolver ou não processo de screening, vigilância ou avaliação (OPAS, 2005).

Existem vários instrumentos padronizados que auxiliam na identificação dessas crianças de risco. Esses testes e escalas de desenvolvimento facilitam e auxiliam tanto a triagem e o diagnóstico quanto o planejamento e progressão do tratamento, caso alguma anormalidade seja detectada (Rosa Neto et al, 2005; Vieira, Ribeiro e Formiga, 2009). Apesar de existir um consenso entre os profissionais sobre a importância no acompanhamento do desenvolvimento da criança, a maneira como fazê-lo ainda é controvertida (OPAS, 2005).

Atualmente no Brasil, existe pouca literatura tanto de escalas, que são em sua maioria, produzidas em outros países, como há pequena produção e divulgação nacional de novos métodos de avaliação ou validação dos já existentes (Vieira, Ribeiro e Formiga, 2009).

Contudo, com o objetivo de avaliar o desenvolvimento psicomotor foi publicada e validada por Rosa Neto a EDM (Rosa Neto, 2002; Rosa Neto et al, 2010ab; Corazza et al, 2010; Amaro et al, 2009) que é utilizada principalmente em atividades vinculadas ao Laboratório de Desenvolvimento Humano da Universidade do Estado de Santa Catarina.

Este instrumento foi elaborado a partir de outros testes motores respaldados por autores clássicos como Ozerestski, Brunet e Lezina, Berges 
e Lezine, Mira-Stambak, Galifret-Granjon, Piaget e Head e utiliza uma bateria de testes envolvendo motricidade fina, motricidade global, equilíbrio, esquema corporal e organização espacial (Rosa Neto, 2002; Poeta e Rosa Neto, 2004; Silveira et al, 2006; Amaro et al, 2009; Rosa Neto et al, 2010ab; Corazza et al, 2010).

Essa escala aparece com o propósito de colocar à disposição dos profissionais da saúde e da educação um conjunto de instrumentos diagnósticos que Ihes permitem utilizar um método eficaz para realizar estudos transversais e longitudinais por provas construídas sobre princípios técnicos, científicos, com critérios práticos e coerentes (Suzuki, Gugelmin e Soares, 2005).

Os testes compreendem tarefas específicas para cada faixa etária (dois a 11 anos) em cada elemento da motricidade. A complexidade da tarefa a ser realizada aumenta de acordo com o aumento da idade (Rosa Neto, 2002).

A EDM determina as idades motoras (média aritmética dos resultados dos testes que se expressam em meses) e os quocientes motores (divisão entre a idade motora e a idade cronológica multiplicada por 100).

Os participantes são avaliados a partir do teste correspondente à sua idade cronológica em cada elemento da motricidade, e terminam a avaliação quando não desempenham corretamente a tarefa proposta. A idade correspondente à última tarefa desempenhada corretamente pela criança caracteriza-se por idade motora. Comparando-se a idade cronológica e a idade motora pode-se determinar o avanço ou atraso motor da criança. 
São considerados, como sugere a escala, os escores de sucesso (1) e fracasso (0) na tarefa, bem como o escore (1/2) que representa o sucesso com apenas um dos membros em determinadas tarefas.

Assim, os resultados dos quocientes motores, que correspondem às divisões entre as idades motoras e a idade cronológica multiplicada por 100 , permitem estabelecer a seguinte classificação:

\begin{tabular}{cl} 
Tabela 1 - Classificação dos resultados da \\
\cline { 2 - 2 } Pontuação & Desenvolvimento \\
\hline 130 ou mais & Muito superior \\
$120-129$ & Superior \\
$110-119$ & Normal alto \\
$90-109$ & Normal médio \\
$80-89$ & Normal baixo \\
$70-79$ & Inferior \\
69 ou menos & Muito inferior \\
\hline
\end{tabular}

A EDM foi escolhida para esse estudo por ser de fácil aplicação, apresentar um método de aplicação de testes atrativo para a criança e abranger os diversos aspectos relacionados ao desenvolvimento psicomotor. Além disso, não é necessária a autorização formal para o uso da escala, sua utilização é livre para profissionais interessados em avaliar o desenvolvimento e desempenho psicomotor de crianças. 


\subsection{Habilidades psicomotoras}

O movimento é comandado pela ação conjunta e coordenada das regiões periférica, medular, tronco encefálico / cerebelar e cerebral, que é adequada por um contexto específico e guiada pelas intenções do indivíduo. Dessa forma, os atos motores básicos desenvolvem-se a partir das interações entre maturação nervosa, crescimento e meio ambiente, que levam ao aparecimento das habilidades motoras em consequência da melhora da organização e da eficácia para realização de qualquer atividade (Lundy-Ekman, 2008).

Não existe movimento sem cognição (Di Nucci, 2007), por isso há uma estreita relação entre o que a criança é capaz de realizar (motor) e o que é capaz de aprender (cognitivo). Assim, o desenvolvimento motor está vinculado ao desenvolvimento da percepção corporal, espacial e temporal, ou seja, adquirir um bom controle motor implica em construir noções fundamentais ao desenvolvimento intelectual (Rosa Neto et al, 2010a).

Entre os elementos básicos da motricidade humana encontramos a motricidade fina, a motricidade global, o equilíbrio, o esquema corporal, a organização espacial e a organização temporal, que são elaborados de modo progressivo com a evolução motriz e aprendizado da criança (Rosa Neto, 2002).

A motricidade fina corresponde à coordenação visuo-manual, também chamada de praxia fina, inclui a fase de transporte da mão, seguida da fase de agarre e manipulação, resultando em um conjunto com três 
componentes: objeto, olho e mão (Rosa Neto, 2002; Rosa Neto et al, 2010a). As habilidades visuo-motoras associadas à cinestesia, ao planejamento motor, à destreza manual e a atenção sustentada estão intimamente ligadas à habilidade de escrita (Racine et al, 2008). As habilidades motoras finas são essenciais para muitas ocupações diárias, tais como vestir-se e escrever (Tseng et al, 2004).

A motricidade global relaciona-se à capacidade da criança, seus gestos, suas atitudes, seus deslocamentos e seus ritmos (Rosa Neto, 2002; Di Nucci, 2007). O movimento motor global, mesmo sendo o mais simples, é uma ação sinestésica, tátil, visual, espacial, temporal e labiríntica. A coordenação motora global está intrinsecamente ligada ao equilíbrio (Rosa Neto, 2002; Amaro et al, 2009).

O equilíbrio é a capacidade de manter o centro de massa em relação à base de apoio (Suzuki, Gugelmim e Soares, 2005; Lundy-Ekman, 2008). Constitui o alicerce primordial de toda ação diferenciada dos segmentos corporais, possibilita a manutenção de posturas, posições e atitudes e é derivado de um conjunto de informações proprioceptivas (Rosa Neto, 2002). Pode ser definido como a manutenção de uma postura particular do corpo com um mínimo de oscilação (equilíbrio estático) ou a manutenção da postura durante o desempenho de uma habilidade motora que tenda a perturbar a orientação do corpo (equilíbrio dinâmico) (Silveira et al, 2006).

O movimento humano é um instrumento essencial à construção do psiquismo. A atividade motora constrói a imagem e o esquema corporal, resultados da ação dinâmica das experiências do indivíduo, que levam a 
criança a agir no mundo de forma organizada e adaptada ao espaço envolvente (Antony e Ribeiro, 2004).

A construção do esquema corporal tem papel fundamental no desenvolvimento da criança, já que corresponde à organização das sensações relativas a seu próprio corpo em relação ao mundo exterior, que é o ponto de partida de diversas possibilidades de ação (Rosa Neto, 2002). Para guiar o movimento pelo espaço, o cérebro deve monitorar constantemente a posição e o movimento do corpo em relação aos objetos próximos. O controle efetivo do corpo requer uma representação neural integrada do corpo e o espaço ao redor do corpo (Holmes e Spence, 2004).

A percepção relativa à posição do corpo no espaço e ao movimento tem como origem diferentes receptores sensoriais (labirinto, receptores articulares e tendinosos, fusos neuromusculares e pele), enquanto a orientação espacial dos objetos ou dos elementos do meio necessita mais da visão e da audição. A integração dessas informações internas e externas forma a organização espacial (Rosa Neto, 2002).

A estruturação do corpo no espaço e no tempo constitui um elemento importante para a adaptação do indivíduo ao meio de forma integrada com a formação corporal. A noção de organização temporal é estabelecida pela compreensão da sucessão e peridiocidade das mudanças que ocorrem ao longo do tempo (Medina, Rosa e Marques, 2006). Percebemos o transcurso do tempo a partir das mudanças que se produzem durante um período estabelecido e da sua sucessão, que transforma progressivamente o futuro em presente e, depois, em passado (Rosa Neto, 2002). 
Ressalta-se a importância das habilidades motoras e dos aspectos referentes à sua aplicação nas tarefas escolares, visto que dificuldades em determinados campos do desenvolvimento podem gerar atrasos e influenciar no avanço em tarefas de outras áreas relacionadas à aprendizagem em geral (Medina-Papst e Marques, 2010).

Por isso, o reconhecimento precoce de situações que necessitem de suporte favorece o início dos mesmos, antes que complicações emocionais secundárias se instalem. A partir da identificação, a correção adequada dos problemas permite ao indivíduo o percurso da vida escolar em iguais condições que os demais (Araújo, 2002).

Problemas motores geralmente não fazem parte dos processos diagnósticos e terapêuticos no TDAH (Gilllberg e Kadesjo, 2003; Gillberg et al, 2004; Sergeant, Piek e Oosterlaan, 2006; Fliers et al, 2009). Alterações motoras causam dificuldades em, por exemplo, andar de bicicleta, vestir-se, amarrar os sapatos, escrita e práticas de esportes, e assim podem reduzir a participação social e gerar desvantagem (Fliers et al, 2009).

Daí a importância de estudos que verifiquem os aspectos relacionados ao desenvolvimento psicomotor das crianças com TDAH, a fim de analisar as possíveis falhas e possivelmente sugerir a intervenção adequada. 


\section{OBJETIVOS}

\subsection{Objetivo Geral}

- Traçar o perfil psicomotor de crianças com TDAH tipo combinado.

\subsection{Objetivos Específicos}

- Avaliar o desenvolvimento e as habilidades psicomotoras de crianças com TDAH tipo combinado.

- Identificar as possíveis alterações psicomotoras.

- Comparar o perfil psicomotor entre os grupos com TDAH e controle. 


\section{MÉTODOS}

A referida pesquisa foi constituída de um estudo transversal, sendo desenvolvida segundo abordagens quantitativa e qualitativa. Este trabalho foi previamente aprovado pelo Comitê de Ética em Pesquisa da Faculdade de Medicina da Universidade de São Paulo, sob o número CAPPesq 0573/08 (Anexo 1).

\subsection{Local da pesquisa}

O grupo caso foi avaliado no Ambulatório de TDAH do Serviço de Neurologia Infantil do Instituto Central e no Ambulatório de Distúrbios do Aprendizado do Instituto da Criança do Hospital das Clínicas da Faculdade de Medicina da Universidade de São Paulo (HCFMUSP). As avaliações das crianças do grupo controle foram realizadas na Escola Estadual Keizo Ishirara e na Escola Estadual Eduardo Carlos Pereira (Anexos 2 e 3).

\subsection{Casuística}

\subsubsection{Cálculo da Amostra}

A amostra foi calculada a partir de dados de um estudo piloto realizado previamente. Os parâmetros utilizados para o cálculo foram: alfa (erro do tipo I) bi-caudal de $5 \%$, beta ou poder (erro do tipo II) de $20 \%$ e os 
resultados da média e desvio padrão da idade de cada grupo caso e controle. A partir destes parâmetros, estimou-se uma amostra de 33 crianças em cada grupo, entretanto optou-se incluir mais $20 \%$ para possíveis perdas e recusas.

\subsubsection{Sujeitos}

Para formar o grupo caso, foram avaliados 34 meninos acompanhados nos ambulatórios referidos, com diagnóstico de TDAH do tipo combinado, sem comorbidades (exceto o TDO) e sem ter iniciado tratamentos, durante o período de março de 2009 a março de 2010.

Os critérios de inclusão para a seleção dos sujeitos do grupo caso foram: estar em acompanhamento médico - ambulatorial, ter idade entre sete e onze anos (idade mínima determinada pela faixa etária comum do diagnóstico e idade máxima condicionada pela escala), ser do sexo masculino, apresentar diagnóstico médico de TDAH tipo combinado baseado no roteiro de entrevista proposto pelo DSM-IV TR, não apresentar comorbidades, exceto o TDO (por ser a comorbidade mais comum), não ter iniciado tratamento clínico ou medicamentoso até a data da avaliação, colaboração no processo de avaliação, aceitação dos pais e/ou responsáveis da participação no estudo e assinatura do Termo de Consentimento Livre e Esclarecido (TCLE) (Anexo 4).

grupo controle foi formado por 32 meninos da rede pública de ensino do município de São Paulo, e seguiu os mesmos critérios de inclusão 
em relação ao sexo, idade, colaboração, aceitação e assinatura do TCLE (Anexo 5). Os critérios de exclusão deste grupo foram: fazer uso regular de medicamento e apresentar problemas físicos e/ou mentais.

Os critérios de exclusão deste trabalho, em ambos os grupos, foram: apresentar distúrbios visuais, auditivos, cardiopatias, disfunções reumatológicas ou ortopédicas, exame neurológico alterado, deficiência mental e distúrbios comportamentais graves.

\subsection{Procedimentos}

As crianças com TDAH foram inicialmente selecionadas a partir de uma triagem através da utilização do questionário SNAP-IV (Anexo 6), preenchido pelos respectivos pais e professores. Neste estudo foi utilizada a versão reduzida, com 18 itens, excluindo-se os itens de investigação de TDO, uma vez que a presença desta comorbidade no grupo caso não constituiu um fator de exclusão.

A seguir, as crianças suspeitas foram atendidas nos ambulatórios de acordo com as normas habituais para este tipo de transtorno, sendo preenchido um protocolo (Anexo 7), após a consulta inicial, pelo médico neurologista, com os critérios diagnósticos de acordo com o DSM-IV TR.

A partir da confirmação do diagnóstico, do subtipo e da ausência de comorbidades, exceto o TDO, os pacientes foram avaliados pela própria pesquisadora segundo os testes propostos por este estudo, em salas nos ambulatórios. 
A escolha das crianças do grupo controle foi feita aleatoriamente pelas professoras das escolas, que foram orientadas a não escolher aquelas com sinais e/ou sintomas relacionados ao TDAH ou ainda com base em seu desempenho físico ou acadêmico, ou seja, não selecionar nem os melhores nem os piores alunos, mas sim os medianos, para que a amostra pudesse representar de forma mais significativa a população em geral.

Para garantir que as crianças indicadas pelas professoras não apresentassem sintomas expressivos de desatenção, hiperatividade ou impulsividade, o SNAP IV (18 itens) foi preenchido pelos respectivos pais. Este questionário foi enviado juntamente com um manual explicativo sobre a pesquisa (Anexo 8) e o TCLE para o domicílio de 100 alunos. Apenas 43 questionários retornaram preenchidos, porém dois destes pais e/ou responsáveis não assinaram o TCLE. As seis crianças do sexo feminino deste grupo foram excluídas deste trabalho, conforme a modificação do desenho do estudo.

Após o retorno dos questionários e autorização formal dos pais e/ou responsáveis à participação na pesquisa, os escolares foram avaliados pela própria pesquisadora, retirados individualmente da sala de aula, em sala destinada para a realização dos testes na própria escola, em horário escolar.

Todas as crianças foram avaliadas por meio da EDM (Rosa Neto, 2002) (Anexo 9), sendo utilizados todos os testes da bateria motora proposta.

Todos os testes foram aplicados em uma única sessão, cujo tempo médio de avaliação foi de aproximadamente 40 minutos. 


\subsection{Análise Estatística}

Inicialmente, o teste de Shapiro-Wilks foi empregado para averiguar o enquadramento das vaiáveis numéricas no modelo de Gaussiano de distribuição. Diante dos resultados apresentados por este teste, constatou-se que nem todas as variáveis numéricas apresentam distribuição paramétrica. Assim, valores de média e intervalos de confiança de $95 \%$ (IC $\left.\mathrm{C}_{95 \%}\right)$ foram apresentados como estatística descritiva. Posteriormente, o teste $\mathrm{t}$ de Student para dados independentes e 0 teste $U$ de Mann-Whitnney estabeleceram comparações entre valores de média e mediana, respectivamente; observados para ambos os sexos. O pacote estatístico Stata versão 11.0 (Stata Corporation, College Station, TX, E.U.A.) foi utilizado para todos os cálculos estatísticos. 


\section{RESULTADOS}

A amostra foi composta por 66 crianças, do sexo masculino, sendo 34 sujeitos do grupo caso, diagnosticados clinicamente com TDAH do tipo combinado (Anexo 10) e 32 indivíduos do grupo controle (Anexo 11). A idade cronológica variou de sete a 11 anos (84 a 132 meses) em ambos os grupos, com média de cerca de nove anos (108,7 meses no grupo caso e 107,2 meses no grupo controle).

Os gráficos 1 e 2 demonstram a distribuição em porcentagem da classificação do desenvolvimento motor das crianças avaliadas segundo a EDM.

No grupo caso (gráfico 1), 18 (53\%) indivíduos apresentaram desenvolvimento normal médio, $10(29 \%)$ normal baixo, três (9\%) muito inferior, duas (6\%) normal alto e apenas uma (3\%) obteve desenvolvimento motor inferior. Dessa forma, $12 \%$ das crianças com TDAH do tipo combinado apresentaram desenvolvimento motor abaixo da normalidade. 
Gráfico 1 - Distribuição da classificação do desenvolvimento do grupo caso.

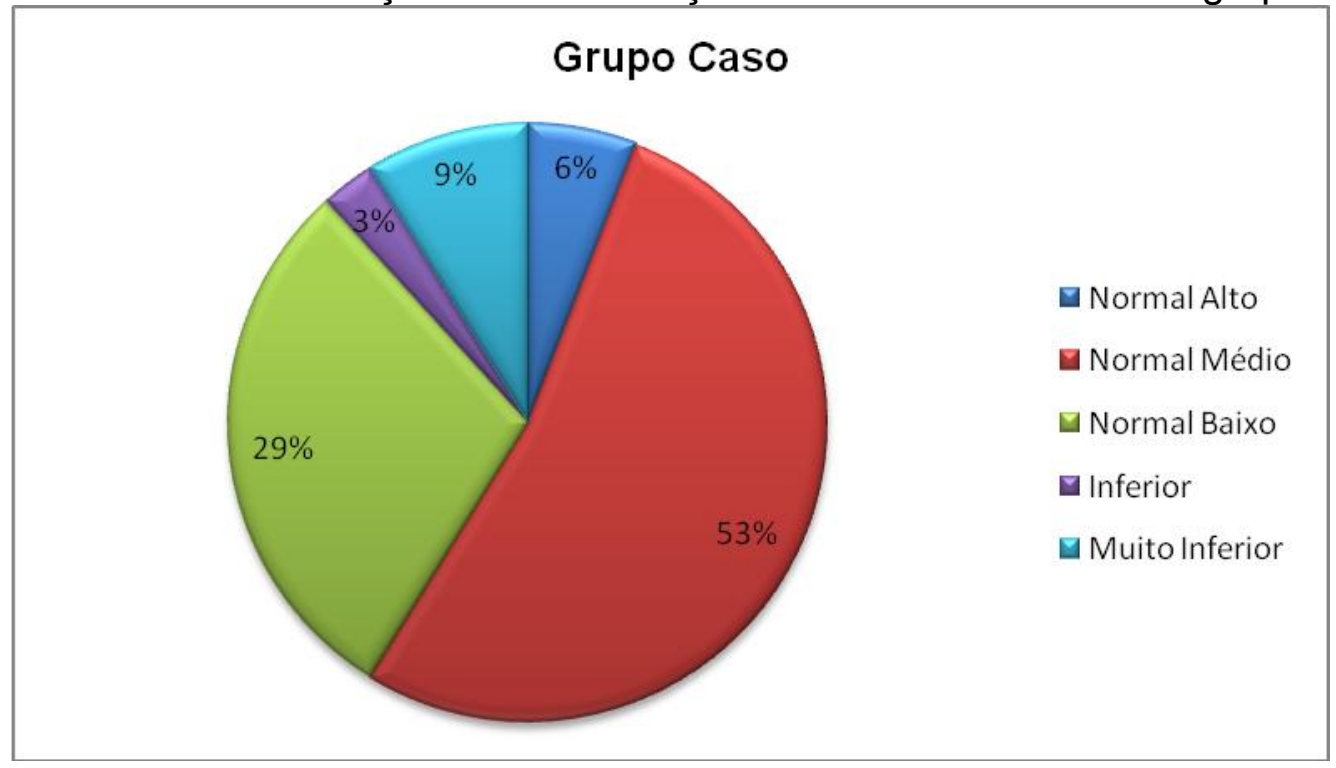

No grupo controle (gráfico 2), 25 (78\%) crianças alcançaram desenvolvimento normal médio, 4 (13\%) normal baixo e $3(9 \%)$ normal alto. Nenhum integrante deste grupo se classificou com desenvolvimento inferior ou muito inferior.

Gráfico 2 - Distribuição da classificação do desenvolvimento do grupo controle.

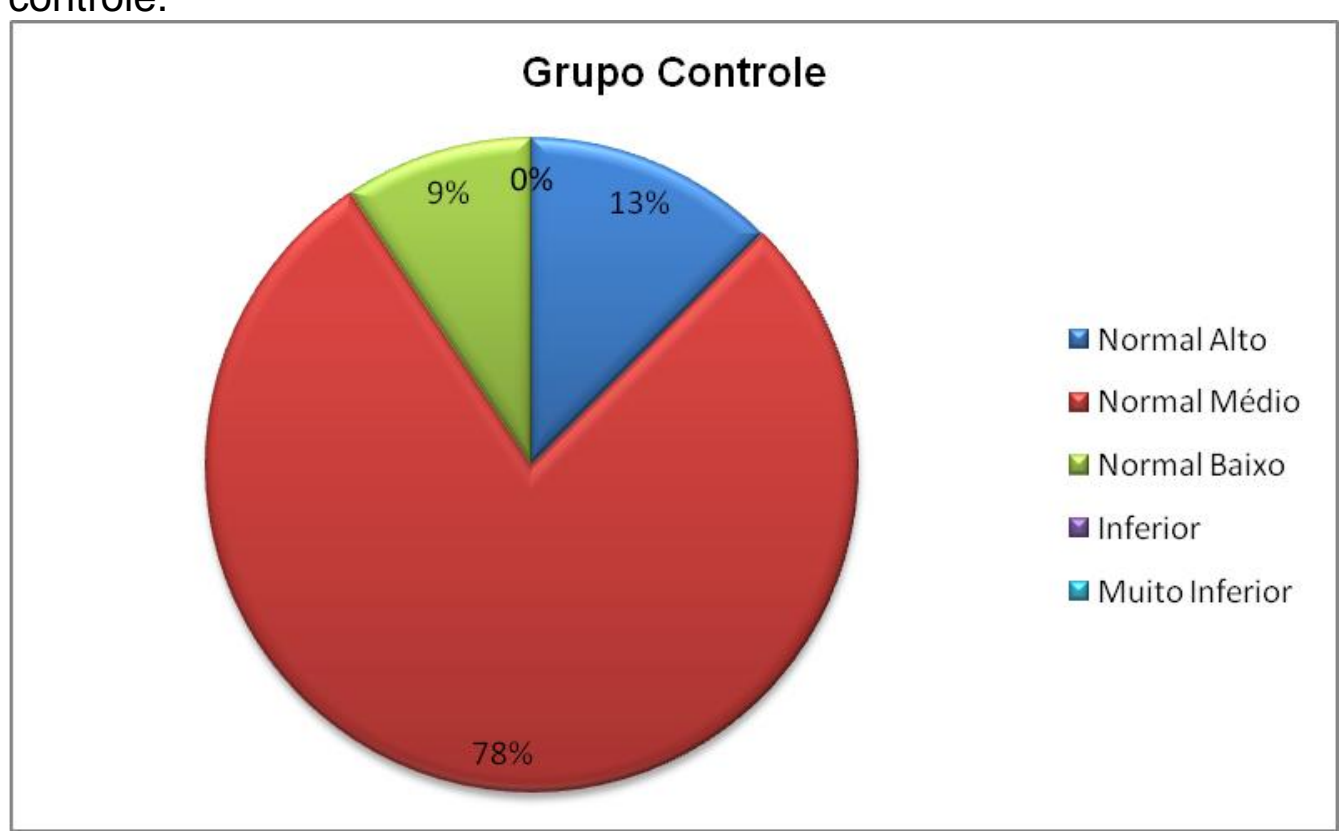


$\mathrm{Na}$ tabela 2 encontram-se as médias dos valores dos quocientes motores atingidos pelas crianças avaliadas e a classificação correspondente segundo a EDM. As médias dos quocientes motores de todas as áreas estudadas foram mais baixas no grupo caso que no grupo controle, exceto na organização temporal. A média da pontuação do quociente motor geral determinou a categorização do desenvolvimento motor das crianças com TDAH do tipo combinado como normal baixo.

A tabela 3 apresenta a distribuição das crianças avaliadas, em porcentagem, quanto à classificação dos quocientes motores segundo a EDM, em cada habilidade psicomotora. Nas classificações que refletem prejuízo (muito inferior e inferior) a porcentagem de crianças com TDAH foi maior do que os indivíduos sem o transtorno em todas as habilidades avaliadas, exceto na organização temporal. 


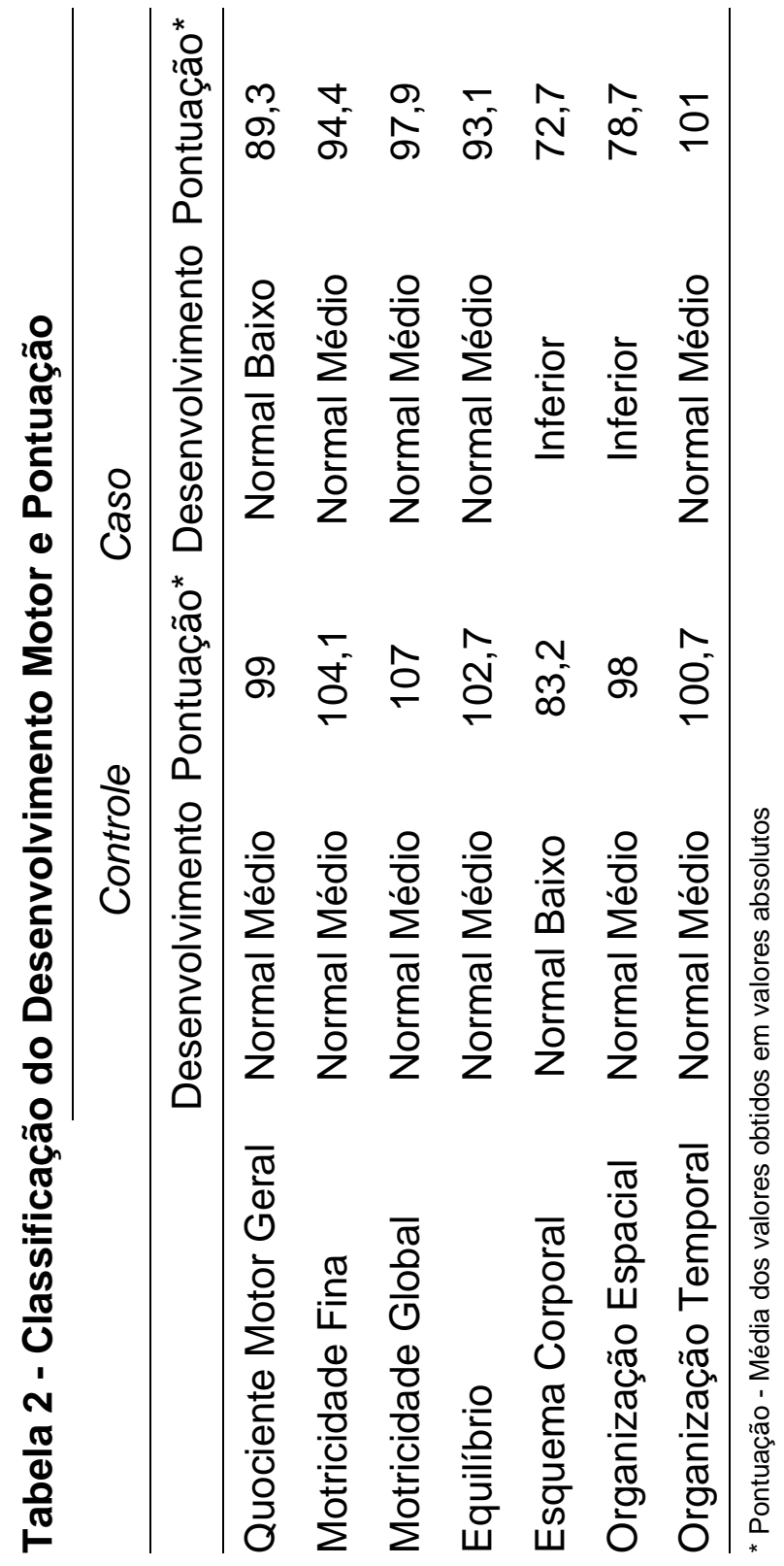




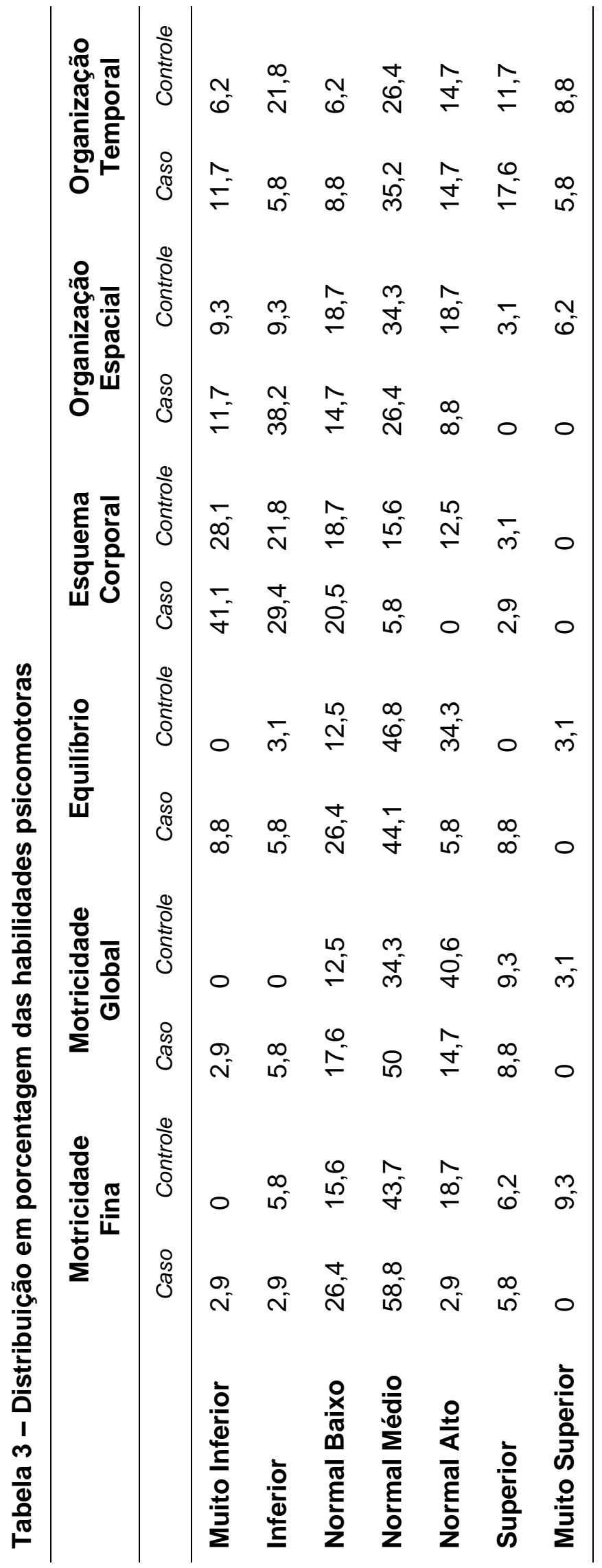


A tabela 4 descreve as médias dos resultados obtidos na EDM, os desvios-padrão, os intervalos de confiança e os valores de $p$. Houve diferença estatisticamente significativa entre os grupos quanto à idade motora geral, quociente motor geral, motricidade fina (quociente motor), motricidade global (quociente motor), equilíbrio (idade motora e quociente motor), esquema corporal (idade motora) e organização espacial (idade motora e quociente motor). Além disso, as médias dos valores obtidos na avaliação foram mais baixas nos indivíduos com TDAH tipo combinado do que as dos controles em todas as habilidades psicomotoras estudadas, exceto na organização temporal. 


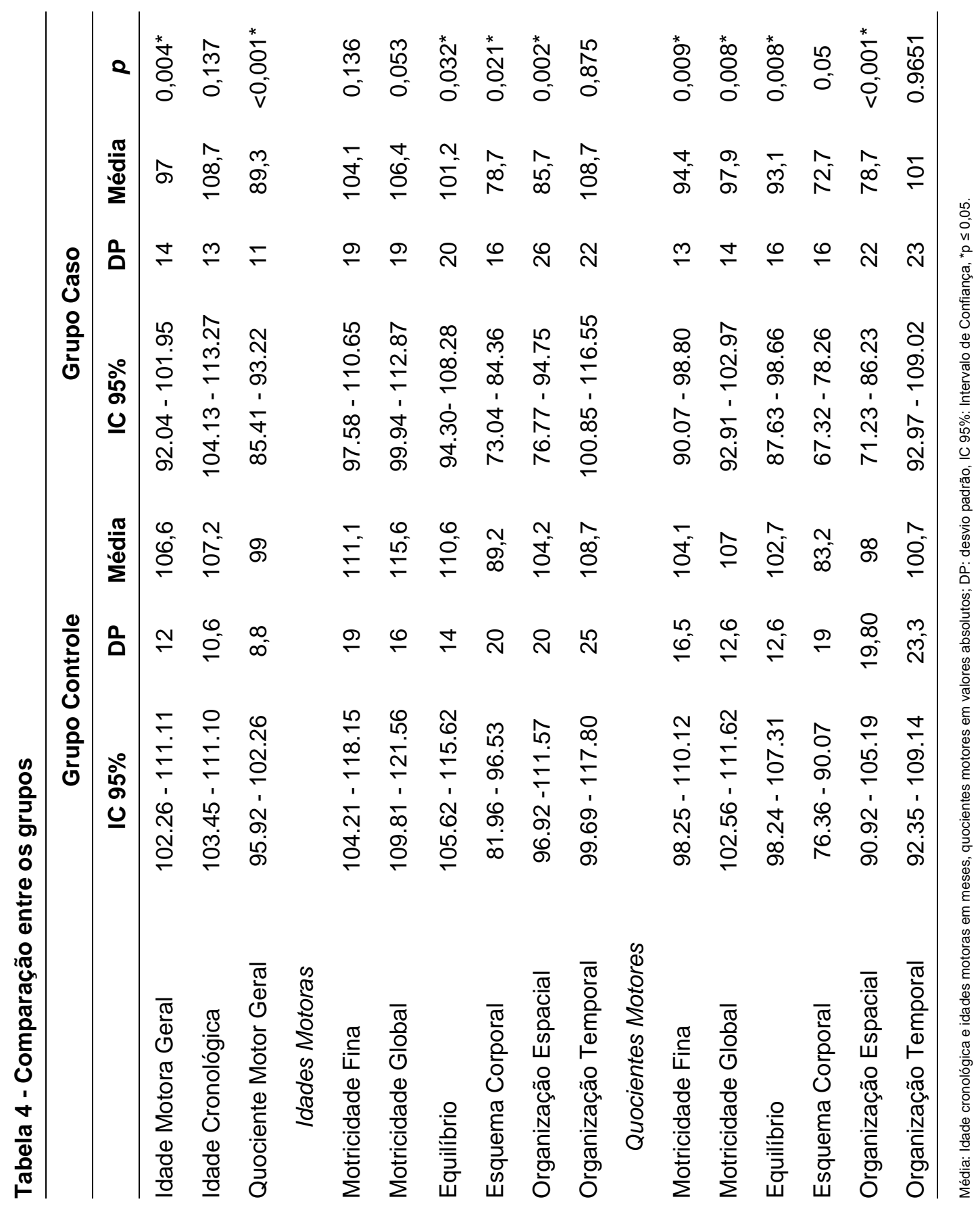


O gráfico 3 apresenta os valores da diferença entre a idade motora geral e a idade cronológica de cada indivíduo. Esse resultado determina o atraso (idade negativa) ou o avanço (idade positiva) do desenvolvimento motor, segundo a EDM.

Gráfico 3 - Diferença entre a idade motora geral e a idade cronológica de cada indivíduo

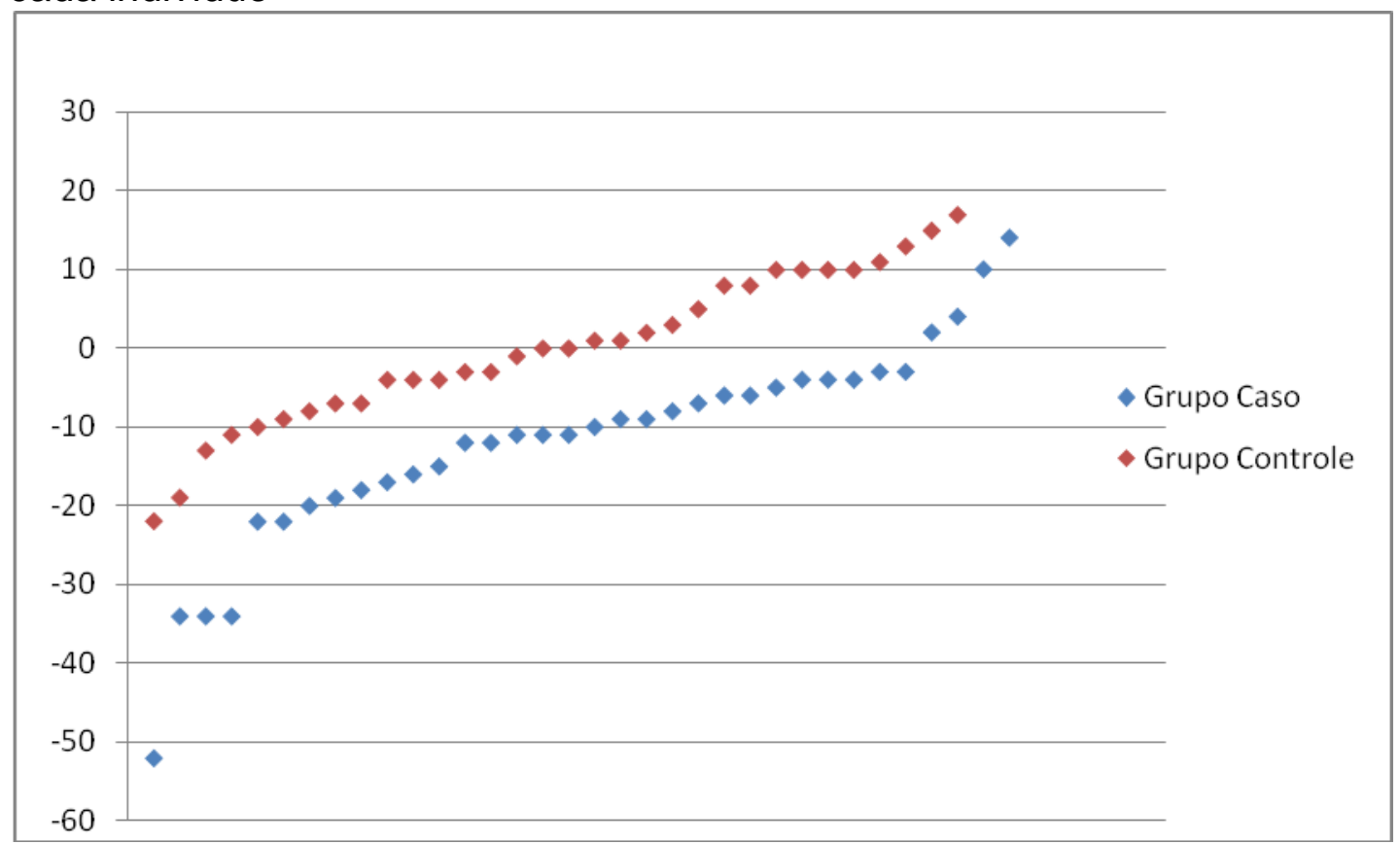

Notou-se que no grupo caso apenas quatro indivíduos $(11,7 \%)$ atingiram valores positivos (idades positivas), os demais (88,3\%) obtiveram idades negativas. A média dos valores da idade positiva das crianças com TDAH tipo combinado foi de 0,8 meses e a média dos valores da idade negativa foi de $-12,8$ meses.

Já no grupo controle, 15 crianças $(46,8 \%)$ alcançaram idades positivas e $17(53,1 \%)$ idades negativas. As médias dos valores dos indivíduos sem o transtorno foram: 3,8 meses para idade positiva e $-3,9$ meses para idade negativa. 
Os gráficos a seguir demonstram caso a caso a idade cronológica comparada com as idades motoras alcançadas em cada habilidade psicomotora $(4,5,6,7,8$ e 9) e com a idade motora geral (gráfico 10). Além disso, foram traçadas linhas de tendência a fim de acompanhar o desempenho psicomotor ao longo do avanço da idade cronológica.

Gráfico 4 - Desempenho da motricidade fina

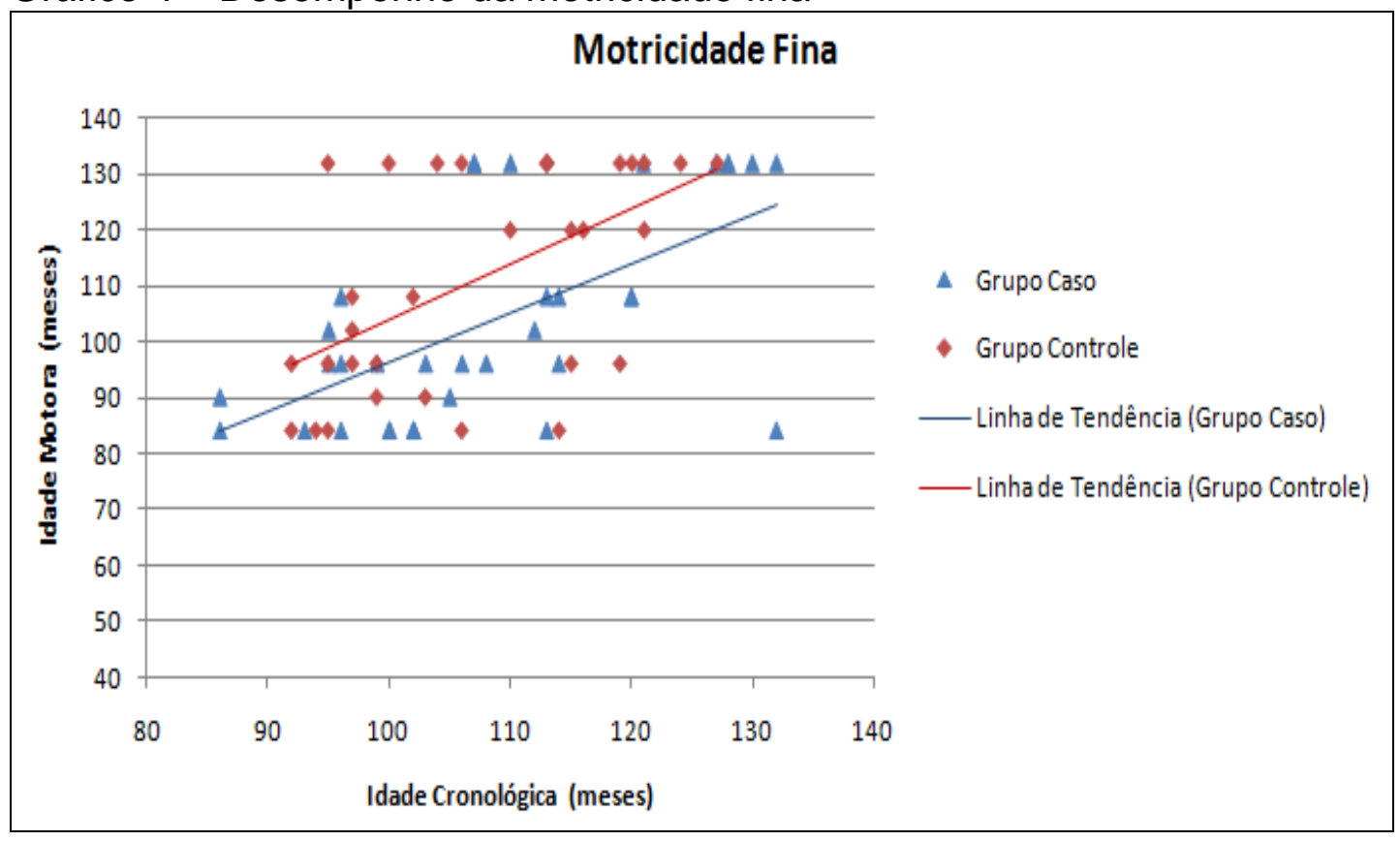


Gráfico 5 - Desempenho da motricidade global

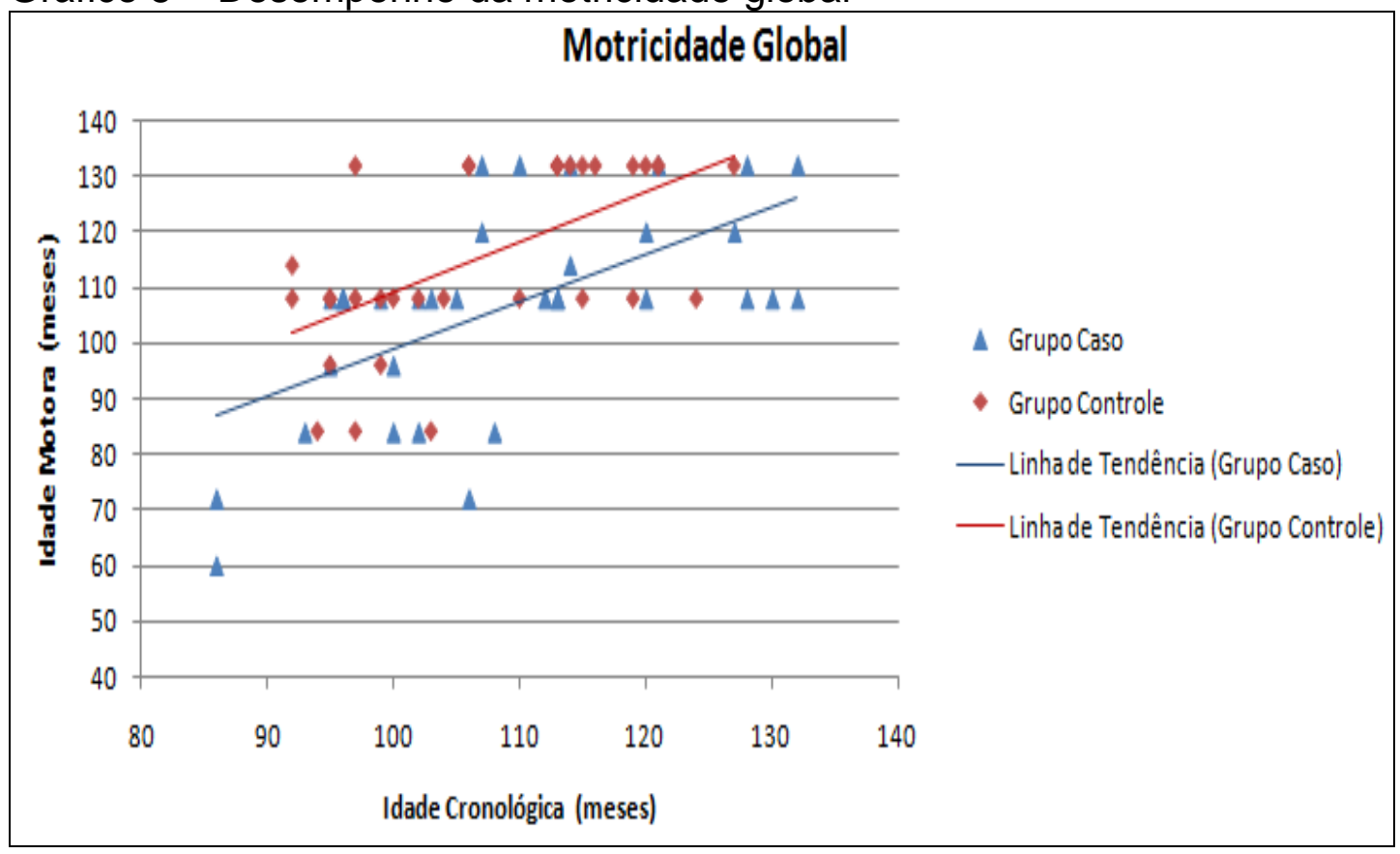

Gráfico 6 - Desempenho do equilíbrio

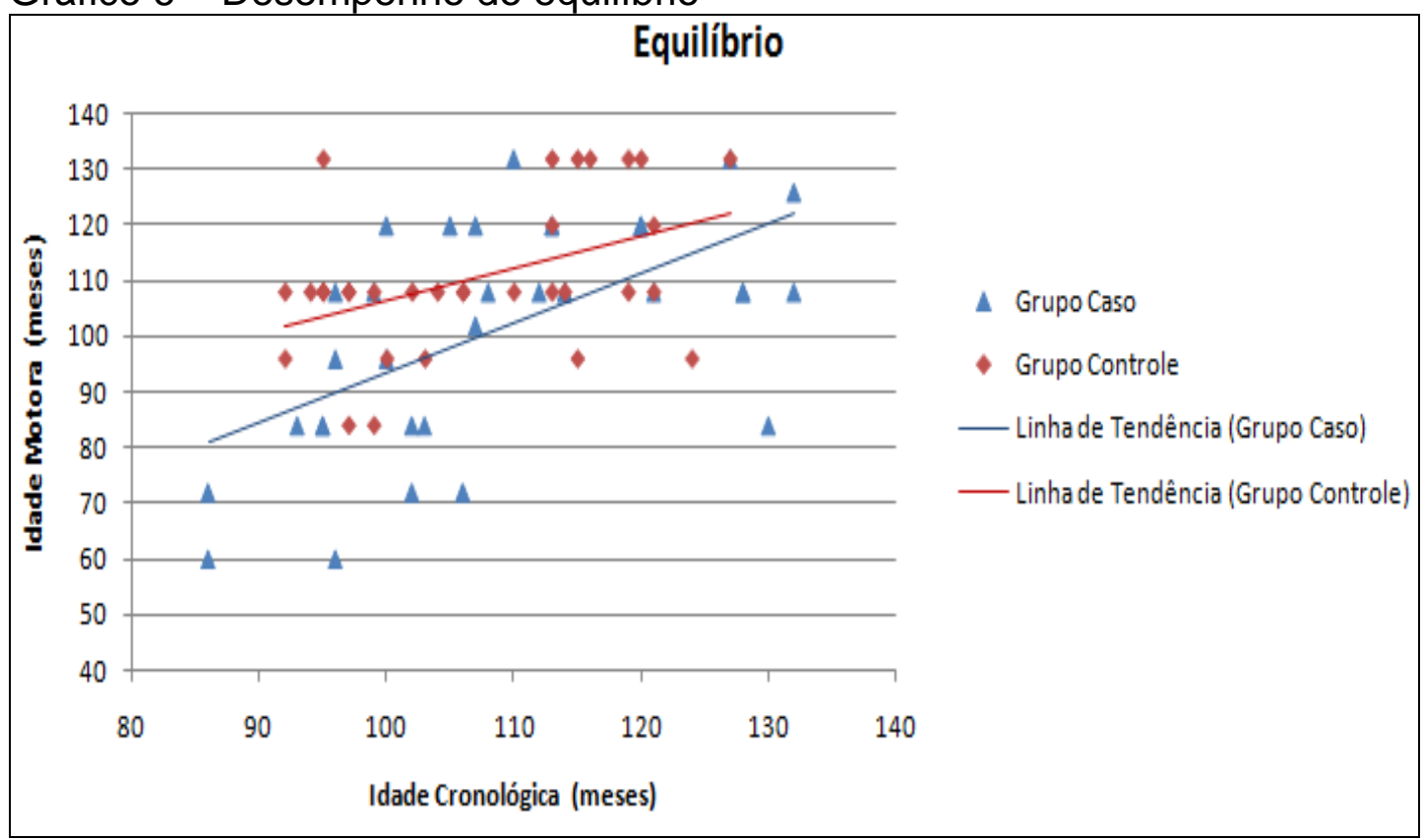


Gráfico 7 - Desempenho do esquema corporal

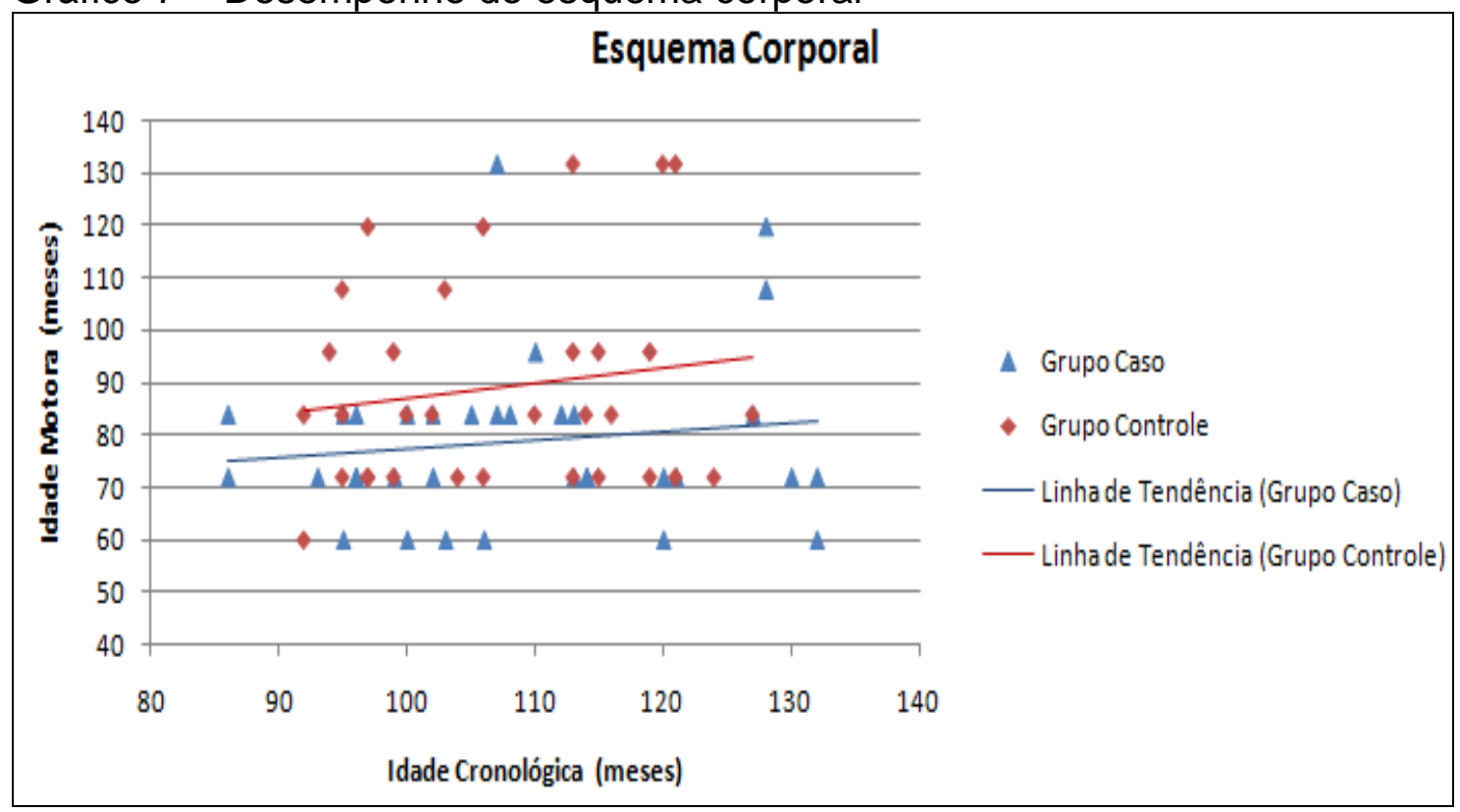

Gráfico 8 - Desempenho da organização espacial

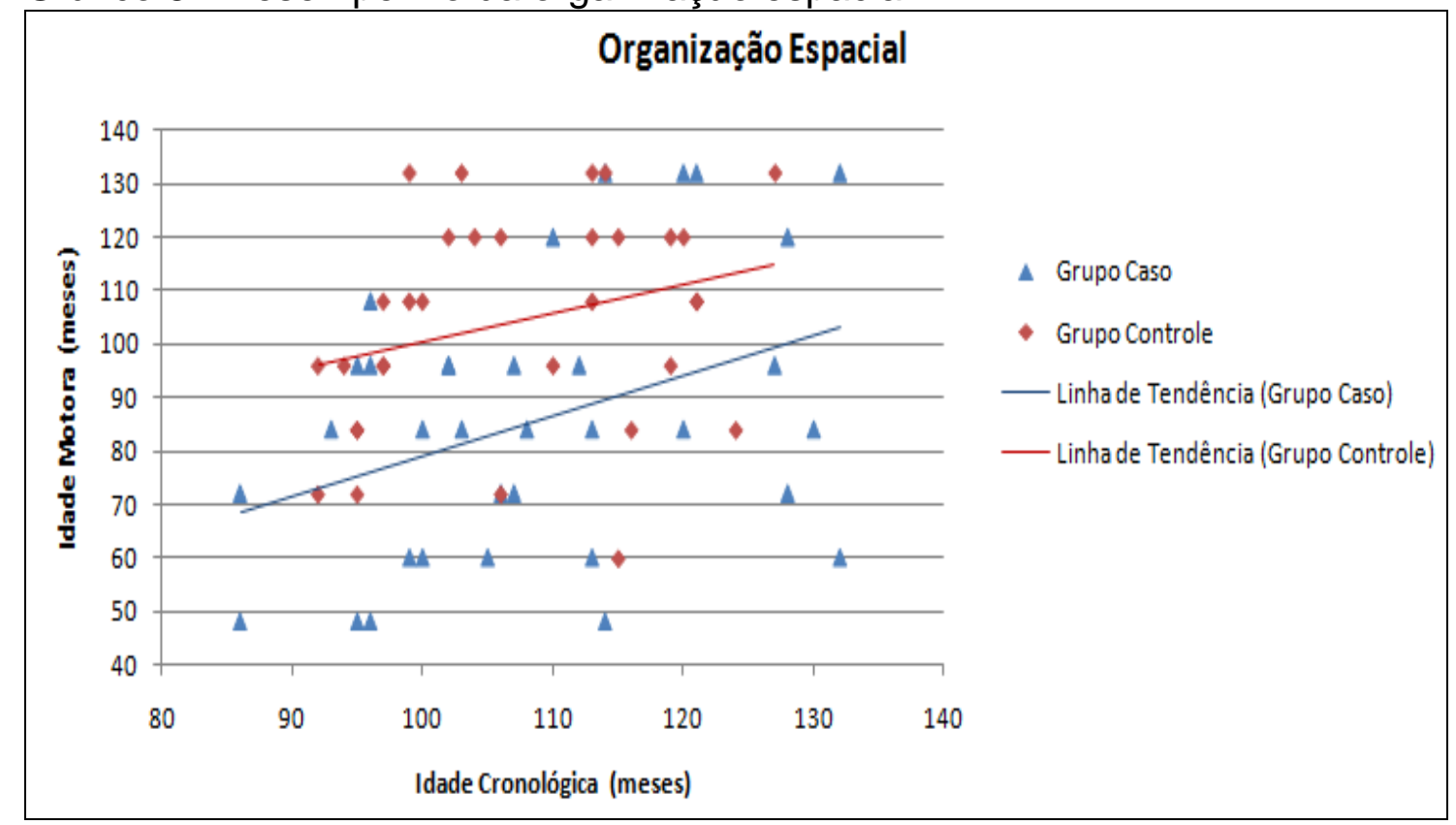


Gráfico 9 - Desempenho da organização temporal

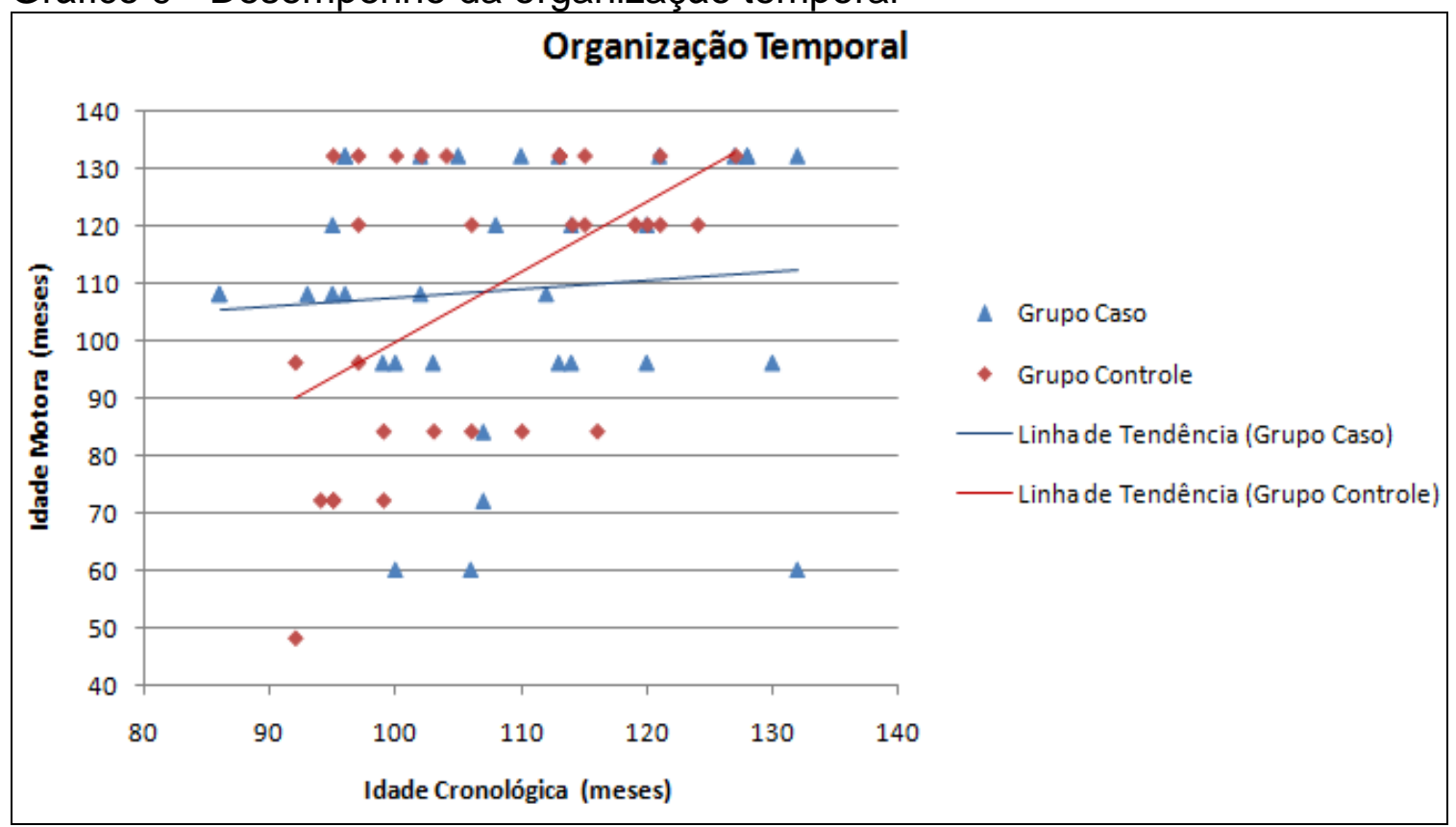

Gráfico 10-Desempenho da idade motora geral

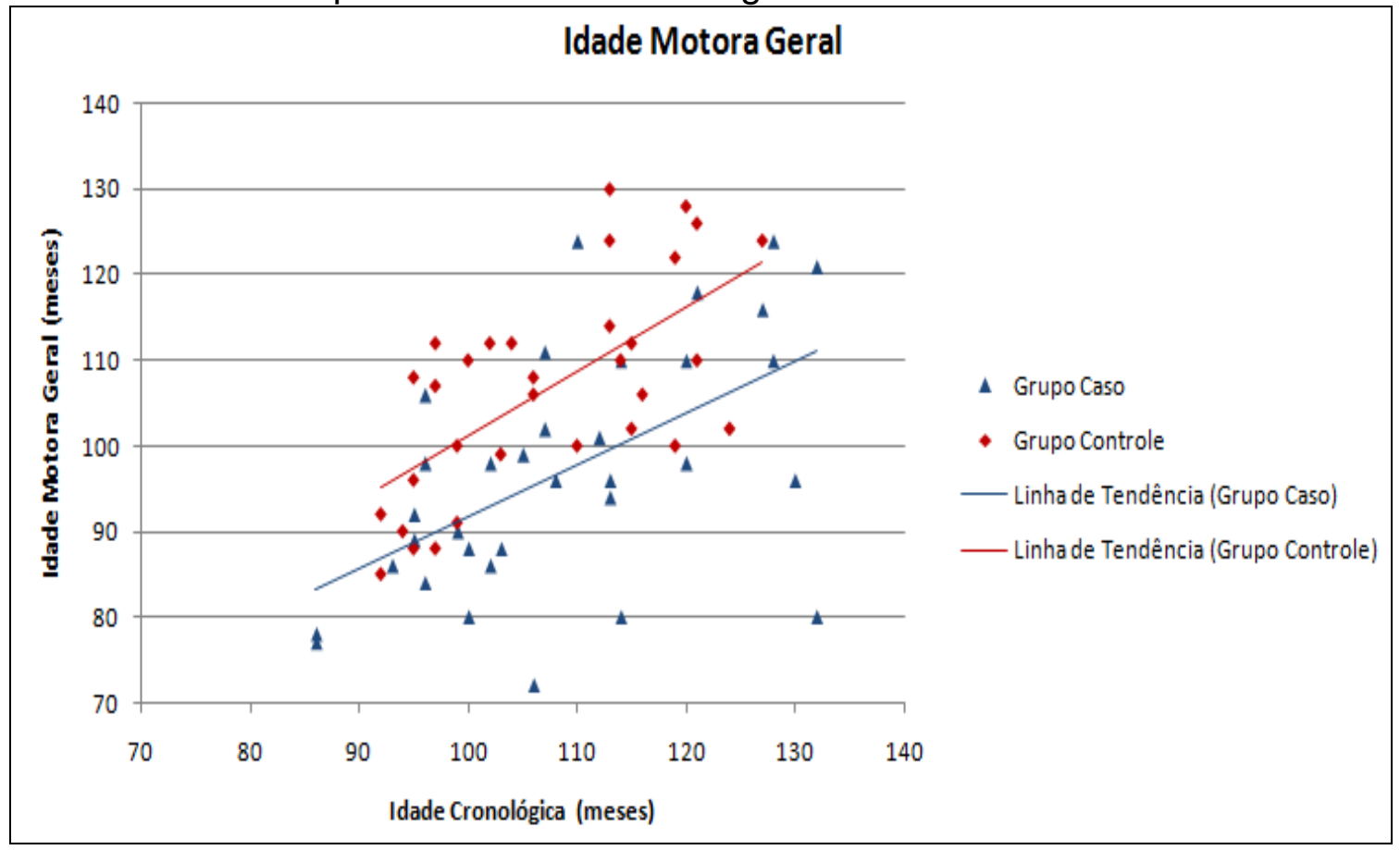




\section{DISCUSSÃO}

O perfil psicomotor delineado nesse estudo mostrou que meninos com TDAH do tipo combinado apresentam dificuldades no desempenho psicomotor quando comparados a meninos sem o transtorno, dado que corresponde ao encontrado na literatura (Poeta e Rosa Neto, 2007; Toniolo et al, 2009; Vidarte, Ezquerro e Giráldez, 2009). A EDM permitiu avaliar as diferentes habilidades psicomotoras e mostrou que há diferenças significativas entre os grupos.

Alterações expressivas das habilidades psicomotoras foram verificadas em $12 \%$ dos pacientes, o que determinou desenvolvimento motor abaixo da normalidade (muito inferior e inferior). Porém, se analisarmos que a classificação normal baixo determina idades negativas e, assim, revela dificuldades no desempenho de algumas habilidades, podemos considerar que $41 \%$ das crianças com TDAH manifestaram alterações motoras. Percentual que se assemelha aos valores entre $30 \%$ e $50 \%$ descritos em estudos clínicos e epidemiológicos (Kadesjo e Gillberg, 2001; Visser, 2003; Polatajko e Cantin, 2005; Magalhaes, Missiuna e Wong, 2006; Fliers et al, 2009).

Por outro lado, essa variação do desenvolvimento motor de baixo a alto, dentro dos índices de normalidade é esperada, pois a evolução de uma criança não se realiza de modo regular e progressivo, mas sim por saltos qualitativos que são seguidos de períodos de maturação. O ser humano se desenvolve em diversos ritmos, que dependem de suas próprias 
características e de experiências vivenciadas (Gallahue e Ozmun, 2003; OPAS, 2005).

Contudo, a idade negativa no grupo caso foi particularmente baixa (média de -12,8 meses), revelando a imaturidade de alguns aspectos do desenvolvimento psicomotor. Di Nucci também caracterizou o perfil psicomotor de dez crianças com TDAH, utilizando a EDM, e verificou que $40 \%$ da amostra apresentaram desenvolvimento normal médio, 40\% normal baixo e $20 \%$ inferior. Além disso, a idade motora geral foi menor que a idade cronológica em $90 \%$ dos seus casos e a média da idade negativa foi de aproximadamente 18 meses.

Essa imaturidade psicomotora pode estar relacionada ao atraso na maturação cerebral verificado pelo estudo de Shaw e colaboradores (2007), no qual a idade média em que o grupo TDAH atingiu o pico de maturação da espessura cortical foi de 10, 5 anos, significantemente mais tarde do que a idade média de 7,5 anos dos controles com desenvolvimento típico. O atraso foi mais proeminente em regiões pré-frontais ligadas à habilidade de inibir pensamentos e respostas indesejadas, controle executivo da atenção, avaliação das recompensas da ação, memória operacional e controle motor preciso e adequado à ação esperada.

O atraso na maturação cortical de aproximadamente três anos nas áreas pré-frontais demonstrado por Shaw et al (2007) pode explicar em parte o atraso no desenvolvimento motor de cerca de um ano observado em nosso estudo. Várias pesquisas têm verificado redução significativa no córtex pré-frontal nos pacientes com TDAH (Berquin et al, 1998; Giedd et al, 
2001; Castellanos, 2002; Seidman et al, 2006; Silva, 2010), mas muitas habilidades motoras estão ligadas às outras áreas frontais, tais como os córtex pré-motor e motor, relacionados a movimentos e atos motores elementares e sequenciais equivalentes a algumas provas motoras da EDM (lançar ou agarrar uma bola, saltar, entre outras).

Além disso, mesmo com amostras semelhantes quanto à idade, escolaridade e nível sócio-econômico nos grupos caso e controle, devemos considerar as influências ambientais. Afinal são distintas as possibilidades de uma criança, tenha ela um transtorno ou não, que vive em ambiente estimulante, daquela que se encontra num ambiente desprovida de recursos. Essa última poderá encontrar-se prejudicada tanto em seu desenvolvimento cognitivo quanto motor. Por isso, sugerimos outros estudos para a investigação sobre a influência dos fatores ambientais no desenvolvimento psicomotor de crianças com TDAH.

Embora, 53\% das crianças com TDAH apresentaram a classificação desenvolvimento motor normal médio, a média dos valores dos quocientes motores gerais determinou um índice de desenvolvimento motor normal baixo. Fato que pode ser esclarecido pela maior frequência de resultados baixos neste grupo. Concordamos com Vidarte, Ezquerro e Giráldez que o perfil psicomotor de meninos com e sem TDAH se classificam dentro da normalidade, mas aqueles com o transtorno têm pontuação menor e os seus níveis de execução em cada habilidade são piores.

A classificação do desenvolvimento motor como normal baixo coincide com os resultados de Poeta e Rosa Neto (2007), que também utilizaram a 
EDM para avaliar crianças com TDAH. Porém, em nosso estudo as menores médias foram verificadas no esquema corporal e organização espacial (inferior) e, no trabalho de Poeta e Rosa Neto(2007) foram na organização temporal (muito inferior), organização espacial e equilíbrio (inferior). Os resultados diferentes podem ser justificados pela escolha dos sujeitos envolvidos nas pesquisas, pois Poeta e Rosa Neto (2007) avaliaram crianças com indicadores do transtorno e não descreveram a presença ou ausência de comorbidades.

Atualmente não há concordância entre os estudos na determinação do tipo de comprometimento motor das crianças com TDAH, o que pode ser apontado pela discrepância nos métodos de avaliação e na população avaliada.

Pietcher, Piek e Hay (2003) referem que o tipo e o grau de dificuldade do movimento diferem entre os subtipos de TDAH. Acreditamos que não são apenas os testes escolhidos ou habilidades avaliadas que levam a estas diferenças, mas também a amostra selecionada, geralmente com comorbidades associadas e variações quanto ao sexo. Por isso, optamos por uma seleção mais criteriosa e homogênea do grupo caso, com a faixa etária condicionada pela idade média do diagnóstico do TDAH e pela escala de avaliação.

A fim de identificar as possíveis alterações psicomotoras, traçamos o perfil psicomotor de crianças com TDAH do tipo combinado.

Na motricidade fina houve concentração de indivíduos em ambos os grupos na classificação normal médio $(58,8 \%$ no grupo caso e $43,7 \%$ no 
grupo controle). Mas, 32,2\% das crianças com TDAH e $21,4 \%$ dos controles obtiveram baixo desempenho (muito inferior, inferior e normal baixo) e $8,7 \%$ dos indivíduos com o transtorno e 34,2\% sem o transtorno apresentaram alto desempenho (normal alto, superior e muito superior). Na motricidade global, a distribuição foi predominante na classe normal médio para os casos (50\%) e normal alto para os controles (40,6\%). Resultados baixos foram alcançados por $26,3 \%$ dos meninos com TDAH e $12,5 \%$ daqueles sem 0 transtorno e resultados altos por respectivamente $23,5 \%$ e $53 \%$.

Nosso estudo se assemelha ao de Pitcher, Piek e Hay (2003) que verificaram que meninos com TDAH do tipo combinado apresentam dificuldades significativas nas habilidades motoras globais. Também Tseng et al (2004) constataram que a atenção e o controle do impulso são preditores consistentes das habilidades motoras finas e globais em crianças com TDAH.

Em geral, as pesquisas descrevem fortes associações entre o TDAH e problemas na motricidade fina, outras indicam relações mais fortes entre esse transtorno e alterações na motricidade global (Pitcher et al. 2003; Visser 2003; Tseng et al. 2004; Fliers et al, 2008).

Quanto às idades motoras não houve diferenças estatisticamente significantes entre os grupos na motricidade fina e global, o que significa que a pontuação obtida em cada prova motora e expressa em meses, não foi diferente entre os grupos. Porém, os quocientes motores dessas habilidades motoras apresentaram diferenças estatísticas significantes, mostrando que quando a idade motora é relacionada à idade cronológica (através da divisão 
entre os valores e multiplicação por 100), o grupo caso demonstra desvantagem em relação ao grupo controle.

O comprometimento da motricidade fina e global pode ser explicado pelas alterações neurológicas em regiões corticais comumente encontradas no TDAH. No córtex pré-frontal: disfunções orbitais são associadas à desinibição social e comportamento impulsivo, o envolvimento da região dorsolateral causa déficits em organização, memória operacional, planejamento e atenção. Além disso, uma disfunção no circuito cerebelo tálamo - pré-frontal pode causar déficits de FEs, de inibição e de controle motor (Berquin et al, 1998; Castellanos et al, 2002; Seidman et al, 2006; Louzã-Neto, 2010).

No equilíbrio, a concentração de indivíduos com e sem TDAH foi na classificação normal médio (respectivamente 44,1\% e 46,8\%). Baixos desempenhos ocorreram em $41 \%$ do grupo caso e $15,6 \%$ do grupo controle, altos desempenhos apareceram, respectivamente, $14,6 \%$ e $37,4 \%$. Diferenças estatisticamente significantes foram constatadas entre os grupos na idade motora e no quociente motor desta habilidade e, as médias dos resultados foram mais baixas no grupo caso que no grupo controle.

Alterações de equilíbrio dinâmico, diadococinesia, destreza manual também foram observadas por Kroes e colaboradores (2002) e mostraram relações significativas com o aparecimento do TDAH.

Muitos estudos têm mostrado um volume cerebelar menor nos pacientes com TDAH em comparação a controles normais, outros demonstraram redução da atividade do cerebelo e do vermis (Berquin et al, 
1998; Giedd et al, 2001; Castellanos et al, 2002; Mackie et al, 2007). Dessa forma, o envolvimento cerebelar e circuitos associados pode ajudar a compreender as alterações de equilíbrio encontradas nas crianças com TDAH.

Assim como as alterações neurológicas e o atraso na maturação cerebral parecem ser mantidos ao longo do tempo, as linhas de tendência traçadas nos gráficos 4 e 5 mostraram que o atraso no desenvolvimento da motricidade fina e global tende a se manter com o aumento da idade cronológica nos meninos com TDAH, em cerca de dez meses em relação aos controles. Também o gráfico 6 aponta uma tendência à manutenção do atraso em relação aos controles com o avanço da idade cronológica nas habilidades de equilíbrio, porém com redução da idade negativa ao longo dos anos.

Apesar dessa tendência, não é possível afirmar que o atraso motor irá manter-se ou desaparecer na adolescência ou fase adulta, porque é possível que com o avanço da idade e com a maturação ocorram mecanismos de compensação neuronal, que propicie a aquisição de melhor desempenho motor. Estudos em adultos com TDAH sugerem um quadro biológico persistente, com anormalidades semelhantes às encontradas em crianças em relação ao córtex pré-frontal e cíngulo anterior (Bush et al, 1999; Seidman et al, 2006). Adultos com TDAH mostraram redução significante da atividade cerebelar e em regiões occipitais, além de uma tendência a uma diminuição da ativação em regiões do córtex pré-frontal (Valera et al, 2005). 
Concordamos com Gallahue e Ozmun (2003) que a maturação e a experiência juntamente com o crescimento e a adaptação estão interrelacionados com o desenvolvimento humano, em seus aspectos motores, cognitivos e afetivos.

Assim, os problemas relacionados ao planejamento, execução e ajuste do movimento podem levar a déficits no equilíbrio, na coordenação global e complexa do movimento, podendo interferir na aprendizagem escolar e nas atividades diárias.

O desenvolvimento das habilidades motoras globais, inclusive de equilíbrio, pode ser importante para a auto-estima e as habilidades motoras finas são essenciais a muitas atividades de vida diária, tais como vestir-se e escrever. A maioria dos testes motores baseia-se em atividades diárias e requerem atenção sustentada e controle de impulsos. Então, como as crianças com TDAH são mais propensas a apresentar dificuldades em suas ocupações diárias, os clínicos devem estar atentos às diferentes influências dos déficits de atenção, controle de impulso ou nível de atividade em diferentes áreas motoras (Tseng et al, 2004).

Essas dificuldades podem se refletir na recusa da exploração de novas habilidades e resistência a atividades diferentes de sua rotina, como uma maneira de proteger-se da frustração, especialmente em um evento coletivo.

Suzuki, Gugelmim e Soares (2005) referem que crianças com alterações do equilíbrio frequentemente afirmam que não gostam de realizar atividades físicas, devido à baixa performance nestas atividades, resultando 
em exclusão social.

Acrescentamos que não apenas os problemas no equilíbrio, mas da motricidade como um todo levam essas crianças a criar bloqueios com a prática de esportes e/ou atividades físicas, bem como ao envolvimento em aulas de educação física para não expor socialmente suas dificuldades, repercutindo em sua qualidade de vida. Essas questões não foram questionadas durante a avaliação, mas em muitos casos foram relatadas espontaneamente pelas crianças.

É importante ressaltar que a repercussão na qualidade vida das crianças com TDAH ocorrerá independente do envolvimento motor, já que o TDAH é um transtorno biopsicossocial. No entanto, a melhora do desempenho motor pode desenvolver habilidades e agir em seus sentimentos aprimorando assim sua auto-estima.

No esquema corporal, ambos os grupos se concentraram em baixos desempenhos: $91 \%$ das crianças com TDAH (41\% muito inferior) e $68,6 \%$ daquelas sem o transtorno (28,1\% muito inferior). $\mathrm{O}$ índice normal médio ocorreu em 5,8\% dos indivíduos do grupo caso e $15,6 \%$ do grupo controle e, as classificações normal alto, superior ou muito superior foram atingidas por respectivamente, 5,8\% e 15,6\%. Desse modo, a média dos valores obtidos nesta habilidade foi baixa em ambos os grupos, o que permitiu classificá-la como inferior no grupo caso e normal baixo no grupo controle. Ainda assim, os resultados obtidos pelas crianças com TDAH foram menores do que os dos controles e esse atraso tende a manter-se com o aumento da idade cronológica (gráfico 7). 
Mesmo que não seja possível especificar quais os motivos para esse fraco rendimento nas provas motoras do esquema corporal no grupo controle, a aplicação desses testes no grupo caso permitiu constatar que as crianças com TDAH apresentam desempenho motor nesta habilidade abaixo dos índices de normalidade, o que confirma a presença de significância estatística entre os grupos quanto às idades motoras. A pobre performance do grupo controle justifica a ausência de diferença estatística significante entre os grupos quanto aos quocientes motores.

Considerando que as provas motoras relacionadas ao esquema corporal envolvem basicamente imitação de gestos e teste de rapidez (traçar o maior número de riscos em uma folha quadriculada dentro do tempo estabelecido), as tarefas têm um caráter mais cognitivo que motor, pois requerem processos de atenção seletiva, memória, produção e execução.

Concordamos com Vidarte, Esquerro e Giráldez (2009) que as tarefas para avaliar a noção do corpo parecem implicar em diversas FEs, controladas por estruturas neurológicas que estão afetadas no TDAH, o que poderia explicar a dificuldade na execução dos testes.

$\mathrm{Na}$ organização espacial, as crianças com TDAH agruparam-se em $64,6 \%$ nas classes de baixo desempenho, $26,4 \%$ em normal médio e $8,8 \%$ em normal alto. Já entre os controles $37,3 \%$ atingiram baixos resultados, $34,3 \%$ normal médio e $28 \%$ altos resultados. Nessa habilidade observam-se as maiores diferenças entre os grupos, seja na significância estatística da idade e quociente motores, seja na diferença entre os grupos da média dos valores obtidos (18,5 meses na idade motora e 20,7 pontos no quociente 
motor), ou ainda na distância entre as linhas de tendência (gráfico 8).

O desenvolvimento da organização espacial permite à criança exercer os processos de localização, orientação, reconhecimento visuo-espacial, distância, superfície, volume e velocidade, além de ser considerada a base para processos matemáticos. Processos que também estão diretamente ligados às FEs comumente alteradas no TDAH, especialmente a memória operacional.

Quanto à organização temporal a distribuição entre as classes foi semelhante em ambos os grupos: o grupo caso dividiu-se em $26,3 \%$ nas classificações muito inferior, inferior e normal baixo, 35,2\% normal médio e $38,1 \%$ muito superior, superior e normal alto; o grupo controle apresentou-se respectivamente em $34,2 \%, 26,4 \%$ e $35,2 \%$. Por este motivo, não houve diferenças estatísticas significantes entre os grupos.

A estruturação temporal fornece à criança conceitos de ordem, duração, frequência e ritmo, o que implica em processos de percepção e memória de sucessão, processamento, armazenamento e rememorização, que são básicos aos conceitos linguísticos. Apesar de esses conceitos serem modificados pelo comprometimento das FEs, essas alterações não foram significativas na aplicação dos testes propostos pela EDM.

Isso pode refletir uma limitação da escala, uma vez que nas provas de organização temporal permite que se a criança falhe, seja feita uma nova demonstração e novo ensaio. Rosa Neto (2002) sugere que os períodos de tempo para a execução da tarefa são difíceis de apreciar, já que o que realmente importa é a sucessão correta. Além disso, o examinador precisa 
utilizar muito mais estímulos verbais e visuais para manter a atenção das crianças com TDAH durante as provas motoras do que para àquelas sem o transtorno.

No entanto, a linha de tendência da organização temporal (gráfico 9) sugere que os valores dessa habilidade se modificam pouco com o passar dos anos. Apesar de apresentar valores superiores aos controles antes dos nove anos (ao redor de 108 meses), após essa idade os valores tendem a se manter semelhantes. Diferentes dos controles que evoluem naturalmente, atingindo idades motoras próximas às idades cronológicas.

A avaliação da organização temporal é feita por meio de provas de linguagem, que envolvem basicamente repetição de frases, e a reprodução e a simbolização de estruturas espaciais. Compreende a capacidade de memorização e reprodução motora de estruturas rítmicas, observando a percepção auditiva e a memória de curto prazo.

A princípio a impulsividade parece facilitar o desempenho dos meninos com TDAH durante os testes, já que as sequências a serem repetidas são mais curtas, as estruturas rítmicas são mais simples e o número de estruturas a serem repetidas é menor. Por ser um método de avaliação atrativo e envolvente à criança, muitas vezes torna-se lúdico e estimula a criança com TDAH a querer mais e ansiar pela nova tarefa.

Porém, as provas vão ficando cada vez mais longas e passam a requerer a atenção sustentada e a memória operacional, ou seja, com o aumento da idade e a maturação neurológica, as estruturas nervosas deveriam tornar-se mais funcionais, o que parece não ocorrer nos meninos 
com TDAH.

Anormalidades no córtex pré-frontal e parietal, cerebelo, gânglios da base e circuitos associados levam a alterações no controle inibitório, memória operacional, tempo de reação e outras FEs importantes para o desenvolvimento do esquema corporal, organização espacial e organização temporal (Bush, Valera e Seidman, 2005; Valera et al, 2006; Seidman et al, 2006; Makris et al, 2007; Shaw et al, 2007).

Assim, o esquema corporal constitui a base para a aprendizagem das noções de espaço e tempo para a aplicação de tarefas escolares, desse modo o fato de as crianças não estarem estruturadas o suficiente no tempo e no espaço para o aprendizado da leitura e escrita, não possibilita uma relação positiva entre a estrutura espaço-temporal e a aprendizagem (Medina-Papst e Marques, 2010).

Todos estes prejuízos motores e cognitivos refletem-se na idade motora geral inferior à cronológica, ou seja, num atraso no desenvolvimento psicomotor (gráfico 10), que é mantido com o aumento da idade cronológica e tende a ficar mais evidente após os 10 anos (120 meses).

Em nosso estudo, a maioria dos pacientes com TDAH (88\%) se classificou dentro de índices de normalidade. De fato, eles conseguem realizar as tarefas propostas, tais como lançar uma bola, amassar um papel, saltar, entre outros. Porém, seu desempenho e sua destreza são de qualidade inferior a das crianças sem o transtorno. O número de tentativas para que ele execute a prova é maior, mas ainda dentro do proposto pela escala. Por exemplo, na prova caminhar em linha reta, o avaliado deve 
percorrer dois metros em linha reta, posicionando o calcanhar de um pé com a ponta de outro pé, são possíveis três tentativas para cada pé. Geralmente, a criança sem o transtorno consegue executar logo na primeira tentativa, a criança com TDAH irá realizar duas ou três tentativas.

Como a análise do desempenho não é qualitativa e a testagem é feita de modo individual, sugerimos que esses fatores possam ter amenizado a avaliação dos problemas motores. Além disso, a ausência do registro do número de tentativas para a execução das tarefas em ambos os grupos pode ser considerada uma limitação de nosso estudo.

Concordamos com publicações nacionais que esta escala pode ser uma ferramenta útil à avaliação do desenvolvimento psicomotor e um roteiro de estimulação eficaz em programas de intervenção e a orientações aos familiares de crianças com TDAH (Rosa Neto, 2002; Poeta e Rosa Neto, 2004; Suzuki, Gugelmim e Soares, 2005; Silveira et al, 2006; Amaro et al, 2009; Rosa Neto et al, 2010ab; Corazza et al, 2010). Para se traçar o perfil psicomotor foi necessário um instrumento de avaliação sistemático que abrangesse todas as habilidades psicomotoras do desenvolvimento humano, como a EDM.

Desse modo, a vigilância atenta e precisa dos padrões psicomotores das crianças com TDAH pode oferecer subsídios aos profissionais das áreas de saúde e educação para o estabelecimento e direcionamento de intervenções adequadas às necessidades e interesses reais do paciente e da família.

Concordamos com Medina-Papst e Marques (2010) que a observação 
dos padrões motores contribui de forma preventiva e reeducativa para amenizar ou excluir fatores impeditivos do potencial de aprendizagem da criança. Há uma preocupação interdisciplinar quanto à detecção precoce das dificuldades escolares, avaliação do nível de desenvolvimento da criança e a necessidade de proposta de intervenção com atividades adequadas, almejando resultados benéficos à criança e que tendem a reduzir problemas e maiores transtornos futuros nos anos escolares. É essencial o conhecimento do profissional ligado ao ensino infantil sobre o processo de desenvolvimento e aprendizagem motora para que este se fundamente na seleção de atividades escolares.

O conhecimento de uma desordem crônica permite o preparo do ambiente familiar e social no sentido de propiciar ao indivíduo acometido a melhor qualidade de vida possível. O desenvolvimento psicomotor pode dar indícios da integridade cognitiva do indivíduo. Crianças com fatores de risco para desvios do desenvolvimento psicomotor, ou aquelas nas quais estes desvios são observados previamente ao ingresso na escola, devem ter um acompanhamento e uma avaliação mais detalhada (Araújo, 2002).

Ao considerarmos que os fatores de risco para o desenvolvimento incluem várias condições biológicas ou ambientais que impedem o pleno desenvolvimento da criança, concluímos com este estudo que o TDAH pode constituir um fator de risco para o desenvolvimento psicomotor infantil. Contudo, as alterações motoras podem ser preditoras do TDAH, sua detecção precoce pode constituir sinais de alerta ao diagnóstico do TDAH.

Vidarte, Ezquerro e Giráldez (2009) sugerem que o diagnóstico e 
seguimento da dimensão motora nos pacientes com TDAH, em sua maioria são superficiais e contraditórios, pois os profissionais que geralmente assumem essa função são médicos e psicólogos, que tendem a direcionar as condutas terapêuticas de acordo com sua formação profissional, que em ambos os casos não inclui a qualificação necessária para realizar a correta avaliação motora do paciente, nem mesmo desenhar um programa de exercícios adequados.

Nesse sentido, a atuação do fisioterapeuta faz-se necessária, uma vez que, suas atribuições profissionais incluem preservar, manter, desenvolver ou restaurar a funcionalidade, além de ter por objeto de estudos o movimento humano em todas as suas formas de expressão e potencialidades, tanto nas alterações patológicas quanto nas repercussões psíquicas e orgânicas (CREFITO, 2010).

Também o terapeuta ocupacional torna-se importante nos processos de avaliação e intervenção motora, pois reúne tecnologias orientadas para a emancipação e autonomia de pessoas que tenham dificuldades na inserção à participação na vida social. $\mathrm{A}$ atividade é seu instrumento terapêutico, que seleciona, analisa e adapta a atividade a cada indivíduo e situação, dividindo-a em fases, observando e determinando os aspectos motores, psíquicos, sensório-perceptivos, socioculturais, cognitivos e funcionais necessários à realização da mesma (CREFITO, 2010).

O educador físico pode contribuir na abordagem com os pacientes com TDAH por ser especialista em atividades físicas e ter como propósitos prestar serviços que favoreçam o desenvolvimento da educação e da saúde. 
Dessa forma, contribui para a capacitação e/ou restabelecimento de níveis adequados de desempenho e condicionamento fisiocorporal, visando à consecução do bem-estar e da qualidade de vida, da consciência, da expressão e estética do movimento, contribuindo ainda, para consecução da autonomia, da auto-estima, da cooperação, da solidariedade, da integração, da cidadania, das relações sociais. (CREFSP, 2010).

Além disso, todos os profissionais da saúde ou da educação que se especializem em psicomotricidade, ou seja, na ciência que tem como objeto de estudo o homem através do seu corpo em movimento e em relação ao seu mundo interno e externo, pode atuar de forma positiva no TDAH.

Qualquer que seja a especialidade do profissional que irá desenvolver a intervenção motora pode utilizar o lúdico como recurso auxiliar nas terapias. As atividades lúdicas têm uma função motivadora, com uma aprendizagem diferente, que ajuda os participantes a desenvolver confiança em si mesmos e em suas capacidades, leva as crianças a desenvolverem percepções sobre outras pessoas e a compreender as exigências bidirecionais de expectativa e tolerância, além de oportunidades para explorar conceitos como liberdade, existentes implicitamente em muitas situações lúdicas, o que eventualmente levam a pontos de transposição no desenvolvimento da independência.

Esse tipo de interação permite que a criança aprenda podendo apresentar evolução em suas capacidades psicomotoras. Porém não é qualquer tipo de interação que é válida e nem todas as crianças com TDAH precisarão deste tipo de intervenção. Afinal a criança é um ser único e deve 
ser respeitada com suas limitações e características próprias. Há que se valorizar todo seu potencial, além das sensações captadas pela criança e a motivação que se estabelece para a interação com o ambiente.

O fato de se proporcionar o maior número de experiências motoras e psicossociais a essas crianças estará ajudando a diminuir o comprometimento de habilidades, inclusive as escolares (Rosa Neto et al, 2010a). Ao reduzir o impacto dos efeitos negativos do risco e permitir o estabelecimento e a manutenção da auto-estima abrem-se oportunidades para o desenvolvimento (Maria-Mengel, 2007).

Desse modo, é essencial a inclusão dos profissionais fisioterapeutas, terapeutas ocupacionais e educadores físicos na equipe multidisciplinar que direciona a assistência aos pacientes com TDAH. Além disso, pais e professores devem ser instruídos a administrar os problemas motores para amenizar os impactos, principalmente em sua auto-estima e qualidade de vida.

O conhecimento sobre o perfil psicomotor das crianças com TDAH pode auxiliar na definição das propostas terapêuticas, ampliando a rede de profissionais vinculados à assistência desses pacientes, a fim de minimizar os prejuízos em sua qualidade de vida.

Atualmente as crianças com TDAH já possuem o acompanhamento multidisciplinar, com tratamento medicamentoso, terapias cognitivocomportamentais, psicoterapia, tratamento fonoaudiológico, psicopedagógico, entre outros, indicando que o olhar para essa criança já é abrangente. Somando a essas terapias a inclusão do acompanhamento 
psicomotor, com profissionais capacitados para esse fim, a abordagem passa a ser mais ampla, atuando de forma positiva no seu bem-estar físico, mental e social.

Qualquer que seja a especialidade, os profissionais responsáveis pela avaliação e tratamento destes pacientes devem ressaltar as dificuldades enfrentadas pela própria criança, enfatizando a importância e o impacto positivo que o apoio familiar e social pode ter sobre o manejo do problema. Estimulada e apoiada, a criança participa ativamente do tratamento, evidenciando frequentemente criatividade e entusiasmo no manejo das dificuldades associadas ao TDAH. 


\section{CONCLUSÃO}

O perfil psicomotor dos meninos com TDAH tipo combinado, sem comorbidades, exceto o TOD, foi considerado com pior desempenho em relação aos controles. Ocorreram alterações significativas, com desempenho inferior e muito inferior em $12 \%$ do grupo caso, enquanto nenhum participante do grupo controle apresentou essa classificação.

As alterações psicomotoras mais expressivas, evidenciando uma desvantagem entre o grupo com TDAH em relação ao controle foram: idade motora geral, quociente motor geral, equilíbrio, organização espacial, motricidade fina e global. 
7. ANEXOS

\section{Anexo 1 - Aprovação CAPPesq}

\section{APROVAÇÃO}

A Comissão de Ética para Análise de Projetos de Pesquisa CAPPesa da Diretoria Clínica do Hospital das Clínicas e da Faculdade de Medicina da Universidade de São Paulo, em sessão de 04/02/2009, APrOVOU O Protocolo de Pesquisa n 0573/08, intitulado: "PERFIL PSICOMOTOR DE CRIANÇAS COM TRANSTORNO DE DÉFICIT DE ATENÇÃO / HIPERATIVIDADE' apresentado pelo Departamento de PEDIATRIA, inclusive o Termo de Consentimento Livre e Esclarecido.

Cabe ao pesquisador elaborar e apresentar à CAPPesq, os relatórios parciais e final sobre a pesquisa (Resolução do Conselho Nacional de Saúde $n^{\circ} 196$, de 10/10/1996, inciso IX.2, letra "c").

Pesquisador (a) Responsável: Prof. Dr. Erasmo Barbante Casella Pesquisador (a) Executante: JULIANA BARBOSA GOULARDINS

CAPPesq, 05 de Fevereiro de 2009

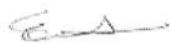

Prof. Dr. Eduardo Massad Presidente da Comissão de Ética para Análise de Projetos de Pesquisa

Comissão de Ética para Análise de Projetos de Pesquisa do HCFMUSP e da FMUSP Diretoria Clínica do Hospital das Clínicas da Faculdade de Medicina da Universidade de Săo Paulo Rua Ovidio Pires de Campos 225, $5^{\circ}$ andar - CEP 05403010 - São Paulo - SP Fone: 01130696442 Fax: 01130696492 e-mail. cappesq@hcnet.usp.br/ secretariacappesq2@hcnet.usp.br 
Anexo 2 - Termo de Anuência da Escola Estadual Keizo Ishihara
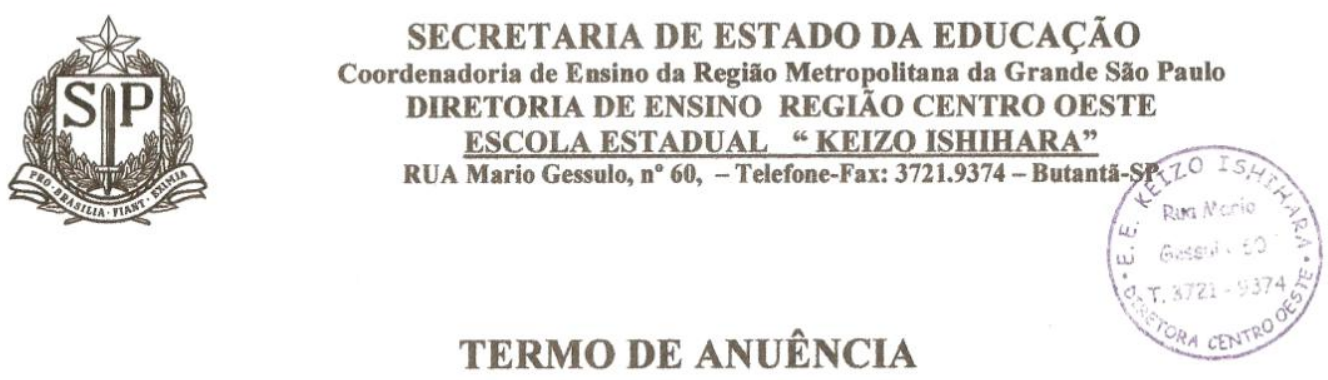

Declaramos, para os devidos fins, que concordamos em receber a aluna Juliana Barbosa Goulardins sob orientação do pesquisador principal Dr. Erasmo Barbante Casella, na Escola Estadual Keizo Ishihara para realização de pesquisa referente à tese de mestrado com tema "Perfil psicomotor de crianças com transtorno de déficit de atenção/hiperatividade", desenvolvido pelo Departamento de Pediatria da Faculdade de Medicina da Universidade de São Paulo.

É sabido que o estudo citado acima não gera danos e riscos para alunos, pais e/ou professores. Ficaram claros para mim quais são os propósitos do estudo, os procedimentos a serem realizados, as garantias de confidencialidade e de esclarecimento permanentes, ficou claro também que a participação do estabelecimento de ensino é isenta de despesas.

São Paulo, 22 de Dezembro de 2008.

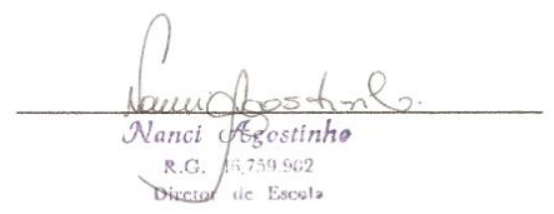




\section{Anexo 3 - Termo de Anuência da Escola Estadual Eduardo Carlos Pereira}

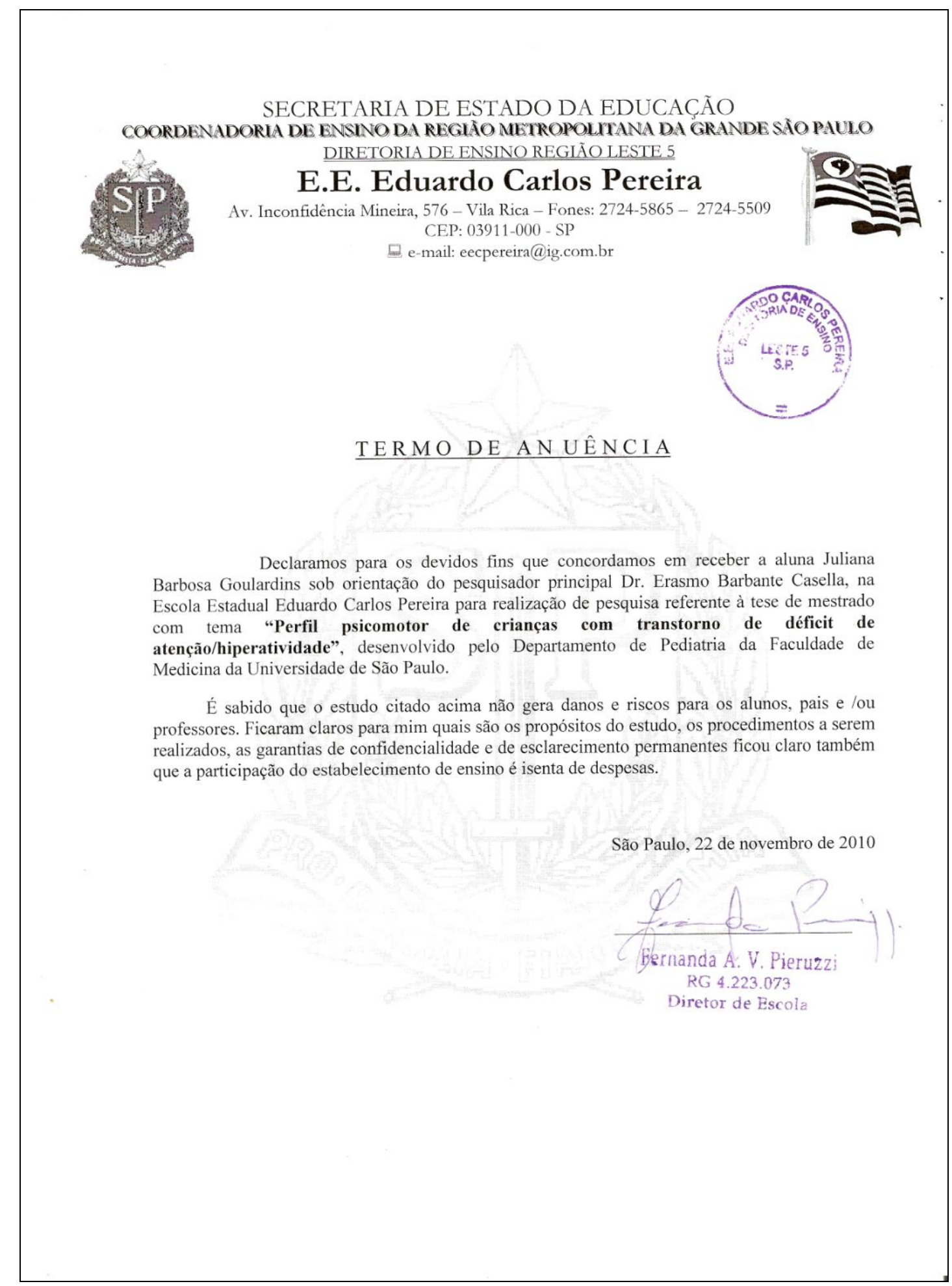




\section{Anexo 4 - Termo de Consentimento Livre e Esclarecido do grupo caso}

Caro (a) Senhor (a), estamos desenvolvendo uma pesquisa que tem como tema "Perfil psicomotor de crianças com Transtorno de Déficit de Atenção/Hiperatividade".

O objetivo deste estudo consiste em avaliar o perfil psicomotor dos pacientes com TDAH, verificando as possíveis dificuldades em habilidades como motricidade global e fina, equilíbrio, esquema corporal, organização espacial e temporal.

Esta pesquisa está sendo realizada no ambulatório de Distúrbios do Aprendizado do Instituto da Criança e no Ambulatório de TDAH do Instituto Central do HCFMUSP.

Mas para que seja realizada é muito importante a sua participação e de seu filho para levantamento destes dados, para que possamos observar se há prejuízo nas habilidades psicomotoras das crianças com TDAH.

O estudo contém uma avaliação específica, com testes e provas motoras, que será realizada na própria escola.

Em qualquer etapa do estudo o voluntário terá acesso aos profissionais responsáveis pela pesquisa para esclarecimento de eventuais dúvidas.

O pesquisador principal é Dr. Erasmo Barbante Casella que pode ser encontrado na Av. Dr. Enéas Carvalho de Aguiar, ㄲo 697. Tel: 3069-8500. Se você tiver alguma consideração ou dúvida sobre a ética da pesquisa, entre em contato com o Comitê de Ética em Pesquisa (CEP) - Rua Ovídio Pires de Campos, 225 - 5aar - tel: 3069-6442 ramais 16, 17, 18 ou 20, FAX: 3069-6442 ramal 26 - E-mail: cappesq@hcnet.usp.br

Não haverá ressarcimento financeiro ao voluntário pela participação na pesquisa. É garantida ao voluntário a retirada de consentimento a qualquer momento e deixar de participar do estudo. As informações obtidas serão analisadas em conjunto com outros pacientes, não sendo divulgada a identificação de nenhum indivíduo. Os dados coletados serão realizados somente para esta pesquisa. O voluntário terá o direito de ser mantido atualizado sobre os resultados parciais da pesquisa.

Acredito ter sido suficientemente informado a respeito das informações que li ou que foram lidas para mim, descrevendo o estudo "Perfil psicomotor de crianças com Transtorno de Déficit de Atenção/Hiperatividade".

Discuti com o Dr. Erasmo Barbante Casella sobre a minha decisão em participar nesse estudo. Ficaram claros para mim quais são os propósitos do estudo, os procedimentos a serem realizados, os desconfortos e riscos, as garantias de confidencialidade e de esclarecimento permanentes. Ficou claro também que minha participação é isenta de despesas e que tenho garantia do acesso a tratamento hospitalar quando necessário. Concordo com o estudo e poderei retirar o meu consentimento a qualquer momento, antes ou durante o mesmo, sem penalidades ou prejuízo ou perda de qualquer benefício que possa o voluntário ter adquirido ou no meu atendimento neste serviço. 


\section{Anexo 5 - Termo de Consentimento Livre e Esclarecido do grupo controle}

Caro (a) Senhor (a), estamos desenvolvendo uma pesquisa que tem como tema "Perfil psicomotor de crianças com Transtorno de Déficit de Atenção/Hiperatividade" (TDAH).

O objetivo deste estudo consiste em avaliar o perfil psicomotor dos pacientes com TDAH, verificando as possíveis dificuldades em habilidades como motricidade global e fina, equilíbrio, esquema corporal, organização espacial e temporal.

Esta pesquisa está sendo realizada no ambulatório de Distúrbios do Aprendizado do Instituto da Criança e no Ambulatório de TDAH do Instituto Central do HCFMUSP.

Mas para que seja realizada é muito importante a sua participação para levantamento destes dados, pois há a necessidade de comparação das respostas dos pacientes e seus responsáveis com a de crianças que não apresentem nenhum distúrbio físico e neuropsiquiátrico, para que possamos observar se há prejuízo nas habilidades psicomotoras das crianças com TDAH. Por este motivo a importância de sua participação e de seu filho.

O estudo contém uma avaliação específica, com testes e provas motoras, que será realizada na própria escola.

Em qualquer etapa do estudo o voluntário terá acesso aos profissionais responsáveis pela pesquisa para esclarecimento de eventuais dúvidas.

O pesquisador principal é Dr. Erasmo Barbante Casella que pode ser encontrado na Av. Dr. Enéas Carvalho de Aguiar, no 697. Tel: 3069-8500. Se você tiver alguma consideração ou dúvida sobre a ética da pesquisa, entre em contato com o Comitê de Ética em Pesquisa (CEP) - Rua Ovídio Pires de Campos, 225 - 5aandar - tel: 3069-6442 ramais 16, 17, 18 ou 20, FAX: 3069-6442 ramal 26 - E-mail: cappesq@hcnet.usp.br

Não haverá ressarcimento financeiro ao voluntário pela participação na pesquisa. É garantida ao voluntário a retirada de consentimento a qualquer momento e deixar de participar do estudo. As informações obtidas serão analisadas em conjunto com outros pacientes, não sendo divulgada a identificação de nenhum indivíduo. Os dados coletados serão realizados somente para esta pesquisa. O voluntário terá o direito de ser mantido atualizado sobre os resultados parciais da pesquisa.

Acredito ter sido suficientemente informado a respeito das informações que li ou que foram lidas para mim, descrevendo o estudo "Perfil psicomotor de crianças com Transtorno de Déficit de Atenção/Hiperatividade".

Discuti com o Dr. Erasmo Barbante Casella sobre a minha decisão em participar nesse estudo. Ficaram claros para mim quais são os propósitos do estudo, os procedimentos a serem realizados, os desconfortos e riscos, as garantias de confidencialidade e de esclarecimento permanentes. Ficou claro também que minha participação é isenta de despesas e que tenho garantia do acesso a tratamento hospitalar quando necessário. Concordo com o estudo e poderei retirar o meu consentimento a qualquer momento, antes ou durante o mesmo, sem penalidades ou prejuízo ou perda de qualquer benefício que possa o voluntário ter adquirido ou no meu atendimento neste serviço. 


\section{Anexo 6 - SNAP IV}

Para cada item, escolha a coluna que melhor descreve o (a) aluno (a) (MARQUE UM X):

\begin{tabular}{|c|c|c|c|c|}
\hline & $\begin{array}{l}\text { Nem um } \\
\text { pouco }\end{array}$ & $\begin{array}{l}\text { Só um } \\
\text { pouco }\end{array}$ & Bastante & Demais \\
\hline $\begin{array}{l}\text { 1. Não consegue prestar muita atenção a } \\
\text { detalhes ou comete erros por descuido nos } \\
\text { trabalhos da escola ou tarefas. }\end{array}$ & & & & \\
\hline $\begin{array}{l}\text { 2. Tem dificuldade de manter a atenção em } \\
\text { tarefas ou atividades de lazer. }\end{array}$ & & & & \\
\hline $\begin{array}{l}\text { 3. Parece não estar ouvindo quando se fala } \\
\text { diretamente com ele. }\end{array}$ & & & & \\
\hline $\begin{array}{l}\text { 4. Não segue instruções até o fim e não termina } \\
\text { deveres de escola, tarefas ou obrigações. }\end{array}$ & & & & \\
\hline $\begin{array}{l}\text { 5. Tem dificuldade para organizar tarefas e } \\
\text { atividades. }\end{array}$ & & & & \\
\hline $\begin{array}{l}\text { 6. Evita, não gosta ou se envolve contra a } \\
\text { vontade em tarefas que exigem esforço mental } \\
\text { prolongado. }\end{array}$ & & & & \\
\hline $\begin{array}{l}\text { 7. Perde coisas necessárias para atividades (p. } \\
\text { ex: brinquedos, deveres da escola, lápis ou } \\
\text { livros). }\end{array}$ & & & & \\
\hline 8. Distrai-se com estímulos externos. & & & & \\
\hline 9. É esquecido em atividades do dia-a-dia. & & & & \\
\hline $\begin{array}{l}\text { 10. Mexe com as mãos ou os pés ou se remexe } \\
\text { na cadeira. }\end{array}$ & & & & \\
\hline $\begin{array}{l}\text { 11. Sai do lugar na sala de aula ou em outras } \\
\text { situações em que se espera que fique sentado. }\end{array}$ & & & & \\
\hline $\begin{array}{l}\text { 12. Corre de um lado para outro ou sobe demais } \\
\text { nas coisas em situações em que isto é } \\
\text { inapropriado. }\end{array}$ & & & & \\
\hline $\begin{array}{l}\text { 13. Tem dificuldade em brincar ou envolver-se } \\
\text { em atividades de lazer de forma calma. }\end{array}$ & & & & \\
\hline $\begin{array}{l}\text { 14. Não pára ou freqüentemente está a "mil por } \\
\text { hora". }\end{array}$ & & & & \\
\hline 15. Fala em excesso. & & & & \\
\hline $\begin{array}{l}\text { 16. Responde as perguntas de forma precipitada } \\
\text { antes de elas terem sido terminadas. }\end{array}$ & & & & \\
\hline 17. Tem dificuldade de esperar sua vez. & & & & \\
\hline $\begin{array}{l}\text { 18. Interrompe os outros ou se intromete (p.ex. } \\
\text { mete-se nas conversas / jogos). }\end{array}$ & & & & \\
\hline
\end{tabular}




\section{Anexo 7 - Protocolo de consulta inicial}

\section{INSTITUTO DA CRIANÇA DO HC-FMUSP \\ AMBULATÓRIO DE DISTÚRBIO DE APRENDIZADO ANPE 6}

Data:

Nome:

REG:

Idade:

DN:

Sexo ( ) Masc ( ) Fem

Informante:

Contato: End.:

Tel:

Anamnese:

1) Como foi encaminhado para avaliação. Queixa dos Pais, Escola, Psicóloga, etc.?

2)QD:

3)HPMA:

ISDA:

INATENÇÃO:

a) C/ freq. deixa de prestar atenção a detalhes ou comete erros, por descuido, nas tarefas escolares, no trabalho ou outras atividades.

SIM ? NÃO ?

b) C/ freq. tem dificuldade em manter a atenção em tarefas ou brincadeiras.

SIM ? NÃO ?

i. $\quad C /$ freq. parece não ouvir o q. Ihe é dito diretamente

SIM ? NÃO ?

ii. C/ freq. não segue instruções e deixa de completar trabalhos escolares ou tarefas domésticas (mas a recusa, não decorre de um comportamento desafiador ou de falta de compreensão das instruções)

SIM ? NÃO ?

iii. C/ freq. tem dificuldade em organizar tarefas e atividades
SIM ?
NÃO ?

iv. C/ freq. evita ou reluta em começar tarefas q. exigem grd.esforço mental (c/o trabalhos escolares ou deveres de casa)
SIM ?
NÃO ?

v. C/ freq. perde objetos essenciais às tarefas ou atividades (p. ex. canetas, lápis, cadernos, brinquedos)
SIM ?

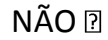

vi. $\quad \mathrm{C} /$ freq. se distrai facilmente por estímulos externos

$$
\text { SIM ? NÃO ? }
$$

vii. C/ freq. é esquecido nas suas atividades diárias.
SIM ?
NÃO ?

HIPERATIVIDADE:

viii. Remexe as mãos ou os pés ou se contorce no seu lugar

$$
\text { SIM ? NÃO ? }
$$

ix. Sai do seu lugar na sala de aula ou em outras situações em q. deve permanecer sentado.

$$
\text { SIM ? NÃO ? }
$$

x. Corre ao redor dos móveis ou os escala, excessivamente, em situações inadequadas (em adolescentes ou adultos pode estar limitado a sentimentos subjetivos de impaciência) .

$$
\text { SIM ? NÃO ? }
$$

xi. Tem dificuldade em brincar ou participar de atividades recreativas tranqüilamente

$$
\text { SIM ? NÃO ? }
$$

xii. Está sempre em movimento, ou age como de "estivesse ligado na tomada"

$$
\text { SIM ? NÃO ? }
$$


xiii. Fala excessivamente

$$
\text { SIM ? NÃO ? }
$$

IMPULSIVIDADE:

xiv. Começa a responder a perguntas q. ainda não foram completadas

$$
\text { SIM ? NÃO ? }
$$

xv. Tem dificuldade em esperar sua vez em jogos ou situações em grupo

$$
\text { SIM ? NÃO ? }
$$

xvi. Interrompe ou se intromete nas atividae dos outros (p. ex. invade conversas ou jogos)

$$
\text { SIM ? NÃO ? }
$$

\section{Critérios Adicionais:}

2. Alguns sintomas de hiperatividade - impulsividade ou inatenção que causaram comprometimento estavam presentes antes dos 7 anos de idade.

$$
\text { SIM ? NÃO ? }
$$

3. Algum comprometimento pelos sintomas está presente em 2 ou + ambientes (p. ex. escola ou trabalho e no lar)

$$
\text { SIM ? NÃO ? }
$$

4. Deve haver evidências claras de comprometimento clinicamente significativo da função social, acadêmica ou ocupacional. Há?

$$
\text { SIM ? NÃO ? }
$$

5. Os sintomas não ocorrem exclusivamente durante o curso do distúrbio difuso do desenvolvimento, esquizofrenia ou outro distúrbio psicótico, e não são mais bem explicados por outra afecção mental (por ex. distúrbio de humor, dist. de ansiedade, dist. dissociativo ou dist. da personalidade)

OCORREM ?

NÃO OCORREM ?

4)Antecedentes:
4.1)NN: Pré-Natal
( ) $\operatorname{Sim}$ ( ) Não
Sangramentos
( ) Sim ( ) Não
Febre/Exantemas
( ) Sim ( ) Não
Hipert. Arterial
( ) Sim ( ) Não
$\begin{array}{llll}\text { Uso de medicação e/ou Drogas de Abuso ( ) } \operatorname{Sim} & \text { ( ) Não } \\ \text { Trauma } & \text { ( ) Sim } \operatorname{Sim} & \text { ( ) Não }\end{array}$
( ) Sim ( ) Não
Parto ( ) NL ( )Fórceps ( ) Cesárea
( ) Hospitalar ( ) Domiciliar

$\begin{array}{lll}\text { À Termo } & \text { ( ) Sim } & \text { ( ) Não } \\ \text { Chorou logo ao nascer } & \text { ( ) Sim } & \text { ( ) Não } \\ \text { Cianose } & \text { ( ) Sim } & \text { ( ) Não }\end{array}$
PN: $\quad P C$ :
Est.: $\quad$ APGAR:
Icterícia Patológica ( ) Sim ( ) Não
Alta com dias de vida.

4. 2) Pessoais:

Internações

Se sim, descreva:
Cirurgias
Se sim, descreva:
( ) Sim ( ) Não
Doenças próprias da Infância
( ) Sim ( ) Não
Se sim, descreva:
Uso Contínuo de Medicação
( ) Sim ( ) Não
Se sim, descreva:
TCE com alteração da consciência
( ) Sim ( ) Não 
Convulsão Febril

Epilepsia

Outros:

4.3)Familiares

Mãe:

Pai:

Irmãos:

Doenças na família

Casos semelhantes na família

5)DNPM:

$$
\text { Marco Idade }
$$

Sustento cefálico:

Sentou com apoio:

Sentou sem apoio:

Engatinhou:

Em pé com apoio:

Em pé sem apoio:

Andou sem apoio:

Controle esfincteriano: vesical diurno

Anal diurno

$1^{\circ}$ as Palavras:

Atualmente fala

Dislalias

Gagueira

Escolaridade:

Atualmente cursa série

\section{Repetência}

Professor tem queixas

Quais?

6)Sono:

Dorme/Sonolência durante o dia ( ) Sim ( ) Não

Deita durante o dia às

( ) Normal

( ) Sim

( ) Sim

( ) Sim ( ) Não

( ) $\operatorname{Sim}($ ) Não
( ) $\operatorname{Sim}$ ( ) Não

Deita-se durante a noite às hs e levanta-se às hs e levanta-se às hs.

Urina quando está dormindo à noite

Urina quando está dormindo durante o dia

Fala quando está dormindo

( ) Sim ( ) Não

( ) Sim ( ) Não

vesical noturno anal noturno

( ) Anormal

( ) Não

( ) Não

( )

$\operatorname{sim}($ ) Não

( ) $\operatorname{Sim}($ ) Não

( ) $\operatorname{Sim}($ ) Não

Range os dentes quando está dormindo

Senta-se na cama ou anda quando está dormindo

Grita sem motivo quando está dormindo

Conta que tem sonhos ruins o que dão medo

Tem sono restaurador

Ronca mais da metade do tempo do sono

Dorme de boca aberta

( ) Sim ( ) Não

Já foi ao médico por problemas de sono

( ) Sim ( ) Não

( ) Sim ( ) Não

( ) $\operatorname{Sim}$ ( ) Não

( ) $\operatorname{sim}($ ) Não

( ) Sim ( ) Não

( ) $\operatorname{Sim}$ ( ) Não

7)Comportamento:

Roe unhas

( ) $\operatorname{Sim}$ ( ) Não

Tem companheiros

( ) $\operatorname{Sim}($ ) Não

( ) $\operatorname{Sim}$ ( ) Não

Da mesma idade ( ) Sim ( ) Não

Do mesmo Sexo ( ) Sim ( ) Não

Faz amizades com facilidade

( ) Sim ( ) Não

É Carinhoso

( ) $\operatorname{Sim}($ ) Não

É agressivo

( ) $\operatorname{Sim}$ ( ) Não

8) Vacinas estão em dia

( ) Sim ( ) Não 


\title{
Anexo 8 - Manual explicativo grupo controle
}

\author{
Projetos de Pesquisa - TDAH \\ Mestrado - Instituto da Criança / Faculdade de Medicina / Setor: Pediatria
}

Perfil psicomotor de crianças com transtorno de déficit de atenção/hiperatividade

O Instituto da Criança do Hospital das Clinicas da Faculdade de Medicina da Universidade de São Paulo (HCFMUSP) iniciou algumas pesquisas com crianças com transtorno de déficit de atenção / hiperatividade, transtorno muito comum na infância no qual a criança apresenta sinais de desatenção, hiperatividade e/ou impulsividade.

Trata-se de um transtorno que prejudica intensamente as crianças acometidas, assim como os seus familiares e o ambiente onde vivem.

Os sintomas interferem com o funcionamento em pelo menos dois de três contextos: em casa, na escola, e/ou em contextos sociais. Estas crianças podem apresentar atrasos no desenvolvimento neuropsicomotor.

Em parceria com escolas do ensino regular, estamos desenvolvendo a triagem de pacientes com TDAH e também entrevistas com crianças sem o transtorno, para que haja possibilidades de melhor qualidade da pesquisa, já que é necessária a comparação com as crianças sem os sintomas de TDAH.

Mas para que seja realizada é muito importante a sua participação para levantamento destes dados, pois há a necessidade de comparação das respostas dos pacientes e seus responsáveis com a de crianças que não apresentem nenhum distúrbio físico e neuropsiquiátrico, para que possamos observar se há prejuízo na qualidade de vida das crianças com TDAH. Por este motivo a importância de sua participação e de seu filho.

O grupo de estudo será composto pelas crianças acompanhadas no Ambulatório de Distúrbios de Aprendizado do Instituto da Criança do HCFMUSP, com diagnóstico de TDAH do tipo combinado e idade entre sete e onze anos.

O grupo de crianças sem o transtorno será composto por crianças que apresentem as mesmas características do grupo de estudo (idade, sexo, nível sócio-econômico) e não apresentem nenhum distúrbio psiquiátrico e/ou doença neurológica associada.

A pasta que o(a) $\operatorname{sr}(a)$. está recebendo possui esse informativo, para que saiba a importância deste estudo e da comparação com crianças sem o transtorno, no caso o seu filho(a). Em todas as pesquisas que o Hospital das Clínicas desenvolve é necessário o consentimento do pai/mãe e/ou cuidador da criança por meio da assinatura dos termos de consentimento livre e esclarecido que está anexo nesta pasta. Além dos termos de consentimento, também há um breve questionário que se chama SNAP-IV, utilizado para triagem de crianças com o TDAH, solicitamos que responda para que possamos comparar com as crianças com TDAH que os pais responderam a mesma avaliação.

Ressaltamos que esta pesquisa foi apresentada a Escola Estadual Keizo Ishihara (ou Escola Estadual Eduardo Carlos Pereira), que está de acordo com a proposta do estudo, até mesmo pela importância que este estudo apresenta. Todas as avaliações serão realizadas na própria escola, não ocorrendo nenhum transtorno em relação à locomoção ou horários que não sejam o de aula do próprio aluno, enfatizamos que o estudo é composto pela Escala de Desenvolvimento Motor, que avalia através de testes simples a coordenação, o equilíbrio, a noção de corpo, espaço e tempo.

Solicitamos sua colaboração na realização deste trabalho.

Estamos à disposição para demais dúvidas que possam surgir. 


\title{
Anexo 9 - Escala de Desenvolvimento Motor
}

\author{
Motricidade Fina \\ 2 ANOS - CONSTRUÇÃO DE UMA TORRE - Material: 12 cubos em desordem; tomam-se 4 \\ e com eles se monta uma torre diante da criança. A criança deve fazer uma torre de quatro \\ cubos ou mais.
}

3 ANOS - CONSTRUÇÃO DE UMA PONTE - Material: 12 cubos em desordem; tomam-se 3 e com eles se constrói uma ponte diante da criança. Podem-se ensinar várias vezes a forma de fazê-lo. É suficiente que a ponte se mantenha ainda que não esteja muito bem equilibrado.

4 ANOS - ENFIAR A LINHA NA AGULHA - Material: Linha número 60 e agulha de costura $(1 \mathrm{~cm} . \times 1 \mathrm{mlm})$. Para começar, mãos separadas $10 \mathrm{~cm}$. A linha passa aos dedos em $2 \mathrm{~cm}$. Comprimento total da linha, $15 \mathrm{~cm}$., figura nQ3. Duração: 9 segundos. Ensaios: dois.

5 ANOS - FAZER UM NÓ - Material: Um par de cordões de sapatos de $45 \mathrm{~cm}$., e um lápis. Fazer um nó simples num lápis. Se aceita qualquer tipo de nó desde que este não se desmanche.

6 ANOS - LABIRINTO - Criança sentada numa mesa escolar diante de um lápis e uma folha contendo os labirintos. Traçar com um lápis uma linha contínua desde a entrada até a saída do primeiro labirinto e imediatamente iniciar o segundo. Após 30 segundos de repouso, começar o mesmo exercício com a mão esquerda.

Erros: A linha ultrapassa o labirinto mais de duas vezes com a mão dominante, e mais de três vezes com a mão não dominante; tempo limite ultrapassado; levantar mais que uma vez o lápis do papel. Duração: 1 minuto e 20 segundos para a mão dominante (direita ou esquerda) e 1 minuto 25 segundos para a mão não dominante (direita ou esquerda). № de tentativas: duas $\mathrm{p} /$ cada mão.

7 ANOS - BOLINHAS DE PAPEL - Fazer uma bolinha compacta com um pedaço de papel de seda $(5 \times 5 \mathrm{~cm}$.) com uma só mão, palma para baixo e sem ajuda da outra mão. Após 15 segundos de repouso, o mesmo exercício com a outra mão. Erros: Tempo limite ultrapassado; bolinha pouco compacta. Duração: 15 segundos para a mão dominante e 20 segundos para a mão não dominante. Tentativas: duas para cada mão. Observar se há sincinesias (movimentos involuntários).

8 ANOS - PONTA DO POLEGAR - Com a ponta do polegar, tocar com a máxima velocidade possível os dedos da mão, um após o outro, sem repetir a seqüência. Inicia-se do dedo menor para o polegar, retomando para o menor.

O mesmo exercício com a outra mão. Erros: Tocar varias vezes o mesmo dedo; tocar dois dedos ao mesmo tempo; esquecer de um dedo; tempo ultrapassado. Duração: cinco segundos. Tentativas: duas para cada mão.

9 ANOS - LANÇAMENTO COM UMA BOLA - Arremessar uma bola (seis cm de diâmetro), num alvo de $25 \times 25$, situado na altura do peito, $1,50 \mathrm{~m}$ de distância (lançamento a partir do braço flexionado, mão próxima do ombro, pés juntos). Erros: deslocamento exagerado do braço; cotovelo não ficou fixo ao corpo durante o arremesso; acertar menos de duas vezes sobre três com a mão dominante e um sobre três com a mão não dominante. Tentativas: três para cada mão.

10 ANOS - CÍRCULO COM O POLEGAR - A ponta do polegar esquerdo sobre a ponta do índice direito e vice-versa. $O$ índice direito deixa a ponta do polegar esquerdo e desenhando uma circunferência ao redor do índice esquerdo e vai buscar a ponta do polegar esquerdo, entretanto permanece o contato do índice esquerdo com o polegar direito. A continuação do índice esquerdo que se faz à manobra, e assim sucessivamente, com a maior velocidade possível. Em torno de 10 segundos a criança fecha os olhos e continua assim por espaço de outros 10 segundos. Erros: movimento mal executado; menos de 10 círculos, não execução com os olhos fechados, figura 8. Tentativas: três.

11 ANOS - AGARRAR UMA BOLA - Agarrar com uma mão uma bola (6 cm de diâmetro), lançada desde de 3 metros de distância. A criança deve manter o braço relaxado ao longo do corpo até que se diga "agarre". Após 30 segundos de repouso, o mesmo exercício com a outra mão. Erros: agarrar menos de três vezes sobre cinco, com a dominante; menos de duas vezes sobre cinco com a mão não dominante. Tentativas: cinco para cada mão. 


\section{Motricidade Global}

2 ANOS - SUBIR SOBRE UM BANCO - Subir, com apoio, em um banco de $15 \mathrm{~cm}$ de altura e descer.(Banco situado ao lado de uma parede).

3 ANOS - SALTAR SOBRE UMA CORDA - Com os pés juntos: saltar por cima de uma corda estendida sobre o solo (sem impulso, pernas flexionadas). Erros: pés separados; perder o equilíbrio e cair. Tentativas: três (duas tentativas deverão ser positivas).

4 ANOS - SALTAR SOBRE O MESMO LUGAR - Dar saltos, sete ou oito sucessivamente, sobre o mesmo lugar com as pernas ligeiramente flexionadas. Erros: movimentos não simultâneos de ambas as pernas, cair sobre os calcanhares. Tentativas: duas.

5 ANOS - SALTAR UMA ALTURA DE $20 \mathrm{CM}$ - Com os pés juntos: saltar sem impulso uma altura de $20 \mathrm{~cm}$. Material: dois suportes com uma fita elástica fixada nas extremidades dos mesmos, altura: 20 em. Erros: tocar no elástico; cair (apesar de não ter tocado no elástico); tocar no chão com as mãos. Tentativas: três, sendo que duas deverão ser positivas.

6 ANOS - CAMINHAR EM LINHA RETA - Com os olhos abertos, percorrer 2 metros em linha reta, posicionando alternadamente o calcanhar de um pé contra a ponta do outro. Erros: se afastar da linha; balanceios; afastar um pé do outro; execução ruim. Tentativas: três.

7 ANOS - PÉ MANCO - Com os olhos abertos, saltar ao longo de uma distância de 5 metros com a perna esquerda, à direita flexionada em ângulo reto com o joelho, os braços relaxados ao longo do corpo. Após um descanso de 30 segundos, o mesmo exercício com a outra perna. Erros: distanciar-se mais de $50 \mathrm{~cm}$. da linha; tocar no chão com a outra perna; balançar os braços. Tentativas: duas para cada perna. Tempo indeterminado.

8 ANOS - SALTAR UMA ALTURA DE $40 \mathrm{CM}$ - Com os pés juntos: saltar sem impulso uma altura de $40 \mathrm{~cm}$, figura nQ16. Material: dois suportes com uma fita elástica fixada nas extremidades dos mesmos, altura: $40 \mathrm{~cm}$. Erros: tocar no elástico; cair (apesar de não ter tocado no elástico); tocar no chão com as mãos. Tentativas: três no total, sendo que duas deverão ser positivas.

9 ANOS - SALTAR SOBRE O AR - Salto no ar, flexionar os joelhos para tocar os calcanhares com as mãos, figura nQ17. Erros: não tocar nos calcanhares. Tentativas: três.

10 ANOS - PÉ MANCO COM UMA CAIXA DE FÓSFOROS - Joelho flexionado em ângulo reto, braços relaxados ao longo do corpo. A $25 \mathrm{~cm}$. do pé que repousa no solo se coloca uma caixa de -fósforos. A criança deve levá-la impulsionando-a com o pé até o ponto situado a 5 metros. Erros: tocar no chão (ainda que uma só vez) com o outro pé; movimentos exagerados com os braços, a caixa ultrapassar em mais de $50 \mathrm{~cm}$ do ponto fixado; falhar no deslocamento da caixa. Tentativas: três.

11 ANOS - SALTAR SOBRE UMA CADEIRA - Saltar sobre uma cadeira de 45 a $50 \mathrm{~cm}$ com uma distancia de 50 centímetros da mesma. $O$ encosto será sustentado pelo examinador. Erros: perder o equilíbrio e cair, agarrar-se no encosto da cadeira. Tentativas: três.

\section{Equilíbrio}

2 ANOS - EQUILÍBRIO ESTÁTICO SOBRE UM BANCO - Sobre um banco de $15 \mathrm{~cm}$. de altura, deve a criança manter-se imóvel, pés juntos, braços relaxados ao longo do corpo, figura nQ18. Erros: deslocar os pés, mover os braços. Duração: 10 segundos.

3 ANOS - EQUILÍBRIO SOBRE UM JOELHO - Braços ao longo do corpo, pés juntos, apoiar um joelho no chão sem mover os braços ou o outro pé. Manter esta posição, com o tronco ereto (sem sentar-se sobre o calcanhar), figura nQ19. Após 20 segundos de descanso, o mesmo exercício com a outra perna. Erros: tempo inferior a 10 segundos; deslizamentos dos braços, do pé ou joelho; sentar-se sobre o calcanhar. Tentativas: duas para cada perna. 4 ANOS - EQUILÍBRIO COM O TRONCO FLEXIONADO - Com os olhos abertos, pés juntos, mãos apoiadas nas costas: flexionar o tronco em ângulo reto e manter esta posição. Erros: mover os pés; flexionar as pernas; tempo inferior a 10 segundos. Tentativas: duas.

5 ANOS - EQUILíBRIO NAS PONTAS DOS PÉS - Manter-se sobre a ponta dos pés, olhos abertos, braços ao longo do corpo, pés e pernas juntos. Duração: 10 segundos. Tentativas: três.

6 ANOS - PÉ MANCO ESTÁTICO - Com os olhos abertos, manter-se sobre a perna direita, a outra permanecerá flexionada em ângulo reto, coxa paralela à direita e ligeiramente em abdução, braços ao longo do corpo. Fazer um descanso de 30 segundos, o mesmo exercício com a outra perna. Erros: baixar mais de três vezes a perna levantada; tocar com 
o outro pé no chão; saltar; elevar-se sobre a ponta do pé; balanceias. Duração: 10 segundos. Tentativas: três.

7 ANOS - EQUILÍBRIO EM CÓCORAS - Em cócoras, braços estendidos lateralmente, olhos fechados, calcanhares e pés juntos. Erros: cair; sentar-se sobre os calcanhares; tocar no chão com as mãos; deslizar-se; baixar os braços três vezes. Duração: 10 segundos. Tentativas: três.

8 ANOS - EQUILÍBRIO COM O TRONCO FLEXIONADO - Com os olhos abertos, mãos nas costas, elevar-se sobre as pontas dos pés e flexionar o tronco em ângulo reto (pernas retas). Erros: flexionar as pernas mais de duas vezes; mover-se do lugar; tocar o chão com os calcanhares. Duração: 10 segundos. Tentativas: duas.

9 ANOS - FAZER UM QUATRO - Manter-se sobre o pé esquerdo, a planta do pé direito apoiada na face interna do joelho esquerdo, mãos fixadas nas coxas, olhos abertos. Após um descanso de 30 segundos, executar o mesmo movimento com a outra perna. Erros: deixar cair uma perna; perder o equilíbrio; elevar-se sobre a ponta dos pés. Duração: 15 segundos. Tentativas: duas para cada perna.

10 ANOS - EQUILÍBRIO NA PONTA DOS PÉS - OLHOS FECHADOS - Manter-se sobre a ponta dos pés, olhos fechados, braço ao longo do corpo, pés e pernas junta. Erros: moverse do lugar; tocar o chão com os calcanhares; balançar o corpo (se permite ligeira oscilação). Duração: 15 segundos. Tentativas: três.

11 ANOS - PÉ MANCO ESTÁTICO - OLHOS FECHADOS - Com os olhos fechados, manter-se sobre a perna direita, o joelho esquerdo flexionado em ângulo reto, coxa esquerda paralela à direita e em ligeira abdução, braços ao longo do corpo. Após 30 segundos de descanso, repetir o mesmo exercício com a outra perna. Erros: baixar mais de três vezes a perna; tocar o chão com a perna levantada; mover-se do lugar; saltar. Duração: 10 segundos. Tentativas: duas para cada perna.

\section{Esquema Corporal}

CONTROLE DO PRÓPRIO CORPO (2 A 5 ANOS)

- PROVA DE IMITAÇÃO DOS GESTOS SIMPLES (movimentos das mãos)

A criança, de pé diante do examinador, imitará os movimentos de mãos e braços que realiza este; o qual está sentado e próximo a criança, para poder por suas mãos em posição neutra entre cada um destes gestos.

Item 1: o examinador apresenta suas mãos abertas, palmas para face do sujeito $(40 \mathrm{~cm}$ de distância entre as mãos, a $20 \mathrm{~cm}$ do peito).

Item 2: o mesmo, com os punhos fechados.

Item 3: Mão esquerda aberta, mão direita fechada.

Item 4: Posição inversa ao anterior.

Item 5: Mão esquerda vertical, mão direita horizontal, tocando a mão esquerda em ângulo reto.

Item 6: Posição inversa.

Item 7: Mão esquerda plana, polegar em nível do estemo, mão e braços direitos inclinados, distância de 30 em. entre as mãos, mão direita por cima da mão esquerda.

Item 8: Posição inversa.

Item 9: As mãos estão paralelas, a mão esquerda está diante da mão direita a uma distância de 20 em., a mão esquerda está por cima da direita, desviada uns $10 \mathrm{em}$. Previamente se pede a criança que feche os olhos; a profundidade pode deduzir-se do movimento das mãos do examinador.

Item 10: Posição inversa.

2aㅗ Prova de imitação de gestos simples: movimentos dos braços

Item 11: O examinador estende o braço esquerdo, horizontalmente para a esquerda, com a mão aberta.

Item 12: O mesmo movimento, porém com o braço direito, para a direita.

Item 13: Levantar o braço esquerdo.

Item 14: Levantar o braço direito.

Item 15: Levantar o braço esquerdo e estender o direito para a direita.

Item 16: Posição inversa.

Item 17: Estender o braço esquerdo para diante e levantar o direito. 
Item 18: Posição inversa.

Item 19: Com os braços estendidos obliquamente, mão esquerda no alto, mão direita abaixo, com o tronco erguido.

Item 20: Posição inversa.

Pontuação

IDADE MOTORA

PONTOS

3 ANOS

$7-12$ acertos

4 ANOS

$13-16$ acertos

5 ANOS

$17-20$ acertos

PROVA DE RAPIDEZ (6 a 11 ANOS)

Material: folha de papel quadriculado com $25 \times 18$ quadrados (quadro de um em. de lado), lápis preto $\mathrm{n}^{\circ} 2$ e cronômetro. A 'folha quadriculada se apresenta em sentido longitudinal. A criança toma o lápis com a mão que preferir (mão dominante).

Iniciar o mais rápido que puder até completar o tempo da prova. Estimular várias vezes: "Mais rápido". Tempo: 1 minuto.

Critérios da prova:

- Caso os traços forem lentos e precisos ou em forma de desenhos geométricos, repetir uma vez mais a prova, mostrando claramente os critérios;

- Observar durante a prova se o examinando apresenta dificuldades na coordenação motora, instabilidade, ansiedade, e sincinesias.

\section{Organização Espacial}

2 ANOS - TABULEIRO / POSIÇÃO NORMAL - Apresenta-se o tabuleiro a criança, com a base do triângulo frente a ela. Tiram-se as peças posicionando-as na frente de suas respectivas perfurações. "Agora coloque você as peças nos buracos". Tentativas: duas.

3 ANOS - TABULEIRO I POSiÇÃO INVERTIDA - O mesmo material utilizado anteriormente, porém, deverá retirar as peças e deixá-las alinhadas com o vértice do triângulo posicionado para a criança. Dá uma volta no tabuleiro. Sem limite de tempo. Tentativas: duas.

4 ANOS - PROVA DOS PALITOS - Dois palitos de diferentes comprimentos: cinco e seis centímetros. Colocar os palitos sobre a mesa. Os mesmos estarão paralelos e separados por 2,5 cm. "Qual o palito mais longo? Colocar o dedo em cima do palito mais longo". Três provas trocando de posição os palitos. Se falhar em uma das três tentativas, fazer três mais trocando as posições dos palitos. Resultado positivo quando a criança acerta três de três tentativas ou cinco de seis tentativas.

5 ANOS - JOGO DE PACIÊNCIA - Colocar um retângulo de cartolina de $14 \times 10 \mathrm{~cm}$. e em sentido longitudinal, diante da criança. Ao seu lado e um pouco mais próximo do sujeito, as duas metades do outro retângulo, cortado pela diagonal, com as hipotenusas para o exterior e separadas uns centímetros. "Pegue estes triângulos e junte-os de maneira que saia algo parecido a este retângulo", Tentativas: três em 1 minuto. NQ tentativas: duas, sendo que cada tentativa não deverá ultrapassar um minuto.

6 ANOS - DIREITA I ESQUERDA - CONHECIMENTO SOBRE SI - Identificar em si mesmo a noção de direita e esquerda.

1. Levantar a mão direita

2. Levantar a mão esquerda

3. Indicar o olho direito

O examinador não executará nenhum movimento, apenas o examinando. Total de três perguntas e todas deverão ser respondidas corretamente. Ex.: "Mostre-me sua mão direita". Êxito: Três acertos - $3 / 3$.

7 ANOS - EXECUÇÃO DE MOVIMENTOS EXECUÇÃO DE MOVIMENTOS NA ORDEM - O examinador solicitará ao examinando que realize movimentos, de acordo com a seqüência abaixo. Ex.: "Agora você irá colocar a mão direita na orelha esquerda". Êxito: Cinco acertos $-5 / 6$.

8 ANOS - DIREITA / ESQUERDA - RECONHECIMENTO SOBRE OUTRO - O examinador se colocará de frente ao examinando e perguntará: "agora você irá identificar minha mão direita". 
1. Toca-me a mão direita

2. Toca-me a mão esquerda

3. Em que mão tem a bola?

9 ANOS - REPRODUÇÃO DE MOVIMENTOS - REPRESENTAÇÃO HUMANA - Frente a frente, o examinador irá executar alguns movimentos e o examinando irá prestar muita atenção nos movimentos das mãos.

"Eu vou fazer certos movimentos que consistem em levar uma mão (direita ou esquerda) até um olho ou uma orelha (direita ou esquerda), desta maneira" (demonstração rápida). "Você fixará no que estou fazendo e irá fazer o mesmo, não poderá realizar movimentos de espelho". Se a criança entendeu o teste, através dos primeiros movimentos, se pode prosseguir, caso contrário, oferece uma segunda explicação. Êxitos: Seis acertos - 6/8.

10 ANOS - REPRODUÇÃO DE MOVIMENTOS - FIGURA HUMANA - Frente a frente, o examinador irá mostrar algumas figuras' esquematizadas e o examinando irá prestar muita atenção nos desenhos e irá reproduzi-los. Os mesmos movimentos executados anteriormente (prova de 9 anos). "Você fará os mesmos gestos e com a mesma mão do boneco esquematizado". Éxitos: Seis acertos - 6/8.

11 ANOS - RECONHECIMENTO DA POSIÇÃO RELATIVA DE TRÊS OBJETOS Sentados, frente a frente, examinador fará algumas perguntas para o examinando que permanecerá com os braços cruzados. Material: três cubos ligeiramente separados (15 em.) colocados da esquerda para a direita sobre a mesa, como segue: AZUL, AMARELO, VERMELHO. "Você vê os três ob etos (cubos) que estão aqui na sua frente. Você irá responder rapidamente as perguntas que irei fazer". O examinando terá como orientação espacial (ponto de referência) o examinador.

\section{Organização Temporal}

LINGUAGEM

2 ANOS - Frase de duas palavras, observação da linguagem espontânea. A prova se considera bem resolvida se a criança é capaz de expressar-se de outra forma do que com palavras isoladas, quer dizer, se sabe unir ao menos duas palavras; por exemplo: "Mamãe não está", "está fora", se consideram êxitos. Pelo contrário, "NENÉM BOBO", não tem valor. Êxitos: basta um só êxito. Se da por bem resolvida a prova quando consegue repetir ao menos uma das frases sem erro, para as frases de três, quatro, cinco anos.

3 ANOS - Repetir uma frase de seis a sete sílabas: "Você sabe dizer mamãe?" Diz agora: "GA TINHO PEQUENO". Fazer repetir então: A) "EU TENHO UM CACHORRINHO PEQUENO" B) "O CACHORRO PEGA O GA TO" C) "NO VERÃO FAZ CALOR".

4 ANOS - Recorrendo as frases: "Você vai repetir": A) "VAMOS COMPRAR PASTÉIS PARA MAMÃE" B) "O JOÃO GOSTA DE JOGAR BOLA". Se a criança vacilar, animá-la a provar outra vez dizendo-lhe: "vamos, diz". A frase não pode ser repetida.

5 ANOS - Lembrando as frases: "Bom, vamos continuar, você vai repetir" . A) "JOÃO VAI FAZER UM CASTELO DE AREIA" B) "LUIS SE DIVERTE JOGANDO FUTEBOL COM SEU IRMÃO"

\section{ESTRUTURA ESPAÇO-TEMPORAL (6 a 11 ANOS)}

REPRODUÇÃO POR MEIO DE GOLPES - ESTRUTURAS TEMPORAIS

Examinador e criança sentados frente a frente, com um lápis na mão cada um. "Você irá escutar diferentes sons, e com o lápis irá repeti-los. Escute com atenção".

- $\quad$ Tempo curto: em torno de 1/4 de segundo (00), dado com o lápis sobre a mesa.

- $\quad$ Tempo longo: em torno de 1 segundo $\left(\begin{array}{lll}0 & 0 & 0\end{array}\right)$, dado com o lápis sobre a mesa.

O examinador dará golpes da primeira estrutura da prova e a criança repetirá os mesmos. O examinador golpeia outras estruturas e a criança continua repetindo. Em quanto os tempos curtos e longos são reproduzidos corretamente se passa já diretamente a prova. Os movimentos (golpes com um lápis) não poderão ser vistos pelo examinando. Ensaios: Se a criança falha, nova demonstração e novo ensaio. Parar definitivamente quando a criança cometer três erros consecutivos. Estes períodos de tempo são difíceis de apreciar; já que importa realmente é que a sucessão seja correta.

SIMBOLIZAÇÃO (DESENHO) DE ESTRUTURAS ESPACIAIS

As estruturas espaciais podem ser representadas com círculos (diâmetro de três $\mathrm{cm}$ ) colados em um cartão. "Agora você irá desenhar umas esferas, aqui você tem um papel e 
um lápis, de acordo com as figuras que irei mostrar". Apresenta-se então a primeira estrutura de ensaio, dando-lhe uma explicação se for necessário. "Muito bem, vejo que você entendeu. Agora você irá prestar bem a atenção nas figuras que irei mostrar e as desenhará o mais rápido possível neste papel". A criança quase sempre e espontaneamente desenha já um círculo. Tentativa: parar a prova se a criança falhar duas estruturas sucessivas.

SIMBOLIZAÇÃO DE ESTRUTURAS TEMPORAIS

a) LEITURA - REPRODUÇÃO POR MEIO DE GOLPES

As estruturas simbolizadas serão representadas exatamente da mesma maneira que as estruturas espaciais (círculos colados sobre o cartão). "Vamos fazer algo melhor. Apresenta outra vez os círculos no cartão e em vez da criança desenhá-los, ela dará pequenos golpes com o lápis". Parar se a mesma falhar duas estruturas sucessivas.

b) TRANSCRIÇÃO DE ESTRUTURAS TEMPORAIS - DITADO - "Para finalizar as provas, serei eu quem dará os golpes com o lápis e você irá desenhá-los. Parar após dois erros sucessivos".

RESULTADOS

Entendemos por êxitos as reproduções e transcrições claramente estruturadas. Concedemos um ponto por um golpe ou desenho bem resolvido e totalizamos os pontos obtidos nos diversos aspectos da prova.

Pontuação

IDADE MOTORA

6 ANOS

7 ANOS

8 ANOS

9 ANOS

PONTOS

6-13 acertos

14 - 18 acertos

19 - 23 acertos

10 ANOS

24-26 acertos

11 ANOS

27-31 acertos

32-40 acertos 


\section{Anexo 10 - Distribuição grupo caso}

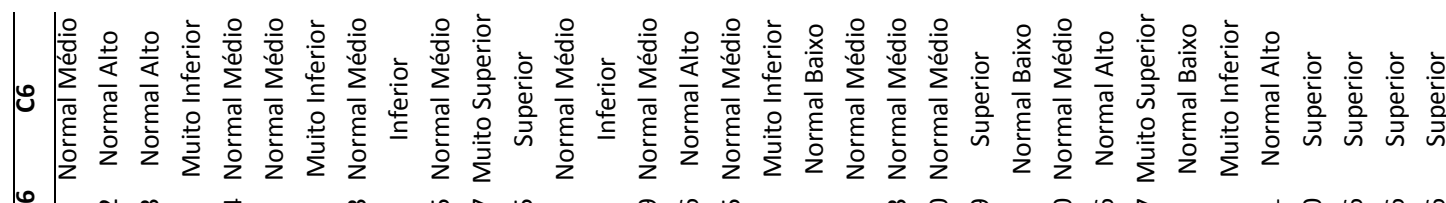

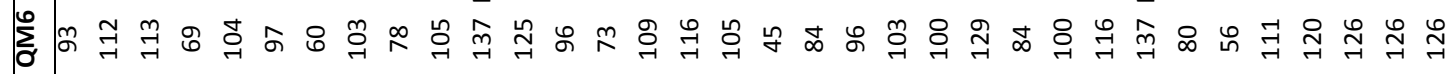

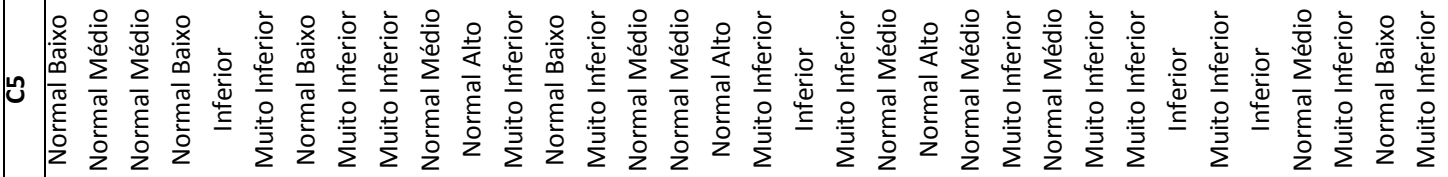

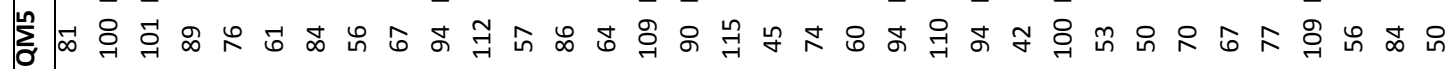
嵩

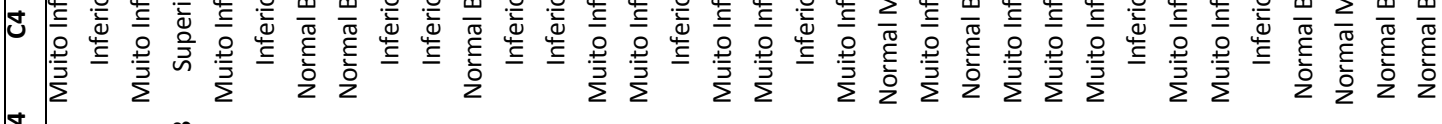
斿们

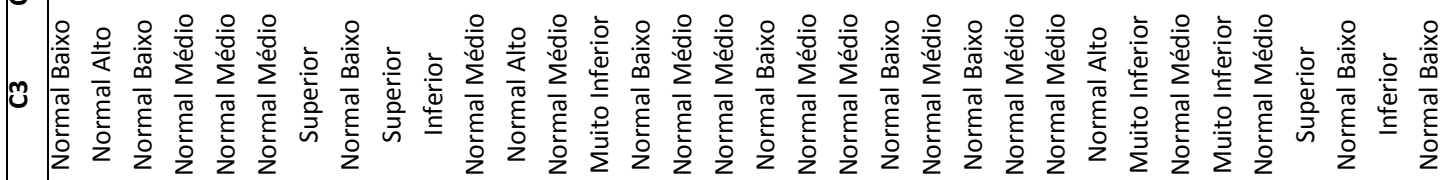
傢

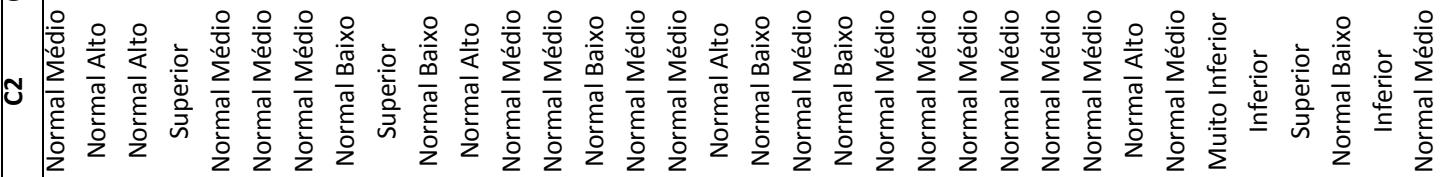

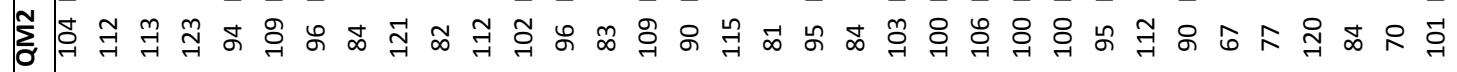

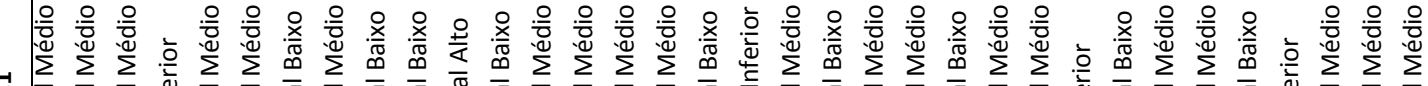

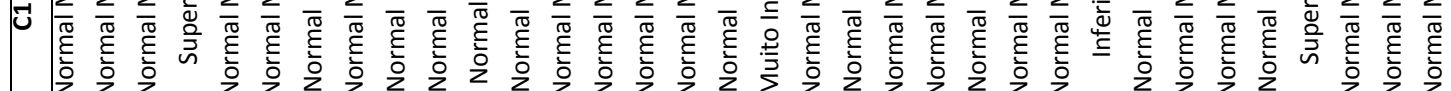

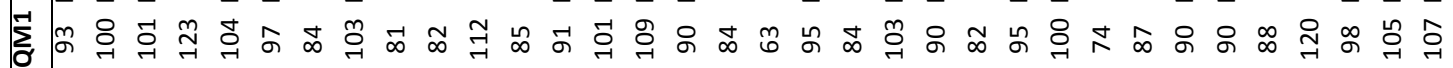

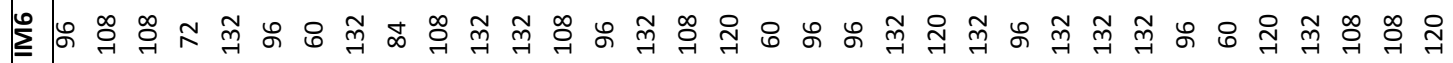
虽

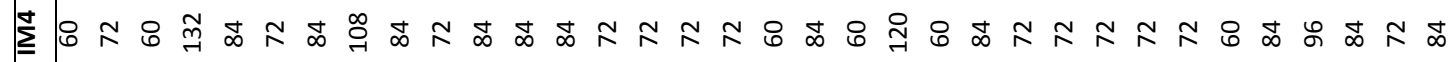
监

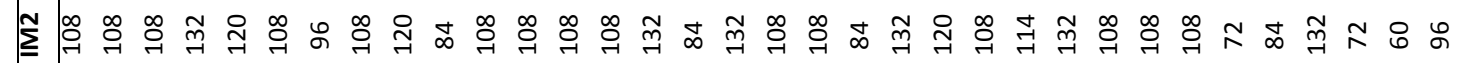
霍

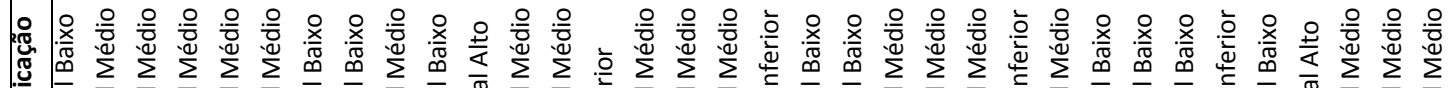

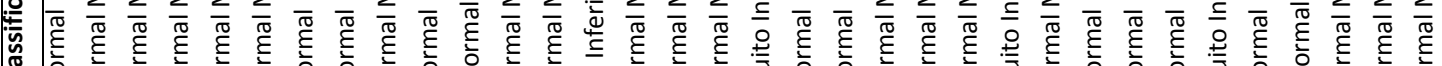

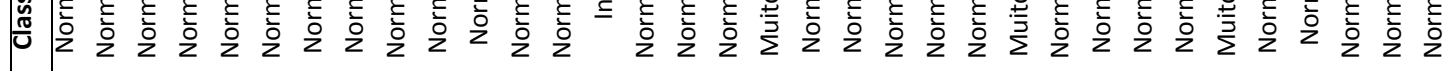

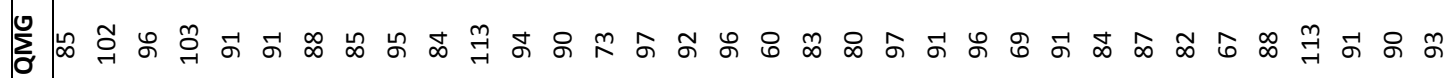
u品 我央 尊け 
Anexo 11 - Distribuição grupo controle

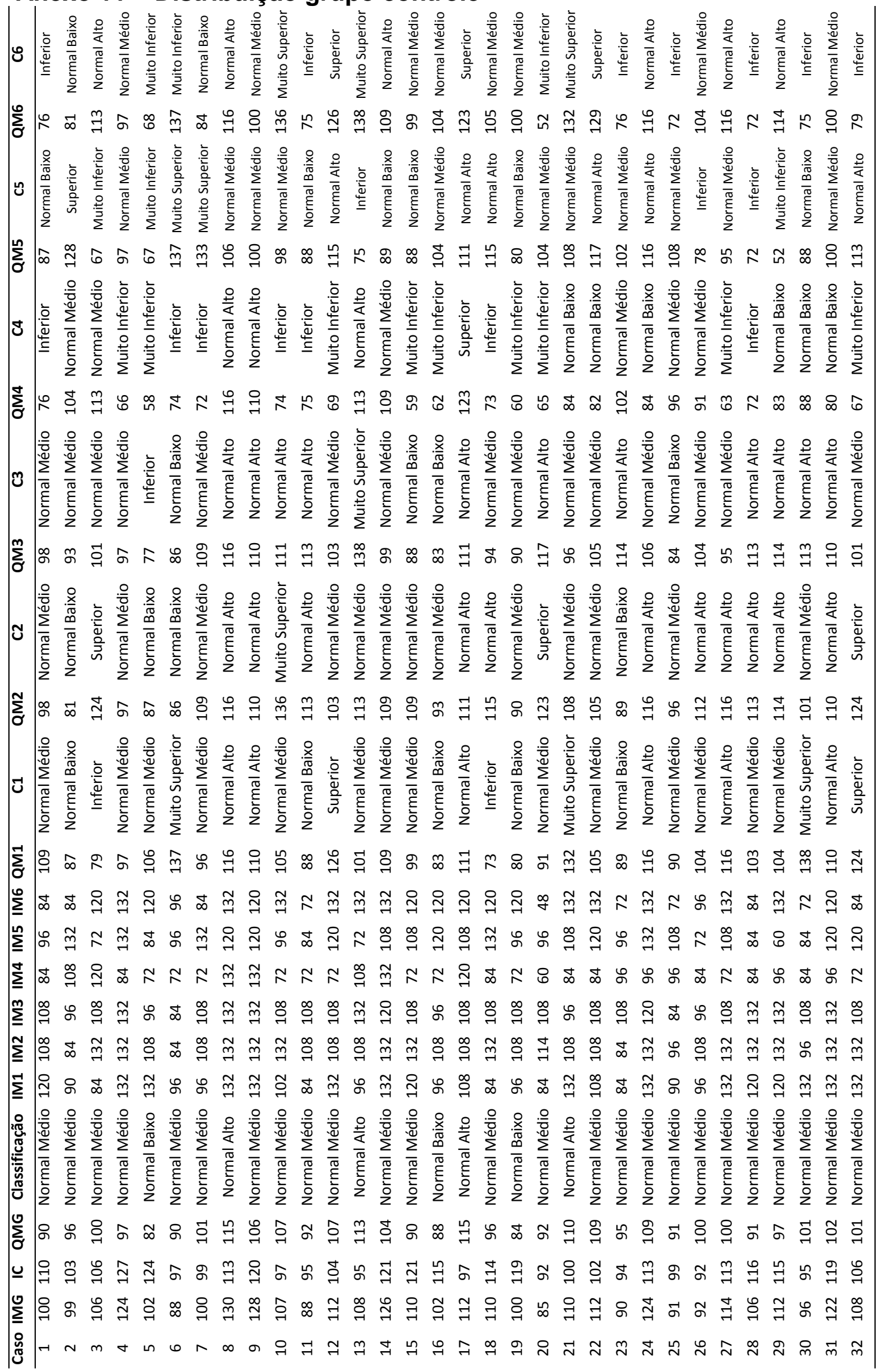




\section{REFERÊNCIAS BIBLIOGRÁFICAS}

1. Amaral $A H$, Guerreiro MM. Transtorno de déficit de atenção e hiperatividade: proposta de avaliação neuropsicológica para diagnóstico. Arq Neuropsiquiatr. 2001; 59 (4): 884-8.

2. Amaro KN, Santos APM, Brusamarelo S, Xavier R, Rosa Neto F. Validação das Baterias de Testes de Motricidade Global e Equilibrio da EDM. Rev Bras Ciência Mov. 2009; 17:1-17.

3. American Psychiatric Association. Diagnostic and Statistical Manual of Mental Disorders, Fourth edition, Text Revision. Washington (DC): American Psychiatric Association; 2000.

4. American Academy of Pediatrics. Subcommittee on AttentionDeficit/Hyperactivity Disorder and Committee on Quality Improvement. Clinical practice guideline: treatment of the schoolaged child with attention-deficit/hyperactivity disorder. Pediatrics. 2001; 108:1033-44.

5. Andersen SL. Trajectories of brain development: point of vulnerability or window of opportunity? Neurosci Biobehav Rev. 2003; 27(1-2):3-18.

6. Antony S, Ribeiro JP. A criança hiperativa: uma visão da Abordagem Gestálgica. Psicologia: Teoria e Pesquisa. 2004; 20 (2): 127-34. 
7. Araújo APQC. Avaliação e manejo da criança com dificuldade escolar e distúrbio de atenção. J Pediatr. 2002; 78 (Supl.1): S104-S110.

8. Araújo MM, Malloy-Diniz LF, Rocha FL. Impulsividade e acidentes de trânsito. Rev Psiq Clín. 2009; 36(2):60-8.

9. Arnsten AFT, Li BM. Neurobiology of Executive Functions: Catecholamine Influences on Prefrontal Cortical Functions. Biol Psychiatry. 2005; 57: 1377-84.

10.Ball SW, Gilman SE, Mick E, Fitzmaurice G, Ganz ML, Seidman LJ, Buka SL. Revisiting the association between maternal smoking during pregnancy and ADHD. J Psychiatric Research. 2010; 44:1058-62.

11. Barkley RA. International Consensus Statement on ADHD. J Am Acad Child Adolesc Psychiatry. 2002; 41 (12): 1389.

12. Barkley RA. Issues in the diagnosis of attention-deficit / hyperactivity disorder in children. Brain Dev. 2003; 25 (2): 77-83.

13. Berquin PC, Giedd JN, Jacobsen LK, Hamburger SD, Krain AL, Rapoport JL, Castellanos FX. Cerebellum in attention-deficit hyperactivity disorder: a morphometric MRI study. Neurology. 1998; $50(4): 1087-93$

14. Biederman J, Faraone SV. Attention-deficit hyperactivity disorder. Lancet. 2005; 366 (9481): 237-48. 
15. Bolfer C, Casella EB, Baldo MVC, Mota AM, Tsunemi MH, Pacheco SP, Reed UC. Reaction time assessment in children with ADHD. Arq Neuropsiquiatr. 2010;68(2):282-286.

16. Bugalho P, Correa B, Viana-Baptista M. Papel do cerebelo nas funções cognitivas e comportamentais: bases científicas e modelos de estudo. Acta Med Port. 2006; 19: 257-268.

17. Bush G, Frazier JA, Rauch SL, Seidman LJ, Whalen PJ, Jenike MA, Rosen BR, Biederman J. Anterior cingulate cortex dysfunction in attention deficit/hyperactivity disorder revealed by $\mathrm{fMRI}$ and the counting stroop. Biol Psychiatry. 1999; 45:1542-1552.

18. Bush G, Valera EM, Seidman L. Functional Neuroimaging of AttentionDeficit/Hyperactivity disorder: a Review and Suggested Future Directions. Biol Psychiatry. 2005; 57:1273-84.

19. Campbell SB, Ewing LJ. Follow-up of hard-to-manage preschoolers: adjustment at age 9 and predictors of continuing symptoms. J Child Psychol Psychiatry. 1990; 31(6):871-89.

20. Castellanos FX, Lee PP, Sharp W, Jeffries NO, Greenstein DK, Clasen LS, Blumenthal JD, James RS, Ebens CL, Walter JM, Zijdenbos A, Evans AC, Giedd JN, Rapoport JL. Developmental trajectories of brain volume abnormalities in children and adolescents with attentiondeficit/hyperactivity disorder. JAMA. 2002; 288(14):1740-8. 
21. Connors, C. K., Epstein, J., \& Marsh, J. Multi-modal treatment of ADHD (MTA): An alternative outcome analysis. J Acad Child and Adolesc Psychiatry. 2001; 40: 159-167.

22. Conselho Regional de Educação Física de São Paulo. Documento de intervenção profissional [internet]. 2010 Dez 03. Disponível em: http://www.crefsp.org.br/interna.asp?secao_id=37.

23. Conselho Regional de Fisioterapia e Terapia Ocupacional. Definição [internet]. 2010 Dez 03. Disponível em: www.crefito3.com.br.

24. Corazza TDM, Brusamarelo S, Cardoso FGC, Rosa Neto F. Validação de uma bateria de testes de organização espacial: análise da consistência interna. Temas sobre Desenvolvimento. 2010; 17:01-3.

25. Cormier E. Attention Deficit/Hyperactivity Disorder: A Review and Update. J Pediatr Nurs. 2008; 23 (5):345-57.

26. Desidério RCS, Miyazaki MCOS. Sugestões Práticas Transtorno de Déficit de Atenção / Hiperatividade (TDAH): Orientações para a Família. Rev Sem ABRAPEE. 2007; 11 (1): 165-178.

27. Di Nucci FP. Caracterização do Perfil Psicomotor de Crianças com o Transtorno de Déficit de Atenção e Hiperatividade [dissertação]. Campinas: Pontifícia Universidade Católica; 2007. 
28. Dickstein SG, Bannon K, Xavier CF, Milham MP. The neural correlates of attention deficit hyperactivity disorder: an ALE meta-analysis. J Child Psychol Psychiatry. 2006; 47:1051-62.

29. Dopheide JA, Pliszka SR. Attention-Deficit-Hyperactivity Disorder: An Update. Pharmacotherapy. 2009; 29 (6): 656-79.

30. DuPaul GJ, Power TJ, Anastopulos AD, Reid R. ADHD Rating Scale-IV: checklists, norms, and clinical interpretation. New York: Guilford Press; 1998.

31. Fayyad J, De Graaf R, Kessler R, Alonso J, Angermeyer M, Demyttenaere K, De Girolamo G, Haro JM, Karam EG, Lara C, Lépine JP, Ormel J, Posada-Villa J, Zaslavsky AM, Jin R. Cross-national prevalence and correlates of adult attention-deficit hyperactivity disorder. Br J Psychiatry. 2007; 190:402-9.

32. Faraone SV. Genetics of childhood disorders: XX. ADHD, Part 4: is ADHD genetically heterogeneous? J Am Acad Child Adolesc Psychiatry. 2000; 39 (11):1455-7.

33. Faraone SV, Khan SA. Candidate genes studies of attention-deficit/ hyperactivity disorder. J Clin Psychiatry. 2006; 67 (Supl 8): 13-20.

34. Faraone SV, Sergeant J, Gillberg C, Bierderman J. The Worldwide Prevalence of ADHD: Is It an American Condition? World Psychiatry. 2003; 2(2): 104-13. 
35. Faraone SV, Biederman J, Mick E. The age-dependent decline of attention deficit hyperactivity disorder: a meta-analysis of follow-up studies. Psychol Med. 2006; 36(2):159-65.

36. Fliers EA, Franke B, Lambregts-Rommelse NN, Altink ME, Buschgens CJ, Nijhuis-van der Sanden MW, Sergeant JA, Faraone SV, Buitelaar JK. Undertreatment of Motor Problems in Children with ADHD. Child Adolesc Ment Health. 2009 21;15 (2):85-90.

37. Gallahue DL, Ozmun JC. Compreendendo o desenvolvimento motor: bebês, crianças, adolescentes e adultos. 2a ed. São Paulo: Phorte; 2003.

38. Giedd JN, Blumenthal J, Molloy E, Castellanos FX. Brain imaging of attention deficit/hyperactivity disorder. Ann N Y Acad Sci. 2001; 931: 3349.

39. Gillberg C, Gillberg IC, Rasmussen P, Kadesjö B, Söderström H, Råstam M, Johnson M, Rothenberger $\mathrm{A}$, Niklasson L. Co-existing disorders in ADHD - implications for diagnosis and intervention. Eur Child Adolesc Psychiatry. 2004; 13 Suppl 1:180-92.

40. Gillberg C, Kadesjo B. Why bother about clumsiness? The implications of having developmental coordination disorder (DCD). Neural Plasticity. 2003; 10: 59-68. 
41. Grillo E, Silva RJM. Manifestações precoces dos transtornos do comportamento na criança e no adolescente.

42. Helene AF, Xavier GF. A construção da atenção a partir da memória. Rev Bras Psiquiatr. 2003; 25 (Suppl 2):12-20.

43. Hoffmann H. Der Struwwelpeter. Berlin: DBGM; 1854.

44. Holmes NP, Spence C. The body schema and the multisensory representation(s) of peripersonal space. Cogn Process. 2004; 5 (2):94105.

45. Kadesjo B, Gillberg C. The comorbidity of ADHD in the general population of Swedish school-age children. J Child Psychol Psychiatry. 2001; 42: 487-492.

46. Kandell ER, Schwartz JH, Jessell TM. Princípios de neurociência.4a ed. Barueri (SP): Manole, 2003.

47. Klimkeit EI, Mattingley JB, Sheppard DM, Lee P, Bradshaw JL. Motor Preparation, Motor Execution, Attention, and Executive Functions in Attention Deficit/Hyperactivity Disorder (ADHD). Child Neuropsychology $2005 ; 11: 153-173$

48. Knapp P, Johannpeter J, Lyszkowski LC, Rohde LA. Terapia CognitivoComportamental no TDAH: Manual do terapeuta. Porto Alegre: Artes Médicas; 2003. 
49. Kroes M, Kessels AGH, Kalff AC, Feron FJM, Vissers YLJ, Jolles J, Vles JSH. Quality of movement as predictor of ADHD: results from a prospective population study in 5- and 6-year old children. Dev Med \& Child Neurol. 2001; 44: 753-60.

50. Lent R. Cem bilhões de neurônios?: conceitos fundamentais de neurociência. 2a ed. São Paulo: Atheneu; 2010.

51. Louzã-Neto MR (org). TDAH ao longo da vida. Porto Alegre: Artmed; 2010.

52. Lundy-Ekman L. Neurociência: fundamentos para a reabilitação. 3a ed. Rio de Janeiro: Elsevier; 2008.

53. Mackie S, Shaw P, Lenroot R, Pierson R, Greenstein DK, Nugent TF, Sharp WS, Giedd JN, Rapoport JL. Cerebellar development and clinical outcome in attention deficit hyperactivity disorder. Am J Psychiatry. $2007 ; 164$ (4): 647-55.

54. Magalhaes LC, Missiuna C, Wong S. Terminology used in research reports of developmental coordination disorder. Dev Med Child Neurol. 2006; 48:937-941.

55. Magyary D, Brandt P. A decision tree and clinical paths for the assessment and management of children with ADHD. Issues in Mental Health Nursing. 2002; 23: 553-566. 
56. Makris N, Biederman J, Valera EM, Bush G, Kaiser J, Kennedy DN, Caviness VS, Faraone SV, Seidman LJ. Cortical Thinning of the Attention and Executive Function Networks in Adults with Attention Deficit/Hyperactivity Disorder. Cerebral Cortex. 2007; 17: 1364 -75.

57. Mattos P, Serra-Pinheiro MA, Rohde LA, Pinto D. Apresentação de uma versão em português para uso no Brasil do instrumento MTA-SNAP-IV de avaliação de sintomas de transtorno do déficit de atenção/hiperatividade e sintomas de transtorno desafiador e de oposição. Rev Psiquiatr. 2006; 28(3):290-7

58. Maria-Mengel MRS. "Vigilância do Desenvolvimento" em Programa de Saúde da Família: triagem para detecção de riscos para problemas de desenvolvimento em crianças [tese]. Ribeirão Preto: Universidade de São Paulo; 2007.

59. McLaughlin KA, Fox NA, Zeanah CH, Sheridan MA, Marshall P, Nelson CA. Delayed maturation in brain electrical activity partially explains the association between early environmental deprivation and symptoms of attention-deficit/hyperactivity disorder. Biol Psychiatry. 2010; 68(4):32936. Medina J, Rosa GKB, Marques I. Desenvolvimento da organização temporal de crianças com dificuldades de aprendizagem. Revista da Educação Física UEM Maringá. 2006; 17 (1): 107-116. 
60. Medina-Papst J, Marques I. Avaliação do desenvolvimento motor de crianças com dificuldades de aprendizagem. Rev Bras Cineantropom Desempenho Hum. 2010; 12(1): 36-42.

61. Mello LM, Poeta LS, Rosa Neto F. Aptidão motora em escolares com hiperatividade (TDAH) do ensino fundamental de Florianópolis, SC. Motriz. 2003; 9 (1):S109-200.

62. Mick E, Faraone SV. Genetics of Attention Deficit Hyperactivity Disorder. Child Adolesc Psychiatric Clin N Am. 2008; 17: 261-84.

63. Miyahara M, Piek J, Barret N. Accuracy of drawing in a dual-task and resistance-to-distraction study: Motor or attention deficit? Human Movement Science. 2006; 25 (1): 100-9.

64. Organização Mundial da Saúde. Classificação de transtornos mentais e de comportamento da CID-10: descrições clínicas e diretrizes diagnósticas. Porto Alegre: Artes Médicas; 1993.

65. Organização Pan-Americana da Saúde. Manual para vigilância do desenvolvimento infantil no contexto da AIDPI. Washington (D.C); 2005.

66. Ortega F, Barros D, Caliman L, Itaborahy C, Junqueira L, Ferreira CP. A ritalina no Brasil: produções, discursos e práticas. Interface Comunic. Saúde Educ. 2010, 14 (34): 499-510. 
67. Pastura G, Mattos $P$, Araújo APQC. Prevalência do transtorno de déficit de atenção e hiperatividade e suas comorbidades em uma amostra de escolares. Arq Neuropsiquiatr. 2007; 65(4-A):1078-83.

68. Pereira HS, Araújo APQC, Mattos P. Transtorno de déficit de atenção e hiperatividade (TDAH): aspectos relacionados à comorbidade com distúrbios da atividade motora. Rev Bras Saúde Matern Infant. 2005; 5 (4):391-402.

69. Piek JP, Dyck MJ. Sensory-motor deficits in children with developmental coordination disorder, attention deficit hyperactivity disorder and autistic disorder. Human Mov Science. 2004; 23: 475-88.

70. Pitcher TM, Piek JP, Hay DA. Fine and gross motor ability in males with ADHD. Dev Med \& Child Neurol. 2003; 45: 525-35.

71. Poeta LS, Rosa Neto F. Estudo epidemiológico dos sintomas do transtorno de déficit de atenção / hiperatividade e transtornos comportamentais em escolares da rede pública de Florianópolis usando a EDAH. Rev Bras Psiquiatr. 2004; 28 (3):150-5.

72. Poeta LS, Rosa Neto F. Evaluación motora en escolares con indicadores del trastorno por déficit de atención/hiperactividad. Rev Neurol. 2007; 44 (3): 146-9, 2007. 
73. Polanczyk G, Lima MS, Horta BL, Biederman J, Rohde LA. The Worldwide Prevalence of ADHD: A Systematic Review and Metaregression Analysis. Am J Psychiatry. 2007; 164:942-948.

74. Polatajko HJ, Cantin N. Developmental coordination disorder (dyspraxia): An overview of the state of the art. Seminars in Pediatric Neurology. 2005; 12:250-258.

75. Racine MB, Majnemer A, Shevell M, Snider L. Handwriting performance in children with attention deficit hyperactivity disorder (ADHD). $J$ Child Neurol. 2008; 23(4):399-406.

76. Raberger $\mathrm{T}$, Wimmer $\mathrm{H}$. On the automaticity/cerebellar deficit hypothesis of dyslexia: balancing and continuous rapid naming in dyslexic and ADHD children. Neuropsychologia. 2003; 41 (11): 1493-7.

77. Raynor AJ Strength, Power and co-activation in children with developmental coordination disorder. Dev Med Child Neurol. 2001; 43: $676-84$.

78. Remschmidt H; Global ADHD Working Group. Global consensus on ADHD/HKD. Eur Child Adolesc Psychiatry. 2005;14 (3):127-37.

79. Renner W, Anderle FG. Venturesomeness and extraversion as correlates of juvenile drivers' traffic violations. Accid Anal Prev. 2000; 32: 673-78. 
80. Rohde LA, Biederman J, Busnello EA, Zimmermann H, Schimitz $M$, Martins S, Tramontina S. AHDD in a school sample of brazilian adolescents: a study of prevalence, comorbid conditions, and impairments. J Am Acad Child Adolescent Psyquiatry. 1999; 38 (6): 716-22.

81. Rohde LA, Barbosa G, Tramontina S; Polanczy G. Transtorno de déficit de atenção/hiperatividade. Rev Bras Psiquiatr. 2000; 22 (Supl. II): 0711.

82. Rohde LA, Halpern R. Transtorno de déficit de atenção/hiperatividade: atualização. J Ped. 2004; 80 (Supl 2): 61-70.

83. Roman T, Rohde LA, Hutz MH. A role for neurotransmission and neurodevelopment in attention-deficit/hyperactivity disorder. Genome Med. 2009; 19, 1(11):107.

84. Rommelse NNJ, Altink ME, Oosterlaan J, Buschgens CJM, Buitelaar J, Sonneville LMJ, Sergeant JA. Motor control in children with ADHD and non-affected siblings: deficits most pronounced using the left hand. Journal of Child Psychology and Psychiatry. 2007; 48 (11): 1071-79.

85. Rosa Neto F. Manual de Avaliação Motora. Porto Alegre: Artmed, 2002.

86. Rosa Neto F, Caon G, Bissani C, Silva C, Sousa M, Silva E. Características neuropsicomotoras de crianças de alto risco neurológico 
atendidas em um programa de follow up. Pediatria Moderna. 2005; 42(2): 79-85.

87. Rosa Neto F, Santos APM, Xavier R, Amaro KN. A Importância da Avaliação Motora em escolares - Análise da confiabilidade da escala motora EDM. Rev Bras Cineantropom Desempenho Hum. 2010a; 12: $422-7$.

88. Rosa Neto F, Santos APM, Weiss SLI, Amaro KN. Análise da consistência interna dos testes de motricidade fina da EDM - Escala de Desenvolvimento Motor. Revista da Educação Física/UEM. 2010b; 21: $191-7$.

89. Santos SMP, Cruz DRM. Brinquedo e Infância: uma guia para pais e educadores em creche. Editora Vozes; 2001.

90. Schmitz M, Denardin D, Laufer Silva T, Pianca T, Hutz MH, Faraone S, Rohde LA. Smoking during pregnancy and attention-deficit/hyperactivity disorder, predominantly inattentive type: a case-control study. J Am Acad Child Adolesc Psychiatry. 2006; 45 (11): 1338-45.

91. Seidman LJ, Valera EM, Makris N, Monuteaux MC, Boriel DL, Kelkar K, Kennedy DN, Caviness VS, Bush G, Aleardi M, Faraone SV, Biederman J. Dorsolateral prefrontal and anterior cingulate cortex volumetric abnormalities in adults with attention-deficit/hyperactivity disorder identified by magnetic resonance imaging. Biol Psychiatry. 2006; 60 (10): $1071-80$. 
92. Sergeant JA, Guerts H, Oosterlaan J. How specific is a deficit of executive functioning for attention-deficit/ hyperactivity disorder? Behavioural Brain Research, v.130, n.1-2, p.3-28, 2002.

93. Silveira CRA, Menuchi MRTP, Simoes CSA, CaetanoMJD, Gobbi LTB. Validade de construção em testes de equilíbrio: ordenação cronológica na apresentação das tarefas. Rev Bras Cineantropom Desempenho Hum. 2006; 8(3):66-72.

94. Shaw P, Eckstrand K, Sharp W, Blumenthal J, Lerch JP, Greenstein D, Clasen I, Evans A, Giedd J, Rapoport JL. Attention-deficit/hyperactivity disorder is characterized by a delay in cortical maturation. PNAS. 2007; 104 (49): 196949-54.

95. Spencer T, Biederman J, Wilens T. Pharmacotherapy of attention deficit hyperactivity disorder. Child Adolesc Psychiatr Clin North Am. 2000; 9:77-97.

96. St Sauver JL, Barbaresi WJ, Katusic SK, Colligan RC, Weaver AL, Jacobsen SJ. Early life risk factors for attention-deficit/hyperactivity disorder: a population-based cohort study. Mayo Clin Proc. 2004; 79 (9):1124-31.

97. Stray LL, Stray T, Iversen S, Ruud A, Ellertsen B, Tonnessen E. The Motor Function Neurological Assessment (MFNU) as an indicator of 
motor function problems in boys with ADHD. Behavioral and Brain Functions. 2009; 5 (22): 01-13.

98. Suzuki S, Gugelmin MRG, Soares AV. O equilíbrio estático em crianças em idade escolar com transtorno de déficit de atenção / hiperatividade. Fisiot em Mov 2005; 18 (3): 49-54.

99. Steer CR. Managing attention deficit/hyperactivity disorder: unmet needs and future directions. Arch Dis Child. 2005; 90:19-25.

100. Still GF. Some abnormal psychical conditions in childhood. Lancet. 1902;1:1008.

101. Swanson JM. School-based assessments and interventions for $A D D$ students. Irvine, CA: K. C. Publishing; 1992.

102. Swanson JM, Kraemer HC, Hinshaw SP. Clinical relevance of primary findings of the MTA: Success rates based on severity of ADHD and ODD symptoms at the end of treatment. Journal of the Academy of Child and Adolescent. J Acad Child and Adolesc Psychiatry. 2001; 40, 168-179.

103. Swanson JM, Lerner MA, Gupta S, Shoulson I, Wigal S. Development of a new once-a-day formulation of methylphenidate for the treatment of ADHD. Arch Gen Psychiatry. 2003; 60: 204-11.

104. Teng CT, Demetrio FN. Psicofarmacologia aplicada: manejo prático dos Transtornos Mentais. Atheneu. 2007:185-209. 
105. The MTA Cooperative Group Multimodal Treatment Study of Children with ADHD. A 14-month Randomized Clinical Trial of Treatment Strategies for Attention Deficit/hyperactivity Disorder. Arch Gen Psychiatry. 1999; 56: 11073-86.

106. Toniolo CS, Santos LCA, Lourenceti MD, Padula NAMR, Capellini AS. Caracterização do desempenho motor em escolares com transtorno de déficit de atenção com hiperatividade. Rev Psicopedagogia. 2009; 26 (79): $33-40$.

107. Trojan S, Langmeier M, Maresová D, Mourek J, Pokorný J. Plasticity of the brain in neuroontogenesis. Prague Med Rep. 2004; 105(2):97110.

108. Tseng MH, Henderson A, CHOW SMK, YAOG. Relationship between motor proficiency, attention, impulse, and activity in children with ADHD. Dev Med \& Child Neurol. 2004; 46: 381-8.

109. Valera EM, Faraone SV, Biederman J, Poldrack RA, Seidman LJ. Functional neuroanatomy of working memory in adults with attention deficit/ hyperactivity disorder. Biol Psychiatry. 2005; 57:439-447.

110. Valera EM, Faraone SV, Murrayc KE, Seidman LJ. Meta-Analysis of Structural Imaging Findings in Attention-Deficit/Hyperactivity Disorder. Biol Psychiatry. 2007; 6 (12): 1361-9. 
111. Valeski A, Coelho BLP, Rodrigues MC. Transtorno de déficit de atenção/hiperatividade: tratamento fisioterapêutico com abordagem ludoterapêutica. Fisioterapia Brasil. 2004; 5 (1): 66-72.

112. Vidarte JA, Ezquerro M, Giráldez MA. Perfil psicomotor de niños de 5 a 12 años diagnosticados clínicamente de trastorno por déficit de atención/hiperactividad en Colombia. Rev Neurol. 2009; 49 (2): 69-75.

113. Vieira MEB, Ribeiro FV, Formiga CKMR. Principais instrumentos de avaliação do desenvolvimento da criança de zero a dois anos de idade. Rev Movimenta. 2009; 2(1): 23-31.

114. Visser J. Developmental coordination disorder: a review of research on subtypes and comorbidities. Human Movement Science. 2003; 22:479-493.

115. Visser SN, Lesesne CA. Mental Health in the United States: Prevalence of diagnosis and medication treatment for Attention Defficit / Hiperactivity Disorder. United States: 2003.

116. Watemberg N, Waiserberg N, Zuk L, Lerman-Sagie T. Developmental coordination disorder in children with attention-deficit-hyperactivity disorder and physical therapy intervention. Dev Med Child Neurol. 2007; 49(12):920-5.

117. Willcutt EG, Doyle AE, Nigg JT, Faraone SV, Pennington BF. Validity of the executive function theory of attention-deficit/ hyperactivity 
disorder: a meta-analytic review. Biological Psychiatry. 2005; 57 (11): 1336-1346.

118. Zomignani AP, Zambelli HJL, Antonio MARGM. Desenvolvimento cerebral em recém-nascidos prematuros. Rev Paul Pediatr. 2009; 27(2):198-203. 